UNIVERSIDADE ESTADUAL PAULISTA "JULIO DE MESQUITA FILHO"

FACULDADE DE CIÊNCIAS AGRONÔMICAS

CÂMPUS DE BOTUCATU

\title{
SISTEMA DE INFORMAÇÃO PARA O CONTROLE DOS RECURSOS ENERGÉTICOS NO MEIO RURAL
}

\section{RENATO CORREIA DE BARROS}

Tese apresentada à Faculdade de Ciências Agronômicas da UNESP - Campus de Botucatu, para obtenção do título de Doutor em Agronomia (Energia na Agricultura).

BOTUCATU - SP

Outubro - 2010 


\section{SISTEMA DE INFORMAÇÃO PARA O CONTROLE DOS RECURSOS ENERGÉTICOS NO MEIO RURAL}

\section{RENATO CORREIA DE BARROS}

Orientador: Prof. Dr. Angelo Cataneo

Tese apresentada à Faculdade de Ciências Agronômicas da UNESP - Campus de Botucatu, para obtenção do título de Doutor em Agronomia (Energia na Agricultura). 
FICHA CATALOGRÁEICA ELABORADA PELA SEC̄̃O TECNICA DE AQUISIC̄̃O E IRATAMENTO DA INFORMAÇĀO - SERVIÇO TECNICO DE BIBLIOTECA E DOCUMENTAÇĀO - UNESP - FCA - LAGEADO - BOTUCATU (SP)

Barros, Renato Correia de, $1975-$
B277s Sistema de informaçăo para o controle dos recursos energéticos no meio rural / Renato Correia de Barros. Botucatu : $[\mathbf{s}, \mathrm{n}],$.

xili, $90 \mathrm{f}$. : il. color., grafs., tabs, fots. color,

Tese (Doutorado) - Universidade Estadual Paulista, Faculdade de Ciēncias Agronómicas, Botucatu, 2010

Orientador: Angelo Cataneo

Inclui bibliografia

1. Sistema de informaçāo. 2. Matríz energètica. 3. Balanço energético, I, Cataneo, Angelo. II. Universidade Estadual Paulista "Júlio de Mesquita Eilho" (Campus de Botucatu). Faculdade de Ciếncias Agronômicas. III. Título. 


\section{UNIVERSIDADE ESTADUAL PAULISTA "JÚLIO DE MESQUTTA FILHO" FACULDADE DE CIÊNCIAS AGRONÔMICAS CAMPUS DE BOTUCATU CERTIFICADO dE APROVAÇÃO}

\section{TiTILO: "SISTEMA DE INFORMAÇÃO PARA O CONTROLE DOS RECURSOS}

ENERGÉTICOS NO MEIO RURAL"

ALUNO: RENATO CORREIA DE BARROS

ORIENTADOR: PROF, DR, ANGELO CATANEO

Aprovido pela Comissão Examinadora

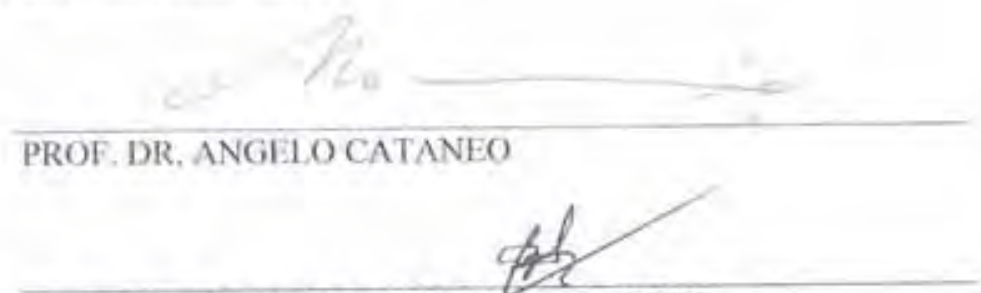

PROF. DR. ZACARIAS XAVIEK DE BARROS

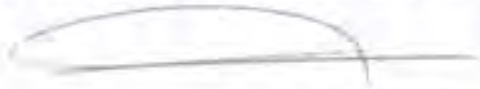

PROF. DR. SERGIO A LUNARDELLI FURCHI

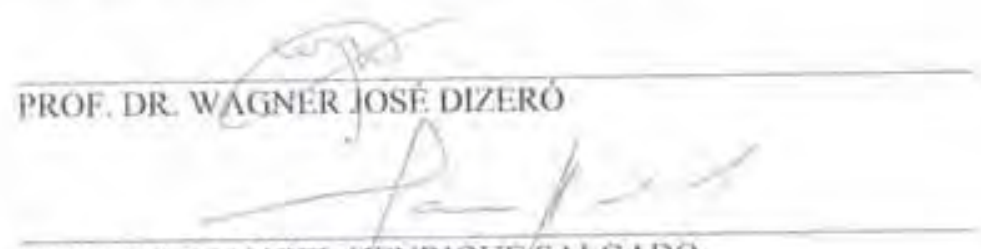

PROF. DR. MANOEL HENRIQUE SALGADO

Data da Realização: 25 de outubro de 2010 


\section{AGRADECIMENTOS}

Primeiramente a Deus, por toda a sua bondade e auxilio nos momentos mais difíceis, que sem ELE, tudo parecia impossível.

Ao meu orientador o prof. Dr. Angelo Cataneo, por ser um exemplo de conduta e caráter a ser seguido e por todo o auxilio e paciência durante todo este período.

Aos professores do programa que me acompanharam durante o desenvolvimento deste projeto e ajudaram no amadurecimento das ideias e que me servem de espelho.

Ao Prof. Dr. Osmar de Carvalho Bueno por suas contribuições e ideias que ajudaram na elaboração desta tese.

Aos meus amigos do programa de pós-graduação por sua paciência e compreensão.

Aos meus pais, por mostraram-me o caráter e a dedicação que um homem deve ter e pelo modelo familiar e de conduta que sempre tiveram. Amo muito vocês.

Ao meu irmão pelas horas de conversa e alivio. É muito bom ter você por perto.

À meu ex-aluno Julio Catardo, por sua ajuda em Java, que sem ele as coisas seriam ainda mais difíceis. Vi em você um novo professor.

À dois grandes amigos, Mauro e Aldo, por toda a ajuda em momentos difíceis.

A Thays Vicuña e família, pelo auxilio nos momentos de angústia. Obrigado por tudo.

A minha família por toda a ajuda.

A todos os meus amigos, pelos momentos felizes que passamos juntos.

Ao programa de Pós-Graduação em Energia na Agricultura pela oportunidade de realização deste curso. 


\section{SUMÁRIO}

Página

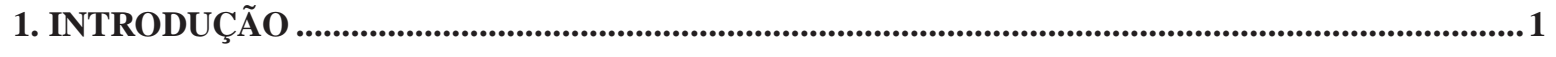

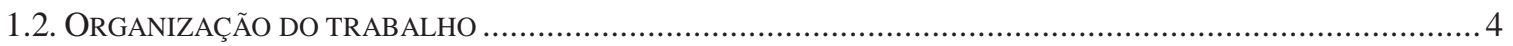

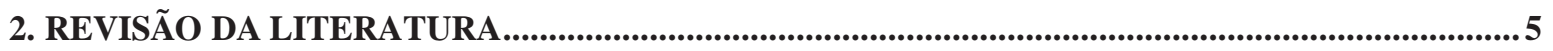

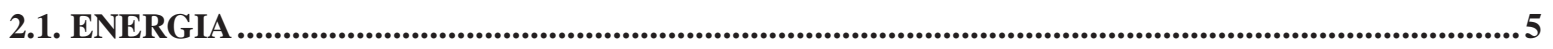

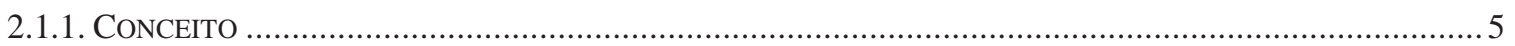

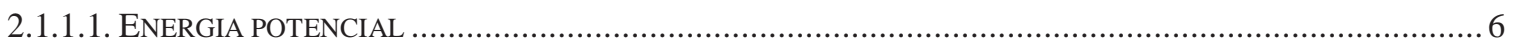

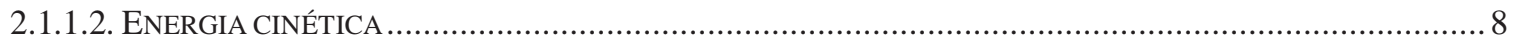

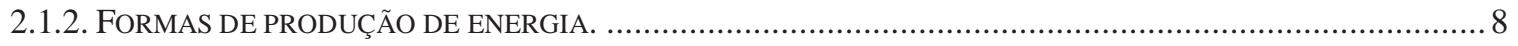

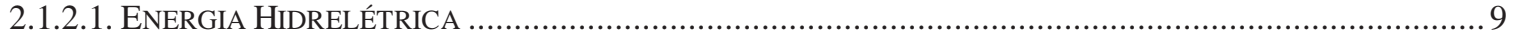

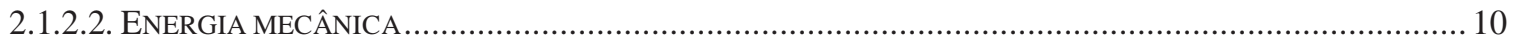

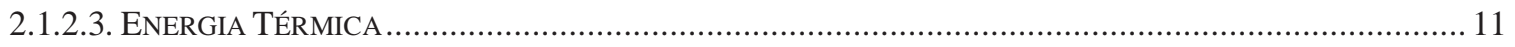

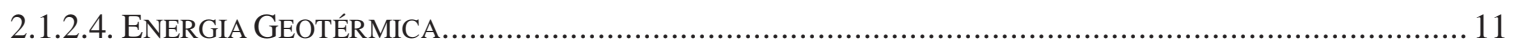

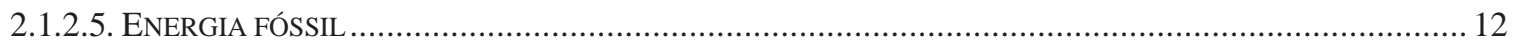

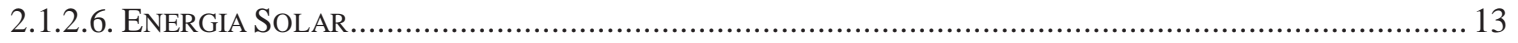

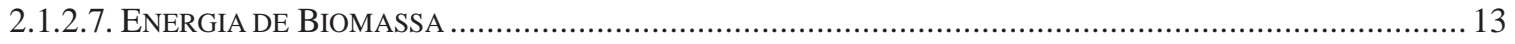

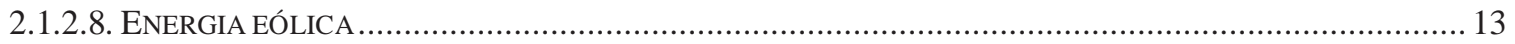

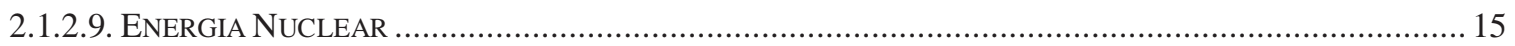

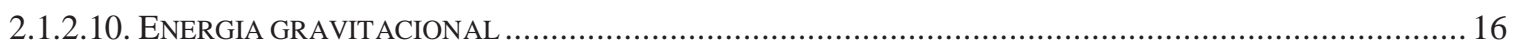

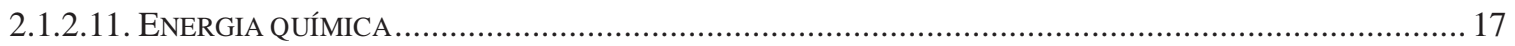

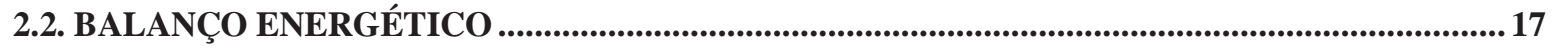

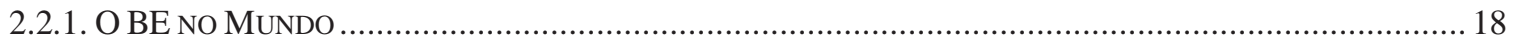

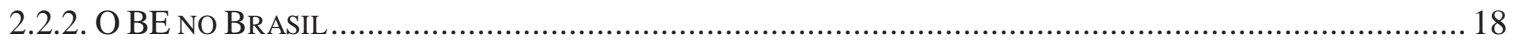

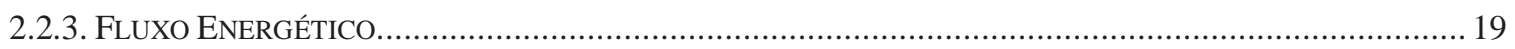

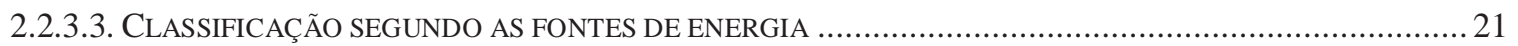

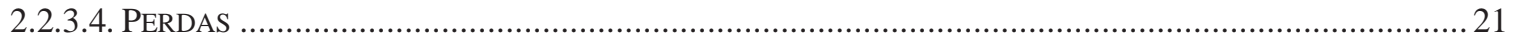

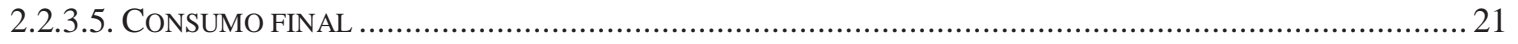

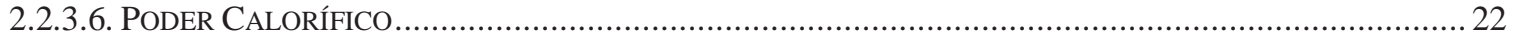

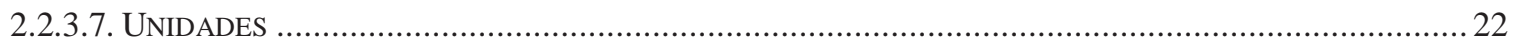

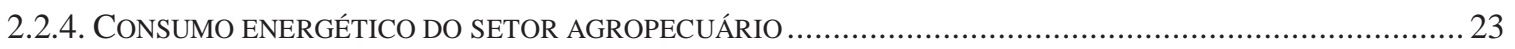

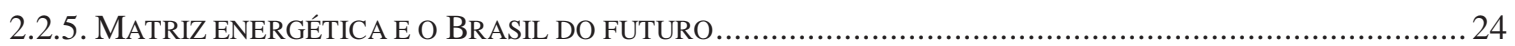

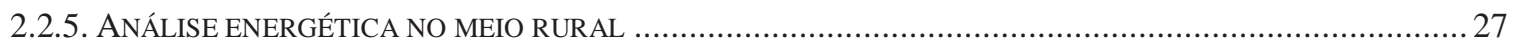

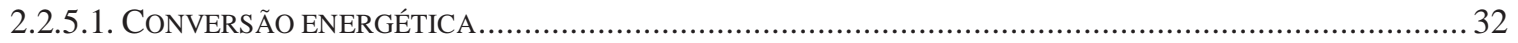

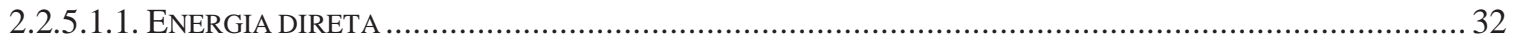

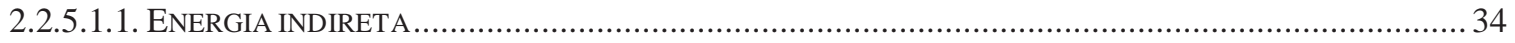

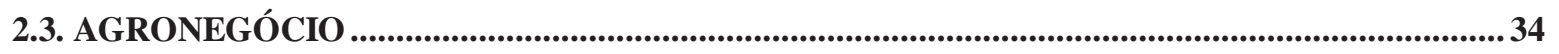

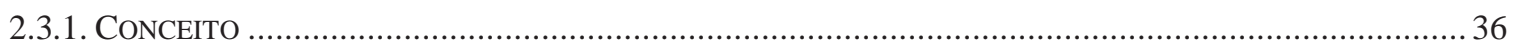

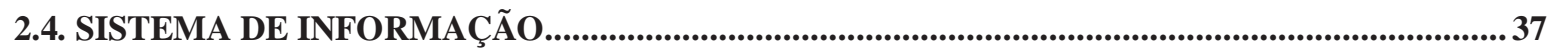

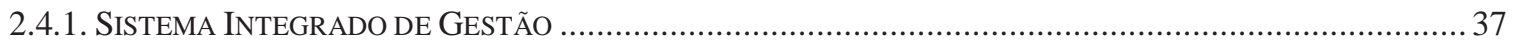

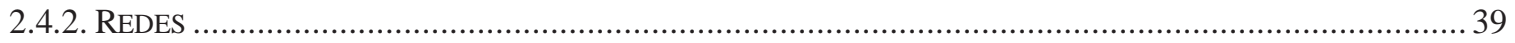

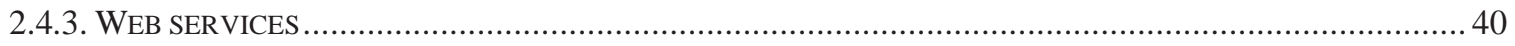

2.5. FERRAMENTAS DE DESENVOLVIMENTO ........................................................................ 41

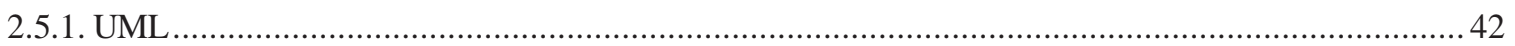

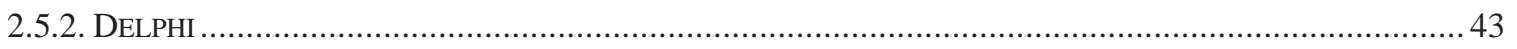

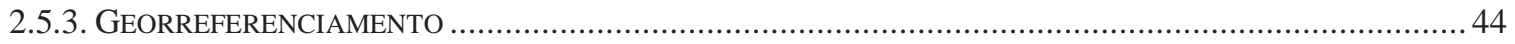




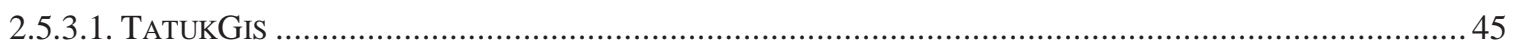

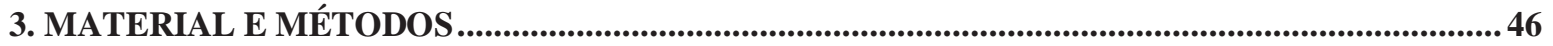

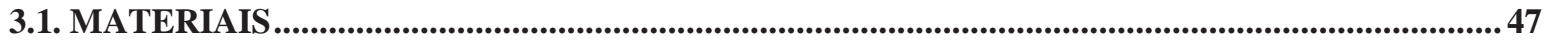

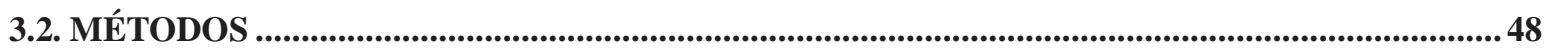

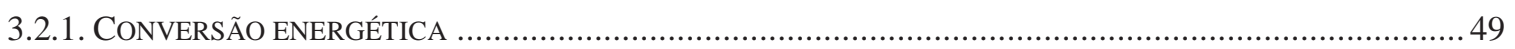

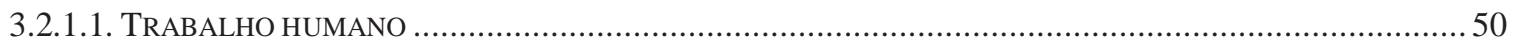

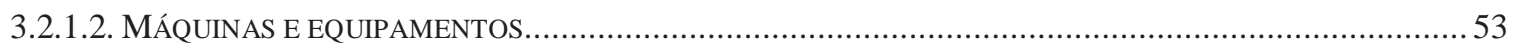

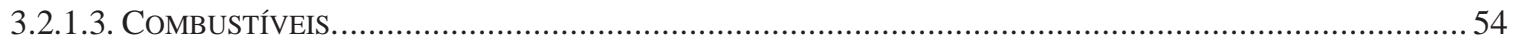

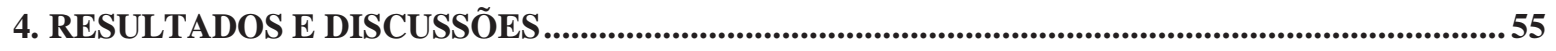

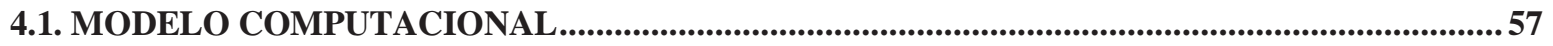

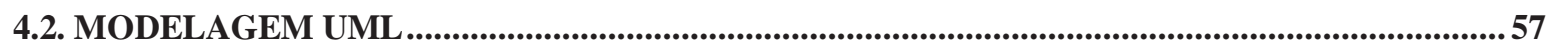

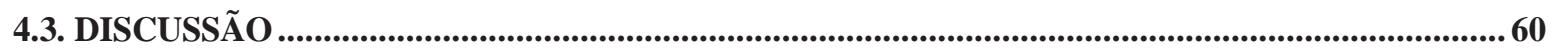

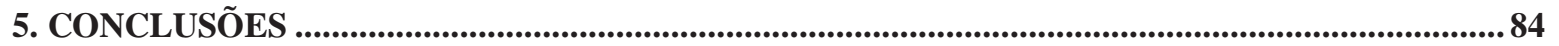

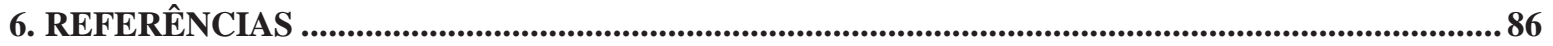




\section{LISTA DE FIGURAS}

Página

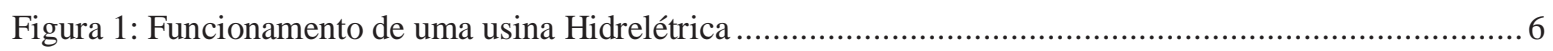

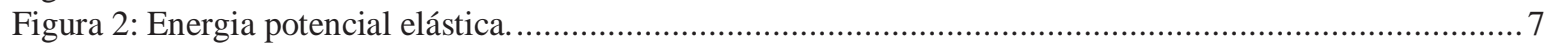

Figura 3: Esquema de funcionamento de uma hidrelétrica. ..................................................................... 9

Figura 4: Usina hidrelétrica de Itaipu, na fronteira do Brasil com o Paraguai............................................... 10

Figura 5: Transformação da energia térmica em elétrica. ............................................................................. 11

Figura 6: Usina geotérmica na Islândia............................................................................................ 12

Figura 7: Aerogerador Enercon E-66 - Alemanha....................................................................................... 14

Figura 8: Diagrama do reator de uma Usina Nuclear (Energia, 2010)....................................................... 15

Figura 9: Caixa de concreto por onde, no sobe e desce das marés, passa a água do mar cuja energia é aproveitada na geração de eletricidade (Energia,2010)................................................................... 16

Figura 10: Consumo energético da agricultura em 103 TEP.....................................................................23

Figura 11: Composição do consumo energético na agricultura ..................................................................... 24

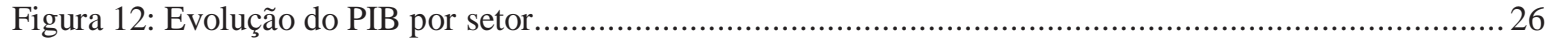

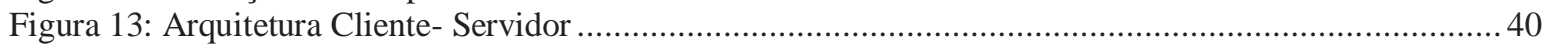

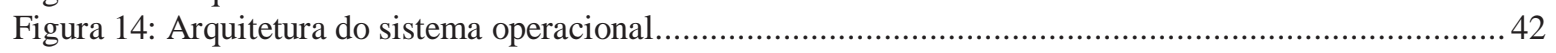

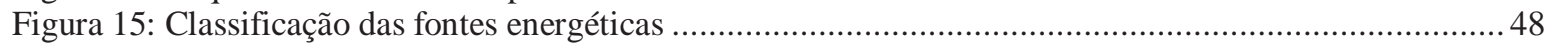

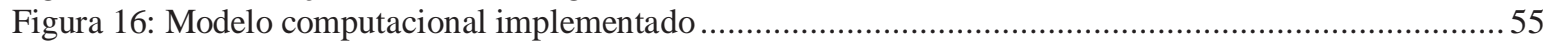

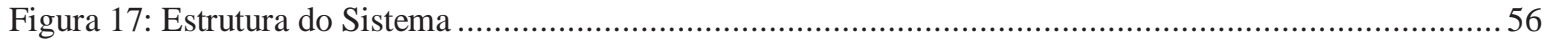

Figura 18: Diagrama de Classes do software cliente ….............................................................................. 58

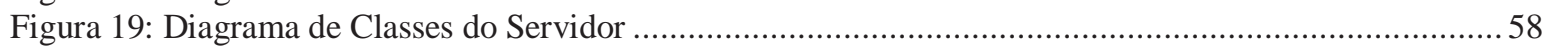

Figura 20: Cadastro padrão - Campo que será executado a busca .................................................................. 60

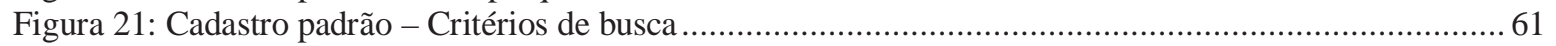

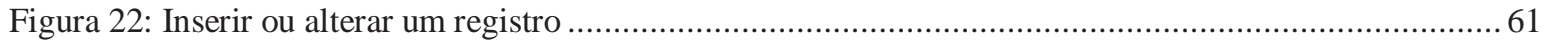

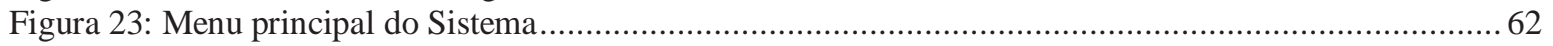

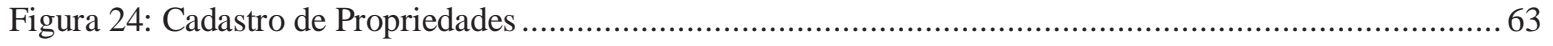

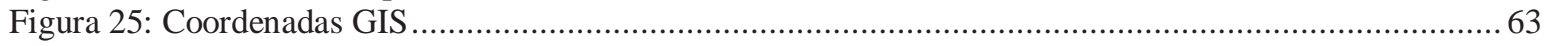

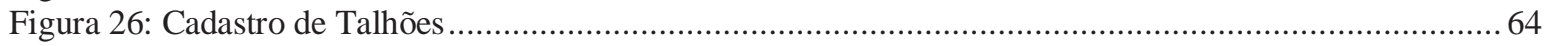

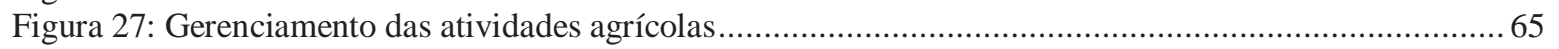

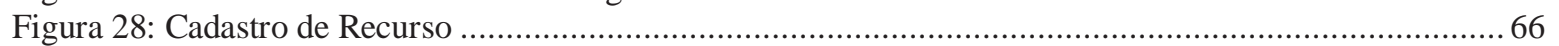

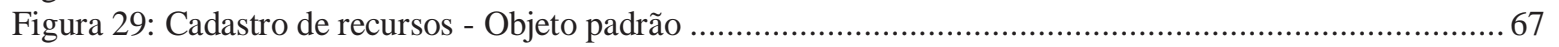

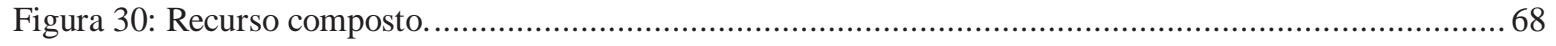

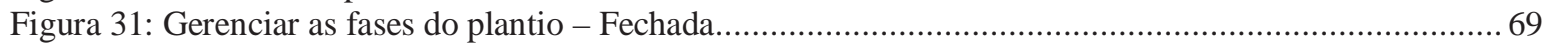

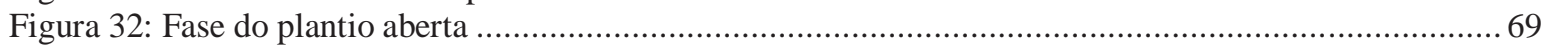

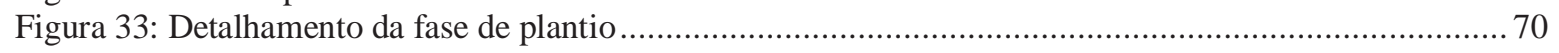

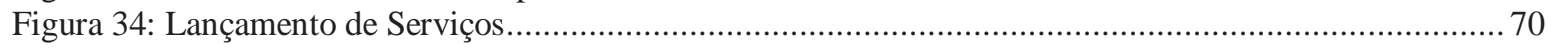

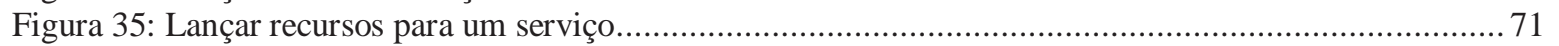

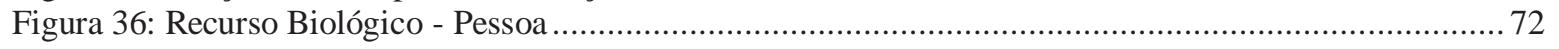

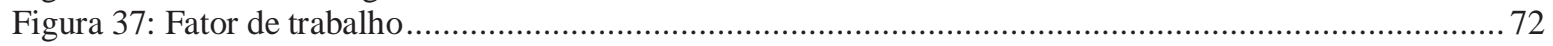

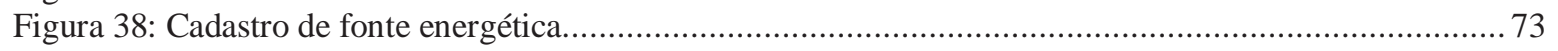

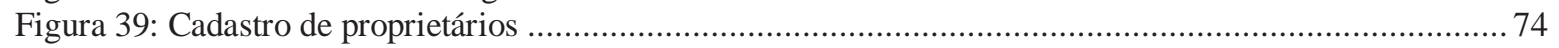

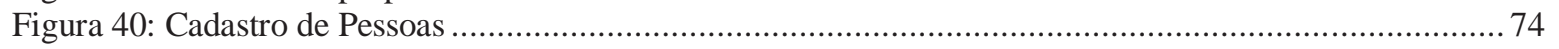

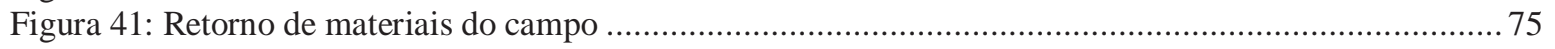

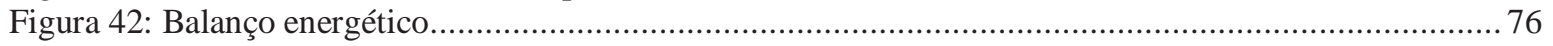

Figura 43: Dispêndio energético por atividade de plantio......................................................................... 77

Figura 44: Analise de gastos energéticos por cultura............................................................................... 78

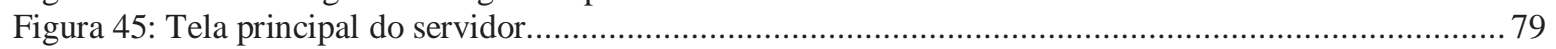

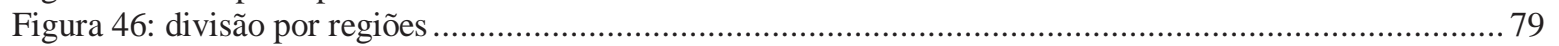

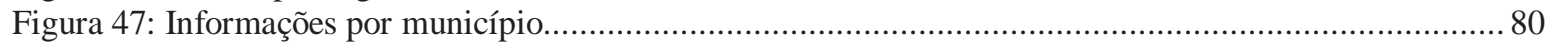

Figura 48: Informações detalhadas sobre uma localidade ...................................................................... 81

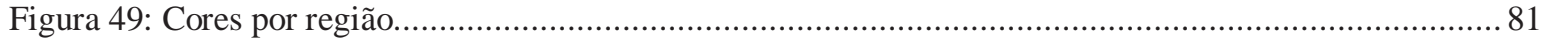

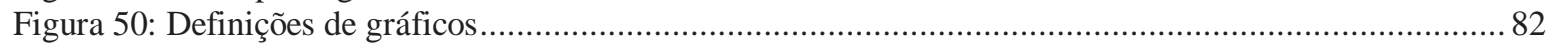




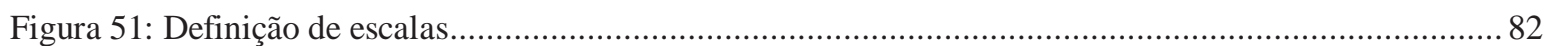

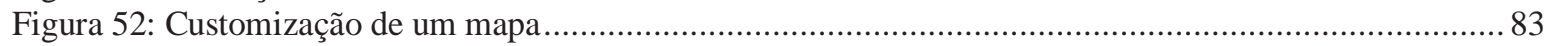




\section{LISTA DE TABELAS}

Página

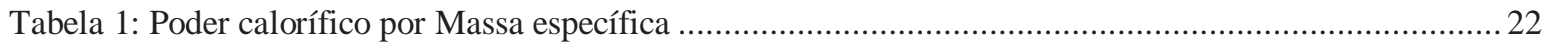

Tabela 2: Produto Interno Bruto por Setor (em US\$ bilhões de 2005). ........................................................ 25

Tabela 3: Estrutura de consumo energético no setor agropecuário por fonte em 2030 (fonte: BEN 2030)...... 27

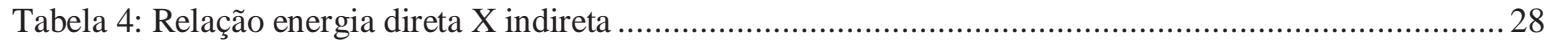

Tabela 5: Classificação do esforço físico diário. Adaptação do trabalho de Seixas (1991)............................. 33

Tabela 6: Dispêndio calórico dos defensivos agrícolas segundo Mello(2000) ............................................. 33

Tabela 7: Dispêndio Energético de fertilizantes e corretivos segundo Pimentel(1980b) ................................ 34

Tabela 8: Fator de Trabalho .................................................................................................................. 52

Tabela 9: Exemplo de calculo de gasto energético .................................................................................... 52

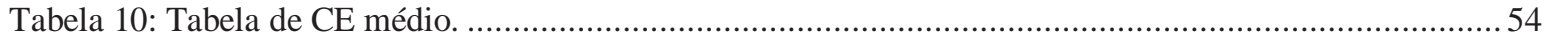

Tabela 11: Coeficiente Energético dos derivados de petróleo .....................................................................54 


\section{LISTA DE SIGLAS}

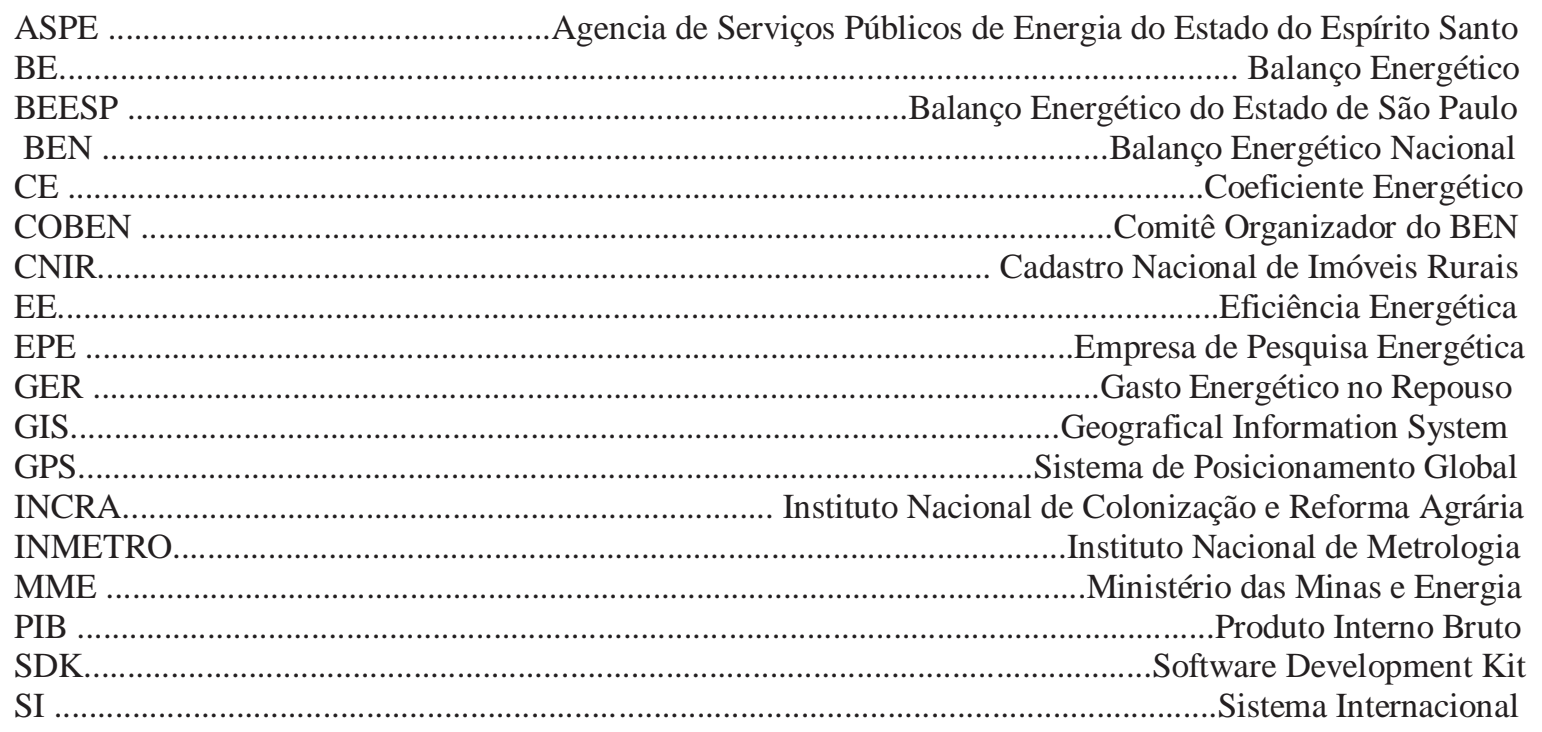




\section{LISTA DE ABREVIATURAS E DE SÍMBOLOS}

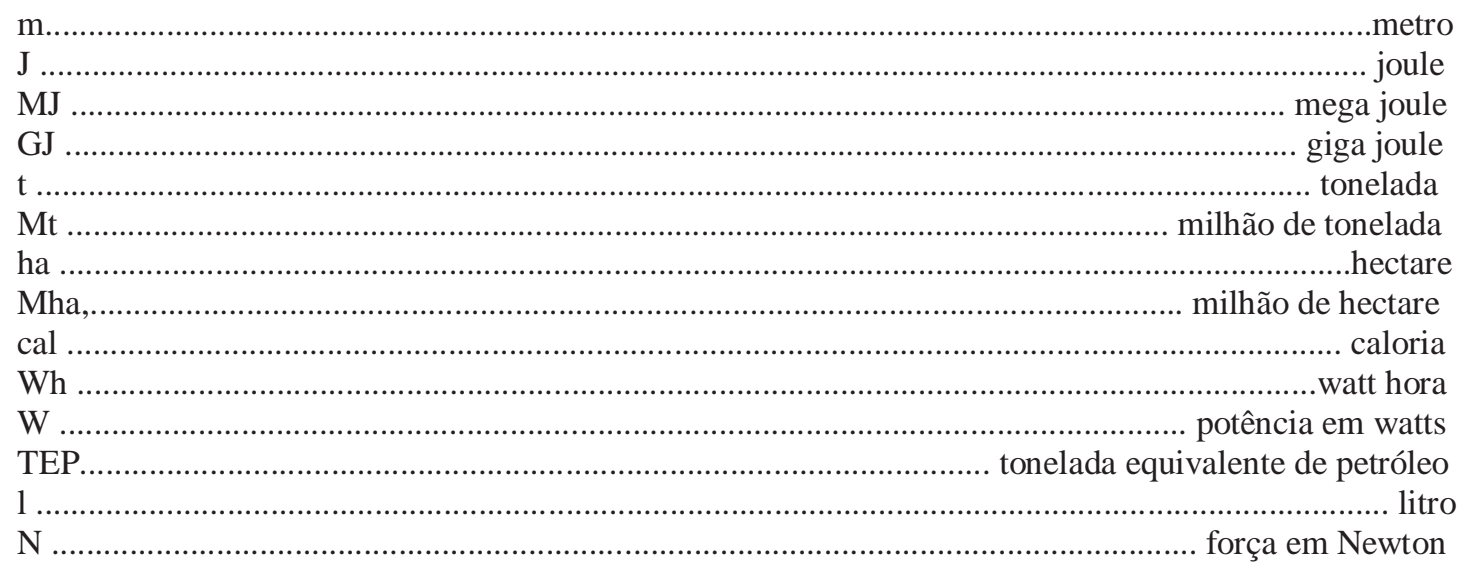




\section{RESUMO}

Com o fenômeno da globalização e da unificação dos mercados, novas oportunidades de negócio surgiram, exigindo dos produtores o incremento da qualidade dos serviços e o controle preciso das operações, reduzindo o custo operacional. Neste novo senário, as propriedades rurais estão passando por grandes mudanças, transformando-se em verdadeiras empresas rurais. Cada vez mais este novo modelo econômico prima pela qualidade e pela sustentabilidade do agronegócio. Para tal, é necessário um sistema que auxilie o produtor rural a administrar o seu negócio. A maioria dos estudos estão focados em levantamento financeiro e esquecem que é essencial para a agricultura definir o Balanço Energético e determinar a sua eficiência. Vários trabalhos propostos comparam duas formas produtivas em uma determinada região, mas não existe um estudo em nível nacional. O presente trabalho propõe um modelo de sistema de informação que abrange a parte energética do agronegócio, bem como o envio destas informações para uma base centralizada, a fim de obter o modelo energético rural brasileiro. Com isto, será possível determinar o Balanço Energético e as formas mais eficientes de plantio no agronegócio. O sistema proposto é dividido em dois módulos. O primeiro é voltado aos pequenos produtores rurais, no intuito de ajuda-los na administração rural, disponibilizando relatórios gerencias para que o produtor conheça o desempenho energético do sistema agrícola implantado, podendo maximizar os resultados energéticos e melhorar a eficiência da produção. O segundo módulo é composto de um software de analise de dados, recebendo os dados enviados pelos produtores e construindo uma base nacional de informação a respeito dos resultados energéticos, podendo comparar a eficiência dos sistemas de plantio em determinadas regiões ou realizar uma análise histórica, comparando o desempenho ao longo dos anos.

Palavras-chave: Sistema de Informação; Matriz energética; Balanço energético; 
INFORMATION SYSTEM FOR CONTROL OF ENERGY RESOURCES IN RURAL

AREAS. Botucatu, 2010.

Tese (doutorado em Agronomia / Energia na agricultura) - Faculdade de Ciência Agronômicas, Universidade Estadual Paulista

Author: RENATO CORREIA DE BARROS

Adviser: DR. ANGELO CATANEO

\section{SUMMARY}

With the phenomenon of globalization and the unification of markets, new business opportunities have emerged, requiring producers to increase service quality and precise control of operations, reducing operating cost. In this new senary, farms are undergoing major changes, transforming themselves into true rural businesses. Increasingly, this new economic model strives for quality and sustainability of agribusiness. For such a system is needed to assist the farmer to manage your business. Most studies are focused on raising financial and forget that agriculture is essential to define the energy balance and determine its efficiency. Several studies comparing two proposed forms of production in a given region, but there is a nationwide study. This paper proposes a model of information system that covers the energy part of agribusiness, as well as sending this information to a centralized database in order to get the Brazilian rural energy model. With this, you can determine the energy balance and more efficient ways of planting in agribusiness. The proposed system is divided into two modules. The first is geared to small farmers in order to aid them in farm management, providing management reports for the producer to meet the energy performance of the agricultural system in place, the results can maximize energy and improve production efficiency. The second module consists of a software data analysis, receiving the data sent by the producers and building a national information regarding the results of energy and can compare the efficiency of cropping systems in certain regions or making a historical analysis, comparing performance over the years.

Keywords: Information Systems; Matrix Energy; Energy Balance 


\section{INTRODUÇÃO}

Com a globalização e a unificação dos mercados, novas oportunidades de negócios surgiram, principalmente no meio rural. É fato que com a crescente qualidade dos serviços, o pequeno produtor rural não consegue concorrer nesse mercado sem o controle preciso de suas operações e custos, visando obter produtos mais baratos e com melhor qualidade.

Tendo em vista essa necessidade de produção, muitos produtores transformaram suas propriedades em um "agro-business", isto é, verdadeiras empresas rurais, onde a informação é fator de sucesso para o negócio. Assim, a propriedade rural passou por uma transformação e chegou ao status de empresa.

A informação vem se transformando em um recurso fundamental em qualquer organização, uma vez que se vive na era da informação. Logo, as empresas sobrevivem ou não a esta realidade. Isso depende da habilidade que elas têm para processar dados, transformá-los em informações, distribuí-los adequadamente e usá-los com rapidez para tomar decisões.

Neste cenário, a comunicação, que é basicamente o processo de troca de informações, tem um papel decisivo.

O valor da informação é um conceito muito relativo, pois nem todas as informações apresentam a mesma importância para uma decisão e, por melhor que esta seja, se não for comunicada às pessoas interessadas em forma e conteúdo adequados, perde todo seu valor. A informação pode ser infinitamente reutilizável, não se deteriora nem se deprecia e seu valor é determinado exclusivamente pelo usuário, já que não possui o mesmo valor para todos os setores do negócio.

A informação não se limita a dados coletados. Para que estes se transformem em informações é necessário que sejam organizados e ordenados de forma a se tornarem úteis. 
Portanto, quando os dados que estão armazenados na base de dados de uma organização são transformados em informação, eles possuem um valor inestimável, uma vez que são as chaves para se obter vantagem competitiva ou um diferencial ou até mesmo os dois.

A importância de informação e os meios necessários para obtê-las são tão importantes para a organização que muitas a consideram como um bem precioso e até como parte de seu ativo.

"A informação é um ativo que, como qualquer outro ativo importante para os negócios, tem um valor para a organização e consequentemente necessita ser adequadamente protegida" - KATZAM (apud LAUREANO, 2005).

Portanto, as empresas sempre estão em busca de informações, uma vez que necessitam destas para sobreviverem em um mercado competitivo. Assim, procuram meios para obter e controlar o acesso às informações. Um destes meios é o sistema de informação.

Além disso, para manter a sustentabilidade do empreendimento rural são necessários vários fatores, entre eles pode-se citar:

a) Controle das operações internas para evitar retrabalhos e desperdício.

b) Controle energético rígido para manter o equilíbrio das entradas e saídas.

c) Controle dos prazos.

Uma maneira de alcançar estes fatores de forma eficiente é construir um sistema de gestão integrada que contemple as necessidades do produtor rural e que permita realizar a análise de todo o seu agronegócio. Nesse contexto, um instrumento para medir a sustentabilidade do empreendimento rural é o balanço energético.

A finalidade do balanço energético é mensurar a eficiência energética, substituindo as fontes de energia não renováveis por outras renováveis, avaliando sistemas produtivos para alcançar sistemas que requeiram menores entradas de energia e gerem uma maior saída energética $^{1^{*}}$.

Sendo assim, o objetivo deste trabalho é desenvolver um modelo de sistema de informação para o controle energético em uma pequena propriedade rural (com até 30 hectares), com características como facilidade de uso, baixo custo e capaz de fornecer informações que tragam vantagens competitivas para o produtor, onde o sistema poderá

\footnotetext{
${ }^{*}$ BUENO, O. C. Notas de aula da disciplina análise energético-econômica de sistemas agroindustriais. Botucatu: Unesp, 2006. Não publicado
} 
retransmitir os valores do balanço energético da propriedade rural para uma base centralizada (através da internet), criando um banco de dados nacional, com informações a respeito das culturas, valor energético, consumo de energia e a eficiência na produção e distribuição da energia.

O uso de um sistema de informação no meio rural propiciará ao produtor levantar várias informações para o processo decisório. Segundo Laudon (Laudon, 2004), alguns dos benefícios são:

- Disponibilidade de informação certa, na hora certa e nos pontos certos;

- Compartilhamento de base de dados única e não redundantes;

- Eliminação do esforço gerencial e operacional nas interfaces entre sistemas que não conversam entre si;

- Aperfeiçoamento do processo de planejamento operacional, o qual passa a ser mais transparente, estruturado e com responsabilidades mais definidas;

- Melhoria do desempenho operacional, conseguindo vantagens competitivas em relação à concorrência.

- Melhoria da informação para a tomada de decisão;

- Automatização das tarefas rotineiras;

- Melhoria do controle interno das operações;

- Aumento da capacidade de reconhecimento dos problemas com maior antecedência;

- Aumento da produtividade e da competitividade. 
Tendo em vista a globalização do mercado e a competitividade gerada, é necessário o estudo e a criação de ferramentas que ajudem o produtor a controlar o seu negócio e obter uma vantagem competitiva sobre a concorrência.

\subsection{Organização do trabalho}

No capítulo 2 será apresentada uma revisão bibliográfica sobre os assuntos abordados neste trabalho. O capítulo 3 é dedicado aos métodos, modelos e convenções adotados na elaboração do trabalho. O capítulo 4 apresenta os resultados do trabalho. No capítulo 5 serão realizadas as discussões sobre o trabalho e no capítulo 6 é apresentada a conclusão e as considerações finais. 


\section{Revisão da Literatura}

\subsection{Energia}

\subsubsection{Conceito}

Energia é a capacidade de um objeto em realizar trabalho ou executar uma ação. Ela está presente no dia a dia sobre diversas formas, e utiliza-se mesmo sem perceber: energia luminosa que chega aos olhos, energia sonora que adentra aos ouvidos, energia térmica sentida na ponta dos dedos quando se toca um objeto quente, etc.

Existem ainda outras formas de energia, muitas delas não sentidas ou percebidas tão facilmente no dia a dia, como a energia eletromagnética. Muitas vezes, uma forma de energia é transformada em outra. Todo objeto capaz de realizar alguma forma de trabalho possui certa quantidade de energia armazenada (Energia, 2010).

Existem duas grandes categorias para classificar as diversas formas de energia: A energia do movimento (ou energia cinética) e a energia que depende da posição ou configuração (energia potencial).

A capacidade da energia em realizar um determinado trabalho é medida em Joule (J). Um Joule é a energia necessária para mover um Newton (N) por 1 metro (m). De acordo com Instituto Nacional de Metrologia (INMETRO, 2003), o joule é a unidade a ser adotada em todos os sistemas para indicar as grandezas de trabalho, energia e quantidade de calor.

Basicamente, a energia pode estar disponível em duas formas básicas: A Energia Potência e a Energia Cinética. 


\subsubsection{Energia potencial}

Segundo a Brasil Escola (BRASIL ESCOLA, 2009a), energia potencial é a energia armazenada por um objeto para realizar trabalho em função da posição que ele ocupa. Imagine uma barragem (hidrelétrica) (Figura 1). Se a água dos dois lados estiver no mesmo nível, o rotor estará parado. Agora se o nível da água for elevado em um dos lados, terá uma energia potencial armazenada. Se as válvulas se abrirem, as turbinas irão girar. Desta forma, a energia potencial é transformada em energia cinética (movimento da água) e, posteriormente, em energia elétrica (através da movimentação dos rotores).

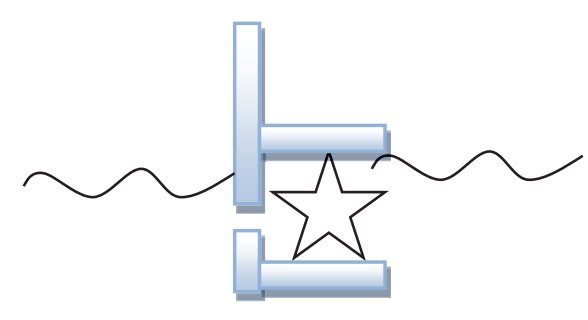

Mesmo nível: Rotor parado

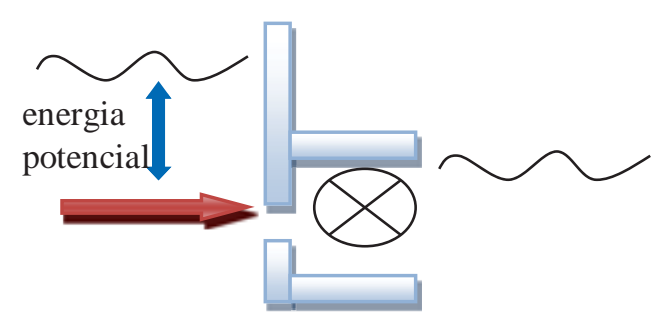

Nível diferente: Rotor gira

Figura 1: Funcionamento de uma usina Hidrelétrica

Existem vários tipos de energia potencial: A energia potencial gravitacional, a energia potencial elástica, energia potencial elétrica, energia potencial química, energia potencial nuclear, etc. A principais são a gravitacional e a elástica.

A energia potencial gravitacional existe devido à força da gravidade. Sendo assim, se um objeto possui uma massa e esta é elevada a certa altura, este objeto passa a ter uma energia potencial armazenada. A equação será:

$$
E_{p}=M \times G \times H
$$

onde: 
$\mathrm{E}_{\mathrm{p}}=$ Energia potencial $(\mathrm{N})$

$\mathrm{M}=$ Massa do objeto $(\mathrm{Kg})$

$\mathrm{G}=$ Força gravitacional exercida sobre o objeto $\left(\mathrm{N} \cdot \mathrm{m}^{2} / \mathrm{kg}^{2}\right)$

$\mathrm{H}=$ Altura do objeto(m)

A segunda forma de Energia Potencial é a elástica. Imagine um bloco de massa M preso a uma mola (Figura 2).

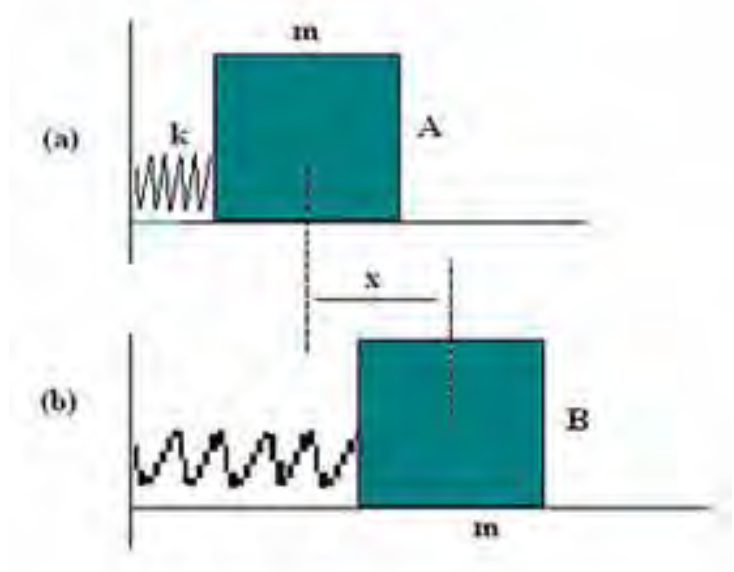

Figura 2: Energia potencial elástica.

Fonte: Brasil Escola, 2009a.

Se o bloco for deslocado (de um ponto A para um ponto B), será armazenada certa quantidade de energia dada pela formula 2:

$$
E_{p e l}=\frac{k \times x^{2}}{2}
$$

onde:

$\mathrm{E}_{\mathrm{pel}}=$ Energia Potencial Elástica $(\mathrm{J})$

$\mathrm{k}$ = constante elástica da mola (deformação da mola)

$\mathrm{x}=$ Distância percorrida entra a mola em repouso e o novo local do objeto (m). 


\subsubsection{Energia cinética}

Segundo a Educar (EDUCAR, 2010), energia cinética é a energia gerada pela movimentação de um objeto. Assim, todo objeto em movimento possui energia cinética. Como esta energia provém do movimento, ela depende da massa do objeto e de sua velocidade. Um exemplo disso é energia em um carro em movimento. Se o mesmo colidir com um objeto, a energia cinética do carro será transferida para o objeto, provocando o deslocamento do mesmo.

Quando temos um objeto (por exemplo, um carro) e sobre este atuam diversas forças e a força resultante não é nula, este imprime aceleração, fazendo com que haja variação da velocidade do corpo. Quanto maior a velocidade do carro, maior a energia cinética.

A energia cinética é dada pela fórmula 3:

$$
E_{c}=\frac{M \times V^{2}}{2}
$$

onde:

$$
\begin{aligned}
& E_{c}=\text { Energia Cinética }(J) \\
& M=\text { Massa do objeto }(\mathrm{Kg}) \\
& V=\text { Velocidade do objeto }(\mathrm{m} / \mathrm{s})
\end{aligned}
$$

\subsubsection{Formas de produção de energia.}

Muitas são as formas de produção de energia. Muitas delas utilizam mais de um tipo de energia para realizar a transformação em energia disponível. Um exemplo disso é o uso da energia potencial usada para produzir energia elétrica. A seguir, têm-se algumas dessas formas: 


\subsubsection{Energia Hidrelétrica}

Energia gerada através do movimento das águas, usando a energia potencial acumulada nos reservatórios e aproveitando o desnível natural ou artificial dos rios. Esta água movimenta turbinas (energia cinética), que por sua vez estão ligadas a geradores, produzindo energia elétrica (Figura 3).

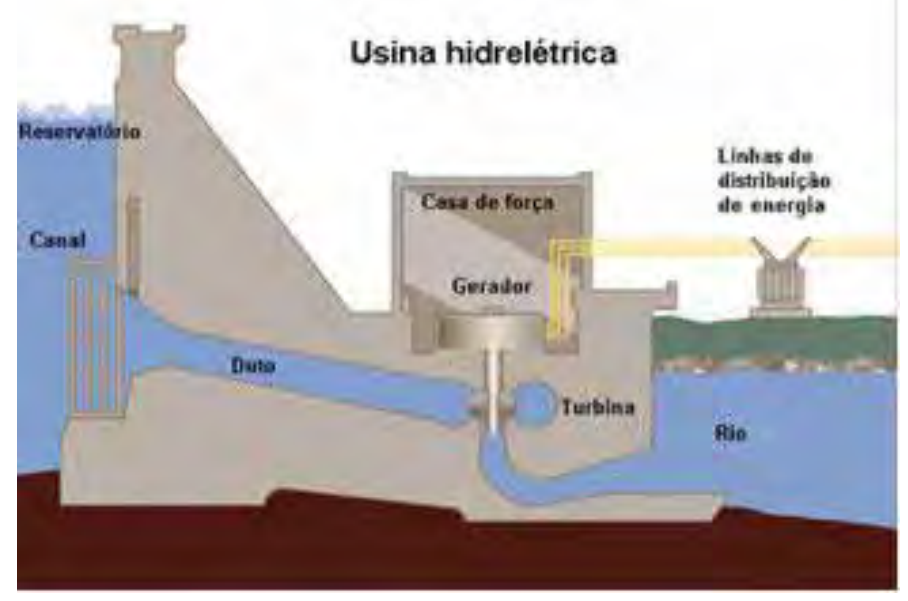

Figura 3: Esquema de funcionamento de uma hidrelétrica.

Fonte: Brasil Escola, $2009 b$

Segundo a Brasil Escola (BRASIL ESCOLA, 2009b), a eficiência energética das hidrelétricas é muito grande, girando na casa dos 95\%. Apesar do alto custo inicial e do custo de manutenção (alto), o custo com o combustível (água) é nulo.

É a segunda maior fonte de eletricidade do mundo (18\% de toda energia produzida no mundo) e no Brasil, é a principal fonte de energia (95\% de nossa energia elétrica é oriundo das hidrelétricas). É considerada uma fonte limpa, apesar das inundações e os impactos ecológicos provocados durante a fase de construção da usina e é uma fonte de energia renovável (BRASIL ESCOLA, 2009b). 


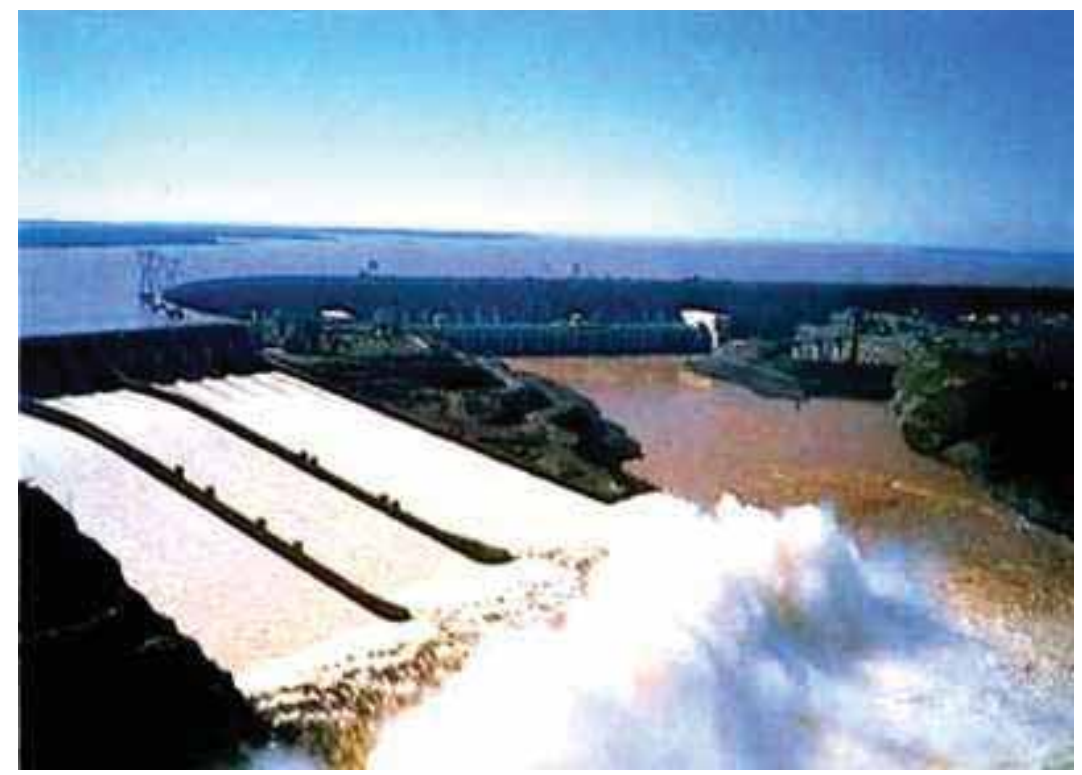

Figura 4: Usina hidrelétrica de Itaipu, na fronteira do Brasil com o Paraguai.

Um grande problema desse tipo de energia é a transmissão da energia, visto que a maioria das usinas estão afastadas dos centros consumidores, sendo necessário a construção de uma rede de transmissão.

\subsubsection{Energia mecânica}

É a energia que pode ser transferida por meio de força e produz movimento. Ela é a soma da energia potencial e cinética (BRASIL ESCOLA, 2009b). Em exemplo é o eixo de um motor, que girando, transmite energia pelo movimento. Ela é dada pela fórmula (4):

$$
E_{m}=E_{p}+E_{c}
$$

onde:

$\mathrm{E}_{\mathrm{m}}=$ energia mecânica

$\mathrm{E}_{\mathrm{c}}=$ energia cinética

$\mathrm{E}_{\mathrm{p}}=$ energia potencial. 


\subsubsection{Energia Térmica}

É conhecida também como energia calorífica (calor). Todo corpo é composto por partículas que estão em constante movimento, vibração ou rotação, tendo uma energia cinética associada. Assim, quando estas partículas se movimentam, ela libera energia em forma de calor, podendo ser utilizada para aquecer objetos. Normalmente, esta energia é produzida pela queima de algum tipo de combustível (carvão, petróleo, gás natural, biomassa (da cana), etc) (Energia Termica, 2010). Este tipo de energia pode ser utilizada em um processo de transformação para gerar energia elétrica (Figura 5). Neste caso, o vapor gerado na caldeira é utilizado para movimentar a turbina (que está ligada a um gerador), produzindo energia elétrica.

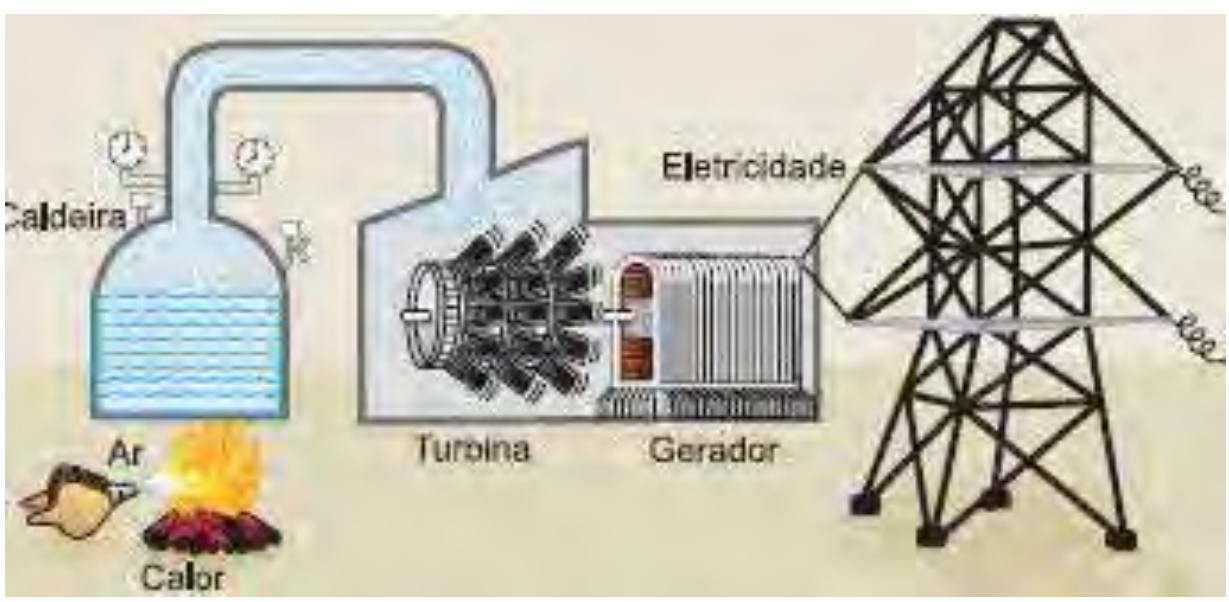

Figura 5: Transformação da energia térmica em elétrica.

Fonte: Energia Termica, 2010

\subsubsection{Energia Geotérmica}

É a energia gerada a partir do calor nas profundas camadas da crosta terrestre (GEOTÉRMICA, 2010). Em algumas regiões, esta temperatura pode superar os $5.000^{\circ} \mathrm{C}$. Normalmente é utilizada combinando com a água para acionar turbinas elétricas e gerar energia (Figura 6). Quase 3.000.000 de joules são gerados por segundo utilizando este tipo de 
energia. Ainda é muito pouco utilizada e os principais países que aproveitam esta forma de energia são os EUA, Portugal (Açores), México, Japão, Quênia, Filipinas e a Islândia.

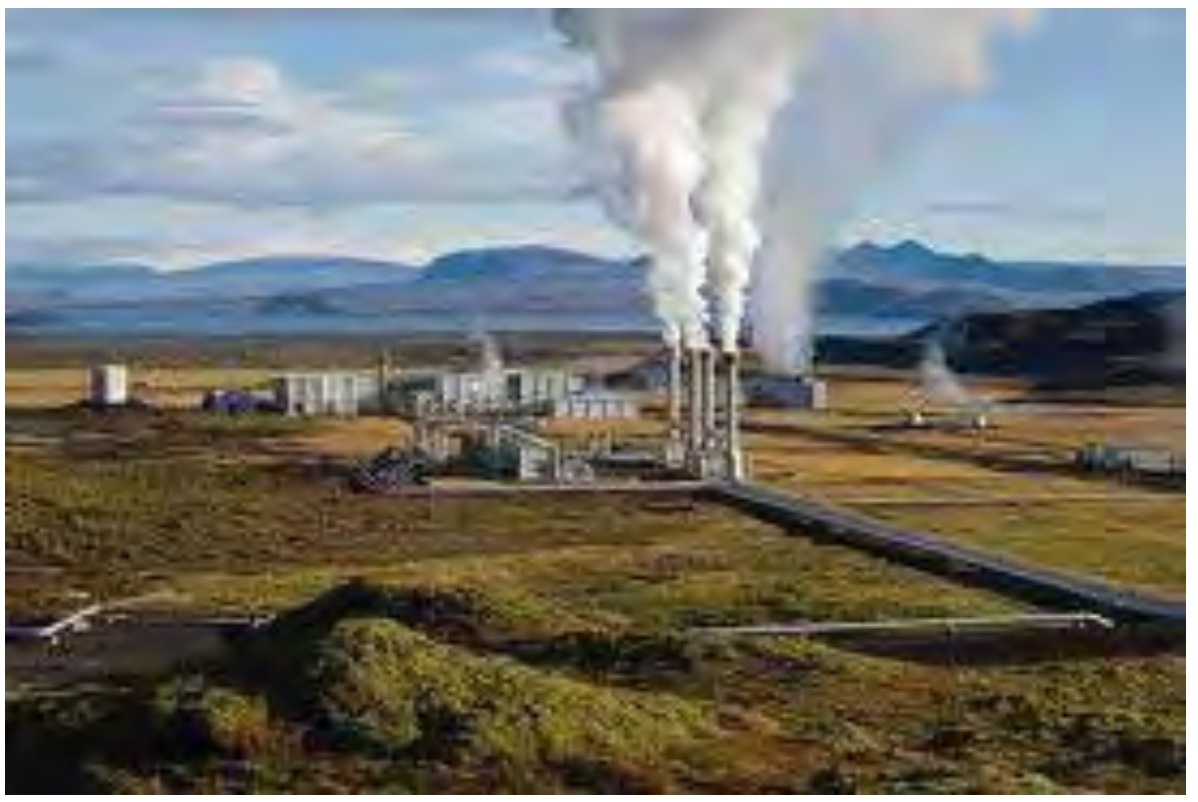

Figura 6: Usina geotérmica na Islândia.

Fonte: GEOTÉRMICA,2010

Em alguns locais, como por exemplo, em Larderello, na Itália, é possível encontrar fontes de vapor seco, isto é, locais onde a pressão dos gases expelidos do magma é forte o suficiente para movimentar turbinas (GEOTÉRMICA, 2010).

Segundo Brown (BROWN, 1999), a desvantagem da utilização desta fonte de energia é que junto com o vapor chegam gases dissolvidos (normalmente ácido sulfídrico), prejudicial à saúde, com propriedades corrosivas e com odor desagradável.

\subsubsection{Energia fóssil}

É formada a partir do acúmulo de materiais orgânicos no subsolo ao longo de milhões de anos (ABC DA ENERGIA, 2010). É composta de carbono e suas principais formas são o carvão mineral, o petróleo e o gás natural. 
É a principal fonte de energia utilizada nos meios de transporte. A geração de energia a partir desta fonte é poluente, gerando grandes quantidades de poluentes e acentuando o efeito estufa com a liberação de $\mathrm{CO}_{2}$. Também é uma fonte não renovável. Em algumas localidades, é utilizada para queimar e aquecer a água, gerando energia através do vapor.

\subsubsection{Energia Solar}

É a energia produzida pela radiação solar (SOLAR, 2010). É utilizada para gerar calor ou eletricidade (energia fotovoltaica). A energia fotovoltaica é pouco explorada no Brasil e a maior utilização da energia solar é o aquecimento da água, principalmente em residência.

A energia fotovoltaica é fornecida de painéis contendo células fotovoltaicas ou solares que sob a incidência do sol geram energia elétrica. A energia gerada pelos painéis é armazenada em bancos de bateria, para posterior utilização. A energia é gerada quando os fótons do sol atingem as placas de silício e provocam a geração de energia.

\subsubsection{Energia de Biomassa}

É a energia gerada a partir da decomposição de materiais orgânicos (produzindo gás metano para a produção de energia), ou da queima do bagaço da cana, aquecendo água e produzindo energia. É uma forma de energia renovável.

\subsubsection{Energia eólica}

É a energia gerada a partir do vento. Grandes hélices são instaladas em áreas abertas e através da movimentação das pás (Figura 7), é produzida a energia (EÓLICA, 2010). 
É uma fonte de energia renovável e não poluente, mas ainda é pouco utilizada. Seus maiores impactos ambientais são a colisão dos pássaros com as pás das hélices e o ruído gerado pelos aero geradores.

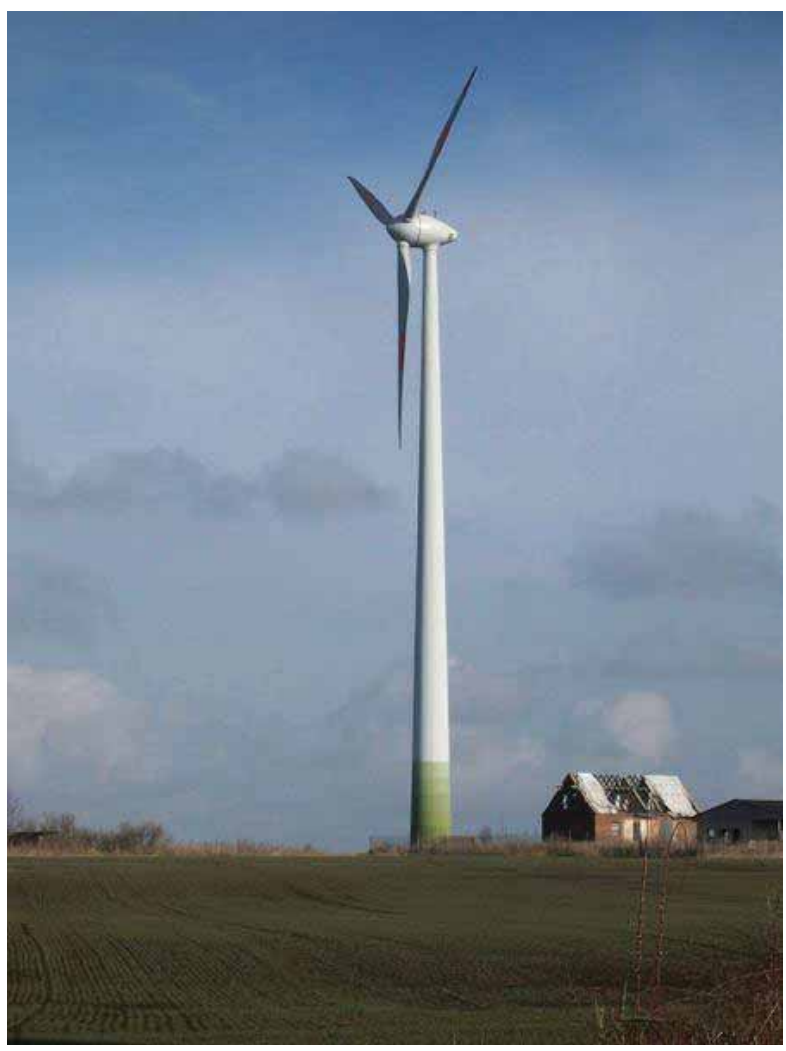

Figura 7: Aerogerador Enercon E-66 - Alemanha

O Brasil produz e exporta equipamentos para usinas eólicas, mas elas ainda são pouco usadas. Os principais representantes são as Usinas do Camelinho (1 mW, em MG), Mucuripe (1,2mW) , Prainha (10mW) no Ceará, e Fernando de Noronha em Pernambuco (EÓLICA, 2010). 


\subsubsection{Energia Nuclear}

É a energia gerada através de elementos químicos ricos em energia. É proveniente da desintegração do núcleo, que libera muita energia (Energia, 2010). Esta energia é aproveitada para esquentar a água e gerar energia pelo uso do vapor (Figura 8). Não produz muitos poluentes, mas existe o problema do lixo nuclear. É uma energia muito importante para vários países europeus e os EUA, representando, em muitos casos, a principal fonte de energia em alguns países.

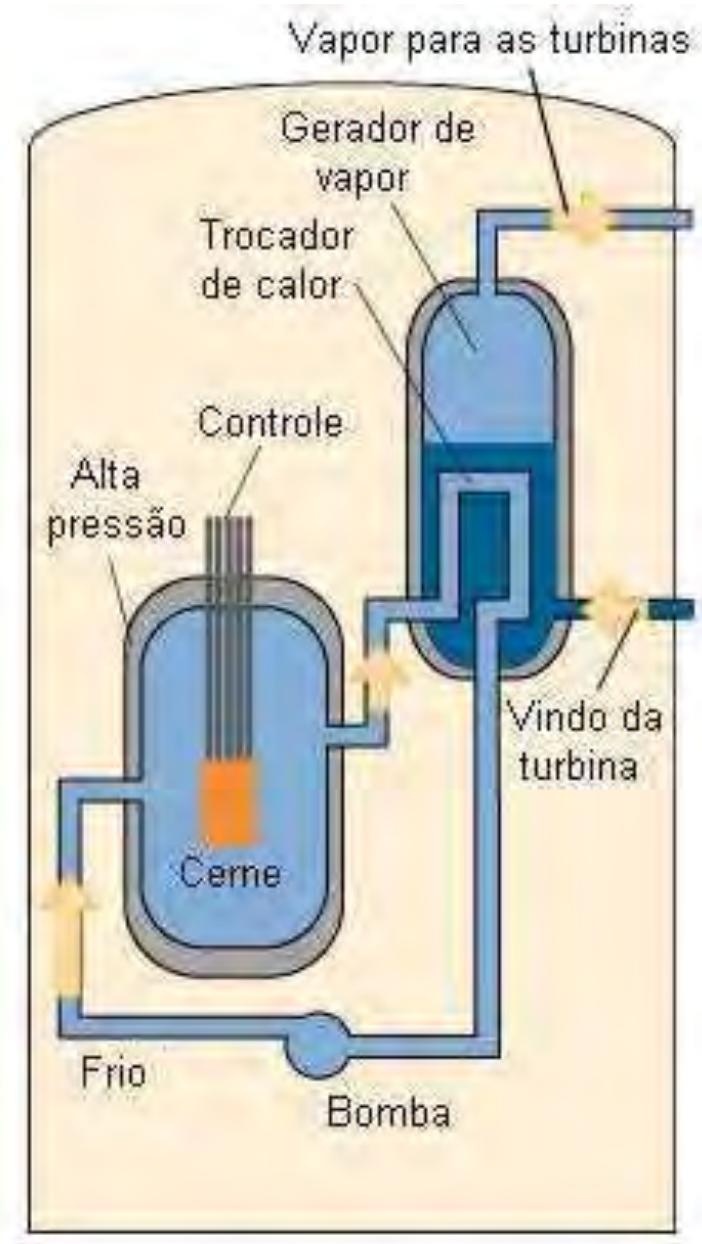

Figura 8: Diagrama do reator de uma Usina Nuclear (Energia, 2010)

Na Figura 8, é apresentado o esquema básico de um reator nuclear. A água é mantida sobre pressão em um reservatório com um núcleo atômico, que aquece a água. Esta água 
aquecida (mas radiativa) é enviada para um trocador de calor, que aquece a água (não contaminada), gerando vapor. Este vapor é utilizado para movimentar as turbinas e gerar energia. Após a utilização do vapor pela turbina, o mesmo é resfriado e retorna em forma de água para o trocador de calor, iniciando um novo ciclo. O mesmo acontece com a água contaminada, que através de uma bomba, retorna para o reservatório.

\subsubsection{Energia gravitacional}

É a energia gerada a partir do movimento das águas oceânicas das marés (Energia, 2010). Constrói-se uma barragem, formando-se um reservatório junto ao mar. Quando a maré é alta, a água enche o reservatório, passando através da turbina e produzindo energia elétrica, e na maré baixa o reservatório é esvaziado e água que sai do reservatório, passa novamente através da turbina, em sentido contrário, produzindo energia elétrica (Figura 9). Este tipo de fonte é também usado no Japão e Inglaterra.

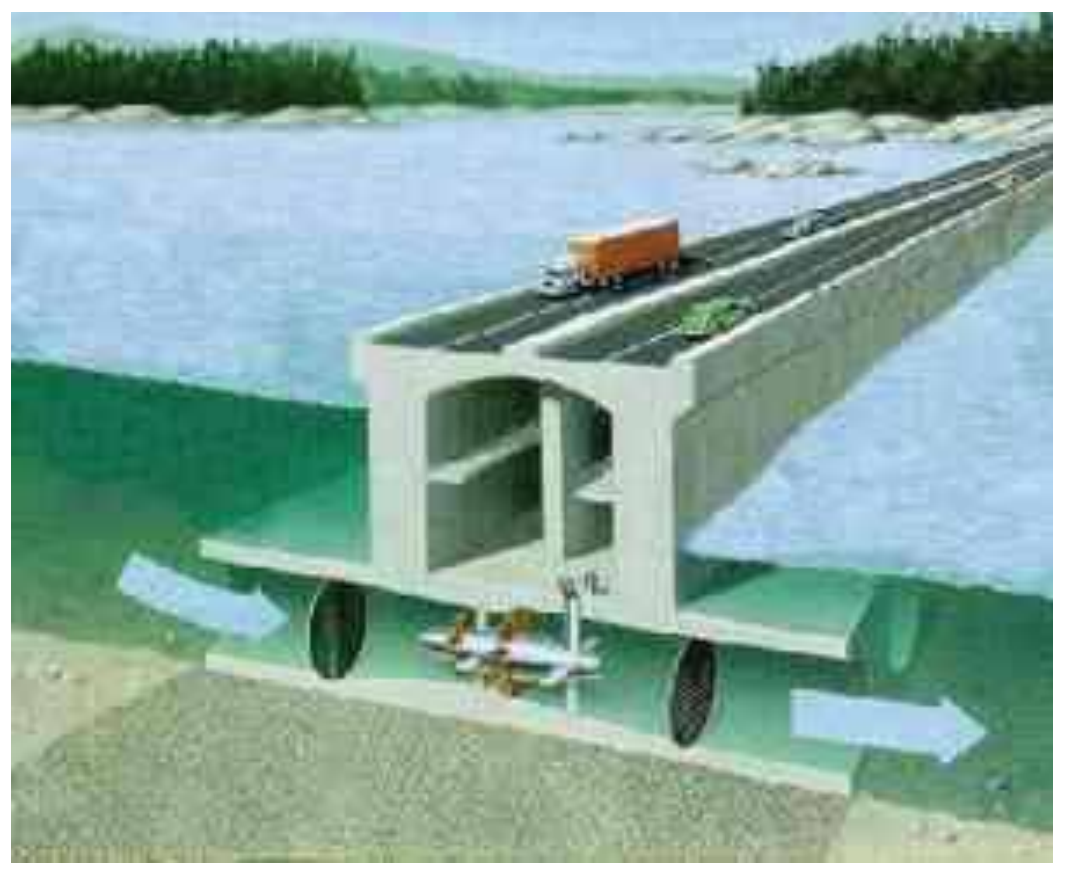

Figura 9: Caixa de concreto por onde, no sobe e desce das marés, passa a água do mar cuja energia é aproveitada na geração de eletricidade (Energia,2010). 


\subsubsection{Energia química}

É a energia gerada a partir da reação química de alguns elementos (Energia, 2010). Normalmente, é liberada energia na forma de calor. Uma forma muito comum é a respiração e a fotossíntese.

É também a energia potencial química encontrada nos alimento. Normalmente, parte da energia é utilizada e outra parte é transformada em calor.

\subsection{Balanço Energético}

Segundo a Agência de Serviços Públicos de Energia do Estado do Espírito Santo (ASPE, 2010), o "Balanço Energético (BE) é um conjunto de quadros que procuram explicitar os fluxos e as quantidades de energia que percorrem o sistema econômico e social de uma determinada região, estado ou país. Ele permite visualizar a forma como se produz, importa, exporta, transforma e utiliza a energia".

Normalmente é formado por um conjunto de tabelas que cruzam dados energéticos com diferentes setores econômicos e sociais. Estes dados são utilizados para conhecer o consumo de energia de um setor ou população e é um instrumento para realizar o planejamento energético por parte dos responsáveis pela oferta de energia.

O Balanço Energético visa estabelecer os fluxos de energia, identificando sua demanda total e eficiência, refletida pelo ganho líquido de energia e pela relação saída/entrada, além da quantidade necessária para produzir ou processar um quilograma de determinado produto. Nesse processo, quantificam-se todos os insumos utilizados e produzidos que são transformados em unidades de energia. A determinação da eficiência energética é importante 
instrumento no monitoramento da sustentabilidade da agricultura ante o uso de fontes de energia não-renováveis (HETZ (1994) apud SIQUEIRA et al., 1999; BUENO et al., 2000).

\subsubsection{O BE no Mundo}

Foi criado pelos países industrializados em 1950 para monitorar e organizar as estatísticas energéticas, devido ao crescimento do consumo de energia em todo o mundo, como forma de planejar a expansão da oferta de energia. A partir da primeira crise do petróleo (1974), a importância do BE aumentou em todo o mundo, pois a matriz de energia foi diversificada e sua importância cresceu, não somente nos países desenvolvidas, mas também nos países em desenvolvimento, que necessitavam conhecer a composição energética de seus países.

\subsubsection{O BE no Brasil}

O Balanço Energético Nacional (BEN) nasceu em 1976, fruto dos esforços do Ministério das Minas e Energia (MME) para consolidar os dados sobre o setor energético no país.

Em 1978, a portaria $n^{0} 1221$, de 11/08/78, do MME, criou o Comitê Organizador do BEN (COBEN) como órgão de assessoria da Secretaria Geral do MME.

O BEN (BEN, 2010) busca ser um retrato cada vez mais completo da interação entre o setor energético e a sociedade, trazendo dados como consumo energético por setor e região, recursos e reservas energéticas, e outras informações complementares. O BEN vinha sendo executado pelo Departamento Nacional de Desenvolvimento Energético, mas, agora está sendo feito pela Empresa de Pesquisa Energética - EPE. 
A EPE é uma empresa pública, instituída nos termos da Lei n 10.847, de 15 de março de 2004, e do Decreto n 5.184, de 16 de agosto de 2004. Sua finalidade é prestar serviços na área de estudos e pesquisas destinados a subsidiar o planejamento do setor energético, tais como energia elétrica, petróleo e gás natural e seus derivados, carvão mineral, fontes energéticas renováveis e eficiência energética, dentre outras.

Os dados utilizados pelo BEN advêm das instalações consumidoras (indústria e serviços), unidades sucroalcooleiras, concessionárias de energia elétrica e gás natural e refinarias de petróleo e centrais petroquímicas.

\subsubsection{Fluxo Energético}

É o estudo do fluxo de energia que envolve as diversas formas energéticas, desde a sua produção até a etapa final. Inclui todas as entradas e saídas de energia (em suas mais variadas formas), calculando o consumo em cada fase. Segundo a primeira lei da termodinâmica, a energia não é criada nem destruída, mas sim transformada de uma forma para outra. Assim, a energia de uma fonte é transformada em outra. O fluxo de energia é dado, então, pela razão do trabalho num período de tempo. Sendo assim, o comparativo da capacidade humana com a do animal, ou com as máquinas, nos dá a ideia de quanto de energia é necessário investir num sistema de produção agrícola ou florestal conforme a tecnologia empregada.

Somente para fins de comparação (OLIVEIRA JR, 2005), em uma hora de trabalho um trator pode gerar 35,2kW de trabalho, consumindo 15,2 litros de gasolina, enquanto que um cavalo conseguiria realizar $0,746 \mathrm{KW}$ de trabalho. Se esta comparação fosse estendida para o ser humano, este seria capaz de realizar aproximadamente $0,0746 \mathrm{KW}$ de trabalho no mesmo período. Isso quer dizer que um trator realiza o trabalho de aproximadamente 471 pessoas no mesmo período de tempo. Tomando por base estes dados, fica evidente a superioridade de um processo mecanizado na obtenção de resultados rápidos e a baixo custo. 
O custo relativo do trabalho humano e do combustível fóssil afeta o custo do produto. Essa comparação é importante e podem ser feitas entre dois ou mais sistemas de produção, conforme o grau de mecanização pretendido, potencializando as entradas de energia com investimentos em máquinas, adubação, irrigação, manejo e processamento. Uma boa aplicação dos recursos energéticos pode garantir o sucesso de um sistema produtivo.

Segundo Campos (CAMPOS et al., 1998), pode-se classificar as possíveis entradas de energia em dois fluxos: externo e interno.

O fluxo externo (correspondente às energias injetada no sistema) divide-se em:

- Energia direta: energia fóssil (combustíveis, lubrificantes, adubos, corretivos, pesticidas, pneus), energia elétrica e energia biológica (trabalho humano ou animal, sementes, mudas e biomassa).

- Energia indireta: energia encontrada em bens industriais, como tratores e equipamento agrícolas, calculada através da depreciação energética.

O fluxo interno (Correspondente à energia convertida dentro do sistema) divide-se em:

- Primário: energia contida nas fibras e resíduos da produção.

- Secundário: energia de transformação dentro do processo de produção.

Ainda, segundo Campos (CAMPOS et al., 1998), fontes de energia primária são as fontes de energia encontradas diretamente na natureza ou de subprodutos de resíduos industriais e naturais. Alguns exemplos são o petróleo, o gás natural, o carvão, a lenha, o bagaço da cana, palha de arroz, cavacos de madeiras, etc., enquanto que as fontes de energia secundárias são as fontes resultantes de um ou mais processos de transformação da energia das fontes primárias: óleo diesel, gasolina, querosene, eletricidade, álcool, etc. 


\subsubsection{Classificação segundo as fontes de energia}

A classificação das fontes de energia podem ser Biológicas, Fósseis e Industriais. Segundo Comitre (COMITRE, 1993), a energia direta é subdividida em Biológica (energia animal, resíduos de plantas e animais, sementes, plantas, etc...) e Fóssil (que tem suas origens no petróleo, como os adubos químicos, diesel, gasolina e todos os derivados do petróleo). A energia indireta é considerada a energia proveniente de um processo industrial, como os tratores e implementos agrícolas. Assim, a energia industrial é ponderada nos cálculos a partir da depreciação dos equipamentos durante a vida útil dos mesmos (CASTANHO FILHO E CHABARIBERY, 1983).

Para efeitos de cálculo da energia industrial utilizada no sistema produtivo, a quantidade de energia será dada pela depreciação energética do objeto.

\subsubsection{Perdas}

Podem ocorrer perdas de energia, como por exemplo, a perda de energia elétrica durante a transmissão através do calor, fazendo que nem toda a energia seja aproveitada* .

\subsubsection{Consumo final}

É a energia utilizada para a produção de bens ou serviços. Normalmente são classificados em Residencial, Comercial, Energético, Agropecuário, Transportes, Industrial e outros*.

\footnotetext{
${ }^{*}$ BUENO, O. C. Notas de aula da disciplina análise energético-econômica de sistemas agroindustriais. Botucatu: Unesp, 2006. Não publicado
} 


\subsubsection{Poder Calorífico}

É a quantidade de energia liberada através da queima de um determinado objeto ${ }^{*}$ Um exemplo comparativo pode ser visto na Tabela 1 :

Tabela 1: Poder calorífico por Massa específica

\begin{tabular}{|c|c|c|}
\hline Fontes energéticas & Massa Específica kg/m³ (1) & Poder Calorífico kcal/kg \\
\hline Petróleo médio PCS & 864 & 10800 \\
\hline Petróleo médio PCI & 864 & 10200 \\
\hline Gás Natural Seco ${ }^{2}$ & - & 9317 \\
\hline Carvão Vapor (Mix) kcal/kg & - & 5346 \\
\hline Carvão Metalúrgico Nacional & - & 6800 \\
\hline Carvão Metalúrgico Importado & - & 7900 \\
\hline Energia Hidráulica $^{3}$ & - & 3132 \\
\hline Lenha & 300 & 3300 \\
\hline Bagaço de Cana $^{4}$ & - & 2257 \\
\hline Lixívia & - & 3030 \\
\hline Óleo Diesel & 852 & 10750 \\
\hline Óleo Combustível Médio & 1013 & 10900 \\
\hline Álcool Etílico Hidratado & 809 & 6650 \\
\hline Alcatrão & - & 9000 \\
\hline
\end{tabular}

(1) A temperatura de $20^{\circ} \mathrm{C}$, para os derivados de petróleo e de gás natural.

(2) $\mathrm{kcal} / \mathrm{m}^{3}$

(3) $\mathrm{kcal} / \mathrm{kWh}$

(4) Bagaço com $50 \%$ de umidade

(fonte: ASPE,2010)

\subsubsection{Unidades}

Segundo o Balanço Energético do Estado de São Paulo - BEESP (BEESP, 2003), por razões históricas, cada unidade do Sistema Internacional (SI) está associada a alguma forma de energia. Assim, à caloria - cal se associa o calor (proveniente do petróleo, do carvão, da lenha), ao joule - J se associa a energia mecânica (de origem hidráulica, eólica etc.) ao Watt hora - Wh se associa a eletricidade, de forma que qualquer que seja a unidade escolhida para se contabilizar um balanço de energia, surge imediatamente o problema de conversibilidade entre as diversas formas de energia. No Sistema Internacional (SI), o joule é adotado em todos os sistemas para indicar magnitudes de trabalho, energia e calor. 
Para evitar problemas de conversão de valores, foi adotada a "tonelada equivalente de petróleo - TEP", que é a quantidade de energia encontrada em uma tonelada de petróleo e é a unidade básica adotada na composição do Balanço Energético Nacional - BEN. O TEP é baseado no petróleo, devido a sua importância como fonte de energia e é medida através da queima de um objeto em um calorímetro e este é comparado com o poder calorífico (medido em kcal/kg) de um petróleo médio.

No Brasil, 1kWh de eletricidade corresponderia à quantidade de calor necessária para produzi-la $(13,1 \mathrm{GJ})$ e não ao seu equivalente calórico (3,6GJ). O Brasil adota o valor de 300g de óleo combustível para cada kWh gerado.

\subsubsection{Consumo energético do setor agropecuário}

Segundo o BEN (BEN, 2009), o consumo de energia no setor agropecuário (Figura 10) teve uma redução até o ano 2000 devido a aplicação de técnicas mais eficientes de manuseio da terra e a menor utilização da lenha como fonte de energia. Mas a partir de 2000, ocorreu um aumento significativo, gerado principalmente pelo processo de mecanização da agricultura (com o consumo de óleo diesel) (Figura 11).

\section{Agropeaário}

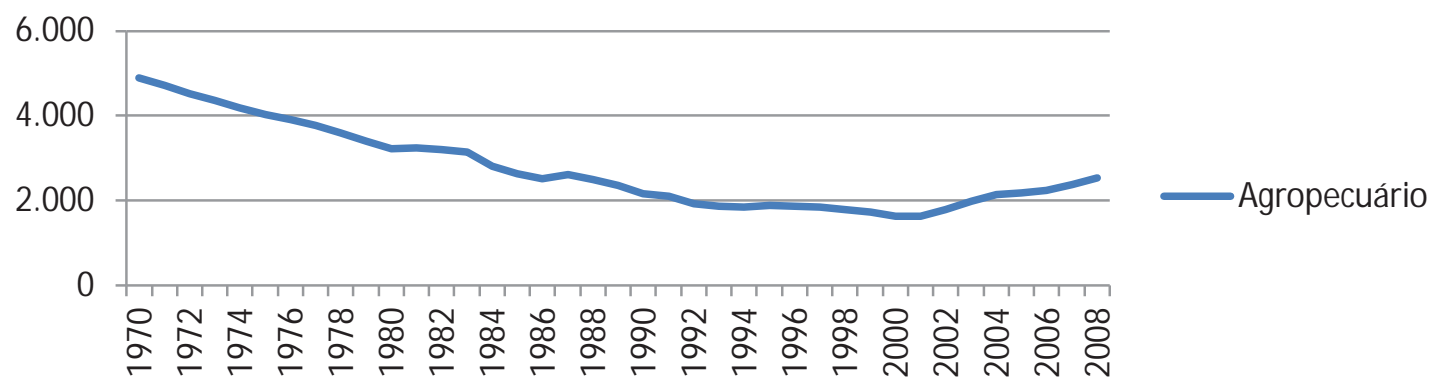

Figura 10: Consumo energético da agricultura em 103 TEP

Fonte: BEN, 2009 


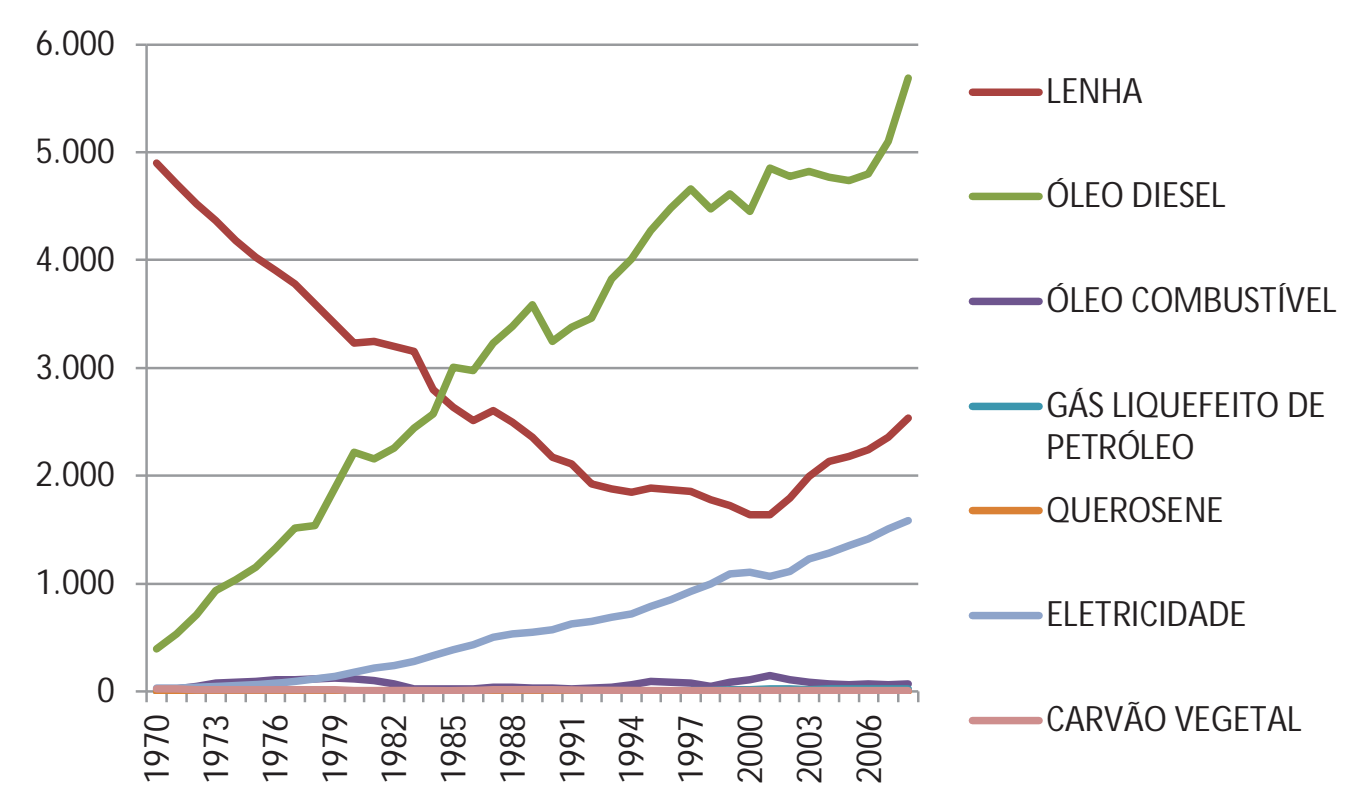

Figura 11: Composição do consumo energético na agricultura

Fonte: BEN, 2009

Como se pode observar, junto com o aumento da produção agrícola, ocorreu um efeito colateral que é o consumo de óleo diesel (para os maquinários). Torna-se necessário criar instrumentos para avaliar este consumo e mensurar a real necessidade de recursos não renováveis (como o óleo diesel) e sua possível substituição pelo biodiesel, melhorando a eficiência dos meios produtivos, reduzir a dependência de energia não renováveis e manter a sustentabilidade do negócio (BEN, 2009).

\subsubsection{Matriz energética e o Brasil do futuro}

Segundo o levantamento feito pela Agência Nacional de Minas e Energia, intitulado "Levantamento da Matriz energética Nacional em 2030" (BEN 2030, 2010), o crescimento no consumo de energia terá um aumento na ordem de 23\% até 2030. 
Nesse cenário, o consumo energético da agricultura teria um aumento de 8.358 milhões de TEP (em 2005) para 28.602 milhões de TEP em 2030, equivalendo a quase 70\% do consumo de toda a energia residencial, tendo um dos maiores crescimentos entre todos os setores (5\% ao ano, superado apenas pelo setor comercial (5,5\%)). Em dados divulgados pelo IBGE, o Produto Interno Bruto (PIB) da agricultura deve crescer de 66,89 bilhões (2005) para 187,27 bilhões em 2030. Isso representa um aumento de quase 180\%, superando até o crescimento da indústria (crescimento previsto de 145\% entre 2005 a 2030). Assim, esse é um setor que merece muita atenção, pois representará quase 9\% do PIB Brasileiro.

A Tabela 2 mostra os valores esperados de crescimento do PIB por setor:

Tabela 2: Produto Interno Bruto por Setor (em US\$ bilhões de 2005).

\begin{tabular}{|lr|r|r|r|}
\cline { 2 - 5 } \multicolumn{1}{c|}{} & $\mathbf{2 0 0 5}$ & $\mathbf{2 0 1 0}$ & $\mathbf{2 0 2 0}$ & $\mathbf{2 0 3 0}$ \\
\hline Agricultura & 66,89 & 84,86 & 121,61 & 187,27 \\
\hline Industria & 318,52 & 384,39 & 529,78 & 782,88 \\
\hline Serviços & 410,89 & 486,59 & 726,05 & 1163,13 \\
\hline Total & $\mathbf{7 9 6 , 3}$ & $\mathbf{9 5 5 , 8 4}$ & $\mathbf{1 3 7 7 , \mathbf { 4 4 }}$ & $\mathbf{2 1 3 3 , 2 8}$ \\
\hline
\end{tabular}

Fonte: BEN 2030

Assim, o setor da agricultura está em expansão e representa uma grande fonte de divisas para o Brasil (Figura 12). 


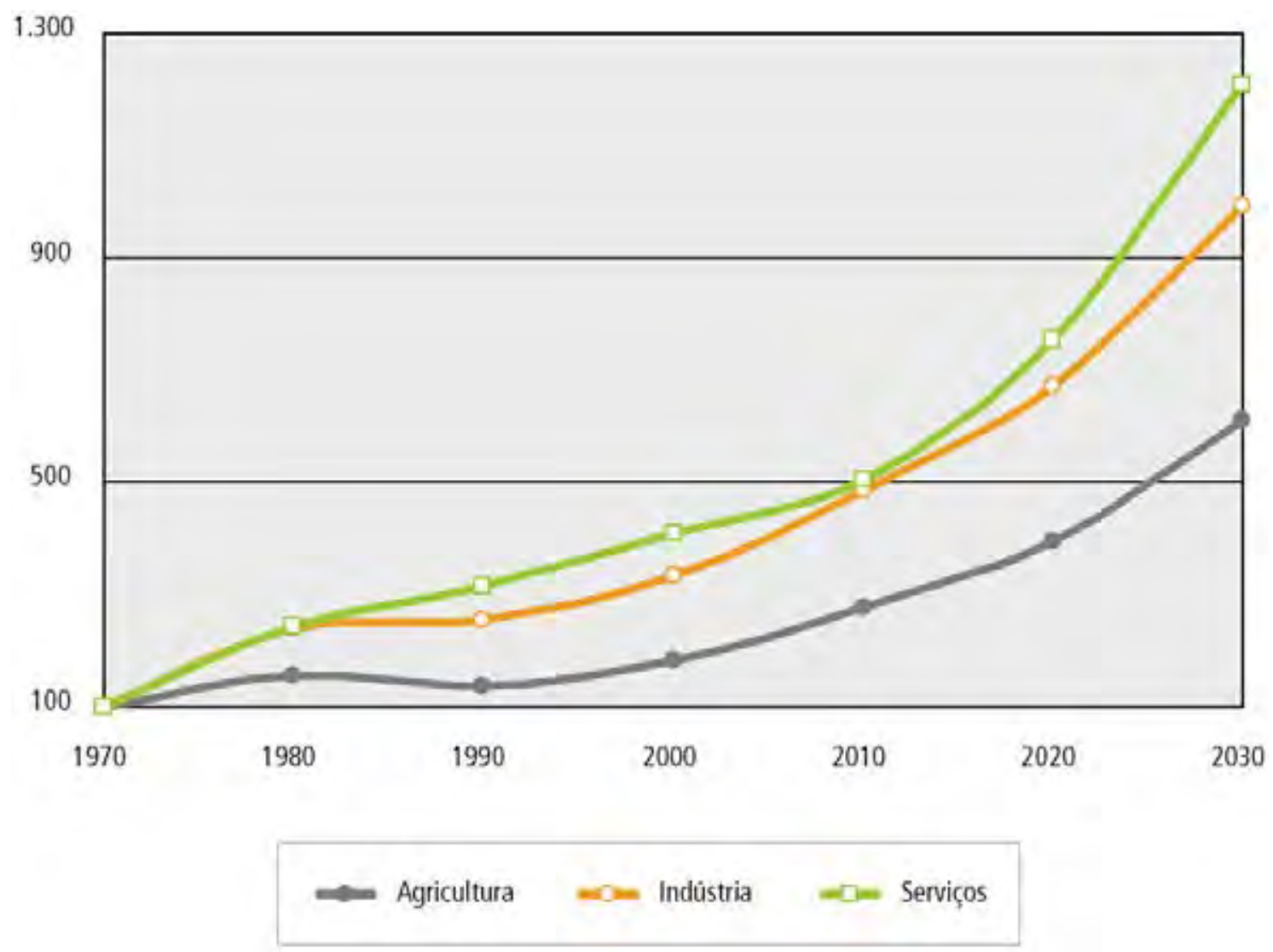

Figura 12: Evolução do PIB por setor

Fonte BEN 2030

Para 2030, é esperado que a mecanização da agricultura atinja cerca de 59\%, sendo que em algumas regiões este índice chegará a 85\% (região Centro-sul), implicando no aumento do consumo de energia para possibilitar este nível de mecanização. Sendo assim, é importante compreender a composição da matriz energética no meio rural e estudar as implicações no consumo energético nacional (BEN 2030, 2010).

A expectativa é que ocorra uma grande demanda de óleo diesel, ficando atrás apenas dos meios de transporte. O uso de biodiesel seria muito importante neste setor, pois iria reduzir a dependência do setor agrícola de uma fonte de energia não renovável (Petróleo) e com tendência de alta, aumentando assim os custos do setor agrícola. Na Tabela 3 é apresentada a estrutura de consumo final esperado para 2030: 
Tabela 3: Estrutura de consumo energético no setor agropecuário por fonte em 2030 (fonte: BEN 2030)

\begin{tabular}{|l|r|r|r|r|}
\hline Origem & $\mathbf{2 0 0 5}$ & $\mathbf{2 0 1 0}$ & $\mathbf{2 0 2 0}$ & $\mathbf{2 0 3 0}$ \\
\hline Diesel de petróleo & 56,6 & 54,5 & 42,1 & 28,1 \\
\hline H-Bio \& Biodiesel & 0 & 8 & 25,9 & 42,2 \\
\hline Eletricidade & 16,1 & 14,5 & 13,9 & 14,7 \\
\hline Lenha & 26,1 & 21,5 & 16,5 & 13,5 \\
\hline Outros & 1,2 & 1,5 & 1,6 & 1,5 \\
\hline
\end{tabular}

Como é possível observar, a utilização esperada de biodiesel deverá crescer consideravelmente no setor agropecuário, mudando a matriz energética rural, hoje predominantemente de origem fóssil.

\subsubsection{Análise energética no meio rural}

É uma análise do agroecosistema, considerando os fluxos energéticos e suas composições. Hesles (HESLES, 1981) quantifica, de maneira estimada, a energia diretamente consumida e/ou indiretamente utilizada em pontos previamente estabelecidos de um sistema produtivo. Neste modelo, a energia é classificada segundo o tipo, fonte e forma:

- Como tipo: energia direta (utilizadas diretamente da natureza) e indireta (tem alguma forma de transformação de energia envolvida).

- Como fonte: Biológica, Fóssil e Industrial.

- Como forma: suas aplicações.

A tabela 4 mostra a relação entre esta classificação: 
Tabela 4: Relação energia direta $X$ indireta

\begin{tabular}{|c|l|l|}
\cline { 2 - 3 } \multicolumn{1}{c|}{} & \multicolumn{1}{c|}{ Energia Direta } & Energia Indireta \\
\hline Biológica & $\begin{array}{l}\text { mão de obra, animais de } \\
\text { trabalho e sementes }\end{array}$ & \\
\hline Fóssil & $\begin{array}{l}\text { óleo diesel, lubrificantes e } \\
\text { graxa }\end{array}$ & \\
\hline Industrial & calcário e agroquímicos & máquinas e implementos \\
\hline
\end{tabular}

A maioria das análises energéticas expressam seus índices em quilocalorias (Kcal). Uma caloria é a quantidade de calor necessária para aumentar de $14,5^{\circ} \mathrm{C}$ para $15,5{ }^{\circ} \mathrm{C}$ a temperatura de um grama de água, sob pressão atmosférica e ao nível do mar. No sistema internacional, é utilizado o Joule.

Neste caso, a conversão pode ser realizada pela fórmula (5):

$$
\begin{gathered}
1 \mathrm{cal}=4,1868 \mathrm{~J} \\
\text { Kcal }=0,0041868 \mathrm{MJ}
\end{gathered}
$$

Durante a análise energética, são calculados vários índices, para avaliar o desempenho do sistema agrícola implantado (HART, 1980). Estes índices são: eficiência cultural, produtividade cultural, eficiência ecológica e energia cultural líquida. 
A eficiência cultural ${ }^{*}$ (EF) é dada pela fórmula (6):

$$
E F=\frac{\text { Saídas úteis }}{\text { Entradas Culturais }}
$$

Onde

$\mathrm{EF}=$ eficiência cultura

Saídas Úteis = Somatória de todas as saídas energéticas geradas no sistema (J) cultura (J)

Entradas Culturais $=$ Somatório de todas as entradas energéticas utilizadas por uma

Se o valor de EF for maior que 1, então o sistema gerou mais energia do que consumiu. Se o valor de EF for subtraído de 1 , tem-se o percentual de eficiência de uma cultura. Por exemplo, suponha que a saída de uma cultura seja de 10000J e o total de gasto energético para produzir seja 8000J. Então, a $E F=10000 / 8000=1,25$. Isto que dizer que para cada $1 \mathrm{~J}$ de energia gasto na cultura, ela produz 1,25J ou 25\% a mais sobre o total investido. Quanto maior este fator, melhor a eficiência de uma cultura*.

A produtividade cultural (PC) é dada pela fórmula (7):

$$
P C=\frac{\text { Quantidade Fisica do Produto }}{\text { Entradas Culturais }}
$$

Onde:

$$
\text { PC = Produtividade cultural (Kg/J). }
$$

\footnotetext{
* Baseado nas notas de aula do prof. Dr. Osmar, na disciplina de análise energética (BUENO, O. C. Notas de aula da disciplina análise energético-econômica de sistemas agroindustriais. Botucatu: Unesp, 2006. Não publicado)
} 
Quantidade Física do Produto = Quantidade em Quilos produzida por uma cultura (kg).

Entradas Culturais = Somatório de toda energia gasta para produzir um produto (J).

A Produtividade Cultural indica quantos quilos de um produto foi produzido aplicando $1 \mathrm{~J}$ de energia. Quanto maior este índice, melhor o sistema da cultura*.

A energia cultural líquida (ECL) é dada por:

$$
E C L=\text { Saídas úteis - Entradas Culturais }
$$

Onde:

ECL= Energia Cultural líquida (MJ)

Saídas Úteis = total de energia gerada por um sistema produtivo (MJ)

Entradas Culturais $=$ Total de energia utilizada em um sistema produtivo (MJ)

Este índice indica a quantidade total de energia gerada pelo sistema e deve ser maior que zero. Se for um numero menor que zero, indica que a cultura gasta mais energia do que consegue produzir*.

Segundo Risoud (1999), o Balanço Energético (BE) é dado pela fórmula (9):

$$
B E=\sum E T-\sum E N R
$$


Onde:

$\mathrm{BE}=$ Balanço energético $(\mathrm{MJ})$

$\mathrm{ET}=$ Energia Total utilizada no sistema $(\mathrm{MJ})$

ENR = Entradas não renovável utilizada no sistema (MJ).

Quanto maior for o valor de BE, menor a dependência de um sistema produtivo com relação ao uso de energias não renováveis.

A eficiência energética (EE) é dada pela fórmula (10):

$$
E E=\frac{\sum E T}{\sum E N R}
$$

Onde:

$\mathrm{EE}=$ eficiência energética

ET = Energia Totais (Somatório de toda energia utilizada no sistema) (MJ)

ENR = Entradas não renovável utilizada na cultura (entrada de energia) cuja origem seja não renovável (MJ)

Quanto maior este índice, menor a dependência que um sistema produtivo tem de energia não renováveis, isto é, melhor a sustentabilidade do sistema produtivo *

O objetivo principal da análise é promover a estabilidade dos ecosistemas (sustentabilidade) e fornecer as informações necessárias à tomada de decisões políticas sobre o uso dos recursos energéticos e direcionamento de novas tecnologias, voltadas a melhorar a perfomance do agronegócio. 
Em muitos estudos comparativos, são analisados dois processos distintos de produção e são comparadas as suas entradas e saídas para determinar a eficiência do método produtivo (ASSENHEIMER, 2009). Nessas análises, muitos fatores são desconsiderados, como por exemplo, a fertilidade "à priori" do solo. Levam-se em conta nos cálculos apenas o balanço energético de uma safra e compara-se com outra safra ou até mesmo o resultado em duas fazendas distintas. Mas se para os cálculos o uso de fertilizantes é considerado, como determinar o real rendimento de uma cultura quando alguns tipos de solo necessitam de mais fertilizantes do que outros para conseguir o mesmo resultado? Neste caso, a analise feita em um solo "melhor" teria vantagens sobre um solo mais pobre, carente de nutriente.

Sendo assim, é necessária uma análise mais aprofundada sobre o assunto, com a criação de uma base centralizada e com dados históricos, comparando o desempenho da produção ao longo de um grande período. Somente assim, podem-se determinar as reais vantagens de um método em detrimento ao outro.

\subsubsection{Conversão energética}

Para determinar o balanço energético de uma cultura é necessário determinar os valores das entradas energéticas envolvidas no sistema: mão de obra, tratores, lubrificantes e combustíveis, maquinários, mudas e sementes, agrotóxicos e fertilizantes.

\subsection{Energia direta}

a) Mão de obra

Alguns autores não consideram a energia do trabalho humano como entrada nos cálculos de balanço energético*, por considerarem pouco relevante no resultado final do processo. Obviamente este não deve ser o caminho a ser seguido, pois, em muitas regiões, o trabalho executado no cultivo de uma espécie é realizada manualmente, consumindo energia 
biológica. Nestes casos, incluir os gastos energéticos com mão de obra torna-se necessário para a correta obtenção dos resultados.

Segundo Seixas (1991), a energia gasta na execução de um trabalho pode ser calculada medindo-se o consumo de Oxigênio $\left(\mathrm{O}_{2}\right)$. Assim, cada litro de $\mathrm{O}_{2}$ consumido pelo corpo equivale a aproximadamente 20J. De acordo com o grau de esforço físico, tem-se uma quantidade diferente energia consumida.

Tabela 5: Classificação do esforço físico diário. Adaptação do trabalho de Seixas (1991).

\begin{tabular}{|l|c|l|}
\hline \multicolumn{1}{|c|}{ Carga de trabalho } & Energia (MJ) & \multicolumn{1}{c|}{ Exemplo de atividade } \\
\hline Leve & até 4,18 & Observação, passeio, retirada de brotos \\
\hline Moderado & 4,18 a 6,68 & Operador de máquinas / Plantio Manual \\
\hline Pesado & 6,68 a 8,36 & Capina, corte de árvores \\
\hline Extra Pesado & Maior que 8,36 & Cavar buracos, escalar árvores, etc. \\
\hline
\end{tabular}

Fonte: Seixas (1991)

Como é possível observar (Tabela 5), o dispêndio energético pode dobrar dependendo da carga de trabalho a ser executada.

b) Insumos

Energia utilizada no balanço energético através do uso de fertilizantes, agrotóxicos, corretivos, etc. Mello (2000) adotou os seguintes valores para os agrotóxicos (Tabela 6):

Tabela 6: Dispêndio calórico dos defensivos agrícolas segundo Mello(2000)

\begin{tabular}{|l|c|}
\hline \multicolumn{1}{|c|}{ Agrotóxicos } & Energia( $\mathbf{~ M J ~} * \mathbf{K g}^{-\mathbf{1}} \mathbf{)}$ \\
\hline Herbicidas & 347,8812 \\
\hline Inseticidas & 311,0792 \\
\hline Formicida em pó & 89,3463 \\
\hline
\end{tabular}

Para os corretivos e fertilizantes, Pimentel (1980b) define: 
Tabela 7: Dispêndio Energético de fertilizantes e corretivos segundo Pimentel(1980b)

\begin{tabular}{|l|c|}
\hline Corretivos e fertilizantes & Energia $\left(\mathbf{~ M J} * \mathbf{K g}^{-\mathbf{1}}\right)$ \\
\hline Calcário & 1,3188 \\
\hline Nitrogenados $(\mathrm{N})$ & 80,3866 \\
\hline Fosfatados $\left(\mathrm{P}_{2} \mathrm{O}_{5}\right)$ & 14,0676 \\
\hline Potássicos $\left(\mathrm{K}_{2} \mathrm{O}\right)$ & 9,0435 \\
\hline
\end{tabular}

c) Combustíveis e lubrificantes

As entradas de combustíveis foram calculadas através do coeficiente energético do combustível multiplicado pela quantidade de combustível utilizada.

d) Animais

Vários autores, a exemplo da energia humana, propõem diferentes valores do consumo energético de um animal. Para fins de cálculo, adotou-se o estabelecido por Pimentel (Pimentel, 1980a), que é de 2000 Kcal por hora.

\subsection{Energia indireta}

É a energia utilizada nos processos industriais de fabricação de maquinários, implementos. Normalmente a energia destes equipamentos entra no cálculo através da depreciação energética.

\subsection{Agronegócio}


Segundo Davis e Goldberg, Agronegócio (AGRIBUSINESS, 2009) é a "soma das operações de produção e distribuição de suprimentos agrícolas, processamentos e distribuição dos produtos agrícolas e itens produzidos a partir deles". Este termo surgiu pela primeira vez em 1957. Agronegócio é, então, toda relação comercial e industrial envolvendo a cadeia produtiva agrícola ou pecuária. Assim, a maneira como as relações de produção e comercialização de produtos na agricultura passa a ser vista como em uma empresa.

O Agronegócio é o maior negócio do Brasil e do mundo, pois gera mais de um terço do Produto Interno Bruto (PIB) e é o responsável por 90\% do saldo positivo da balança comercial do Brasil em 2006, sendo o setor que mais contribui para manter o equilíbrio das contas externas.

A agricultura deve ser vista como o centro dinâmico de uma série de atividades econômicas, que envolvem as atividades de produção agrícola. As funções do agronegócio poderiam ser descritas em sete níveis, a saber:
a) suprimentos à produção (Insumos);
b) produção;
c) transformação;
d) acondicionamento;
e) armazenamento;
f) distribuição;
g) consumo.

Na fase de distribuição vinculam-se os transportadores dos produtos agrícolas, a agroindústria, os agentes financeiros que apoiam a comercialização, os armazenadores e o comércio. O potencial do agronegócio nacional em termos de área cultivável impressiona. A 
área total cultivável do agronegócio no Brasil é de mais de 210 milhões de hectares (24\% do território nacional) (AGRIBUSINESS,2009).

\subsubsection{Conceito}

Agronegócio é toda relação comercial e industrial envolvendo a cadeia produtiva agrícola ou pecuária. No Brasil, o termo agropecuária é usado para definir o uso econômico do solo para o cultivo da terra, associado com a criação de animais. Agronegócio (também chamado de agribusiness) é o conjunto de negócios relacionados à agricultura dentro do ponto de vista econômico. Não se deve confundir agroindústria com agronegócio, pois o primeiro é parte do segundo. Segundo Mendes (Mendes et al, 2007), a agroindústria envolve o processo de produção até o acondicionamento do mesmo, isto é, a produção do produto em si. O agronegócio é muito mais amplo, envolvendo os agentes que produzem os insumos, a produção e transformação, a distribuição dos produtos, aproveitamento energético da biomassa gerada, os agentes econômicos e as políticas públicas que afetam o agronegócio. Enfim, envolve toda a cadeia produtiva deste as indústrias produtoras de insumos até o consumidor final.

Costuma-se dividir o estudo do agronegócio em três partes. A primeira parte trata dos negócios agropecuários propriamente ditos (ou de "dentro da porteira") que representam os produtores rurais, sejam eles pequenos, médios ou grandes produtores, constituídos na forma de pessoas físicas (fazendeiros ou camponeses) ou de pessoas jurídicas (empresas).

Na segunda parte, os negócios à montante (ou "da pré-porteira") aos da agropecuária, representados pelas indústrias e comércios que fornecem insumos para a produção rural. Por exemplo, os fabricantes de fertilizantes, defensivos químicos, equipamentos, etc.

E, na terceira parte, estão os negócios à jusante dos negócios agropecuários, ou de "pós-porteira", onde estão a compra, transporte, beneficiamento e venda dos produtos 
agropecuários, até chegar ao consumidor final. Enquadram-se nesta definição os frigoríficos, as indústrias têxteis e calçadistas, empacotadores, supermercados e distribuidores de alimentos, bancos e políticas públicas que afetam o agronegócio em si.

A produção é o trabalho do agropecuarista, através do cultivo do solo e/ou criação de animais, independentemente do tamanho da área ou método utilizado, com vistas a obtenção de bens de consumo. A transformação é o processo que muda um produto agropecuário em subprodutos, que podem ser bens de consumo ou insumos para outros processos, como o leite, queijos, carnes, embutidos, ração, fios, corantes, entre outros.

\subsection{Sistema de informação}

A partir das necessidades de gerar, armazenar, acessar, analisar e gerenciar as informações, por parte das organizações, surgem os sistemas de informações que dão o suporte para elas. Segundo Laudon (2004, p.7), um sistema de informação pode ser definido tecnicamente como um conjunto de componentes inter - relacionais que coleta, processa, armazena e distribui informações destinadas a apoiar a tomada de decisão, a coordenação e o controle de uma organização.

As empresas precisam de diferentes tipos de sistemas de informação para apoiar suas decisões e as atividades de trabalho nos vários níveis e funções organizacionais. Apesar de cada nível da organização e as áreas funcionais possuírem um sistema específico para atender suas necessidades é definitivamente muito vantajoso que haja algum grau de integração entre os sistemas para que a informação possa fluir facilmente entre diferentes partes da organização.

\subsubsection{Sistema Integrado de Gestão}

Em 1960, surgiram os sistemas corporativos para apoiar a decisão nos processos administrativos, já que na época os softwares disponíveis focalizavam somente o controle de 
inventário (LAUDON, 2004). A partir de 1970, surgiu o sistema MRP, o qual tem por objetivo executar, computacionalmente, as atividades referentes à administração do estoque de conjuntos e de matéria-prima, assim como o controle das etapas produtivas. O MRPII foi criado em 1980. Este sistema suporta funções de produção e estoque e ainda permite que sejam consultados aspectos financeiros como custo e orçamento, além de englobar decisões de como se dará a produção, utilizando-se de quais recursos, permitindo que as informações sejam divididas entre os departamentos. Com a derrubada do muro de Berlim e movimentos políticos no início de 1990, foram abertas as oportunidades à globalização, o que tornou o ambiente mundial competitivo. Como era necessário ampliar a cobertura dos processos da empresa e a pressão competitiva forçava as empresas a uma incessante busca da redução de custos e aumento da eficiência, tornou - se inevitável a expansão e o aprimoramento dos sistemas de empresas e corporações, abrangendo questões estratégicas, logísticas, financeiras e de recursos humanos, passando, assim, a serem chamados ERP (Enterprise Resource Planning).

Os sistemas integrados de gestão fizeram sucesso nos Estados Unidos a partir da década de 1990 e, no Brasil, somente após o ano de 1996, com o principal objetivo de integrar as mais diversas áreas das empresas e fornecer informações atualizadas de cada setor.

Para Cunha (apud SOUZA; SACCOL, 2003, p. 245), um Sistema de informação é um modelo de gestão baseado em sistemas corporativos de informação que visam integrar os processos de negócio da empresa e apoiar decisões estratégicas. O modelo desse sistema tem uma abrangência de atuação que envolve várias entidades de negócios, integrando a cadeia de suprimentos, fornecedores a clientes, buscando endereçar as questões de competitividade das organizações empresariais.

Todas as informações geradas dentro desse sistema são armazenadas e relacionadas em um banco de dados único, mas nada impede que sejam utilizados bancos de dados diferentes. Entretanto, esses se relacionarão dentro daquele. Além disso, com as informações integradas, é possível a criação de relações entre as diferentes funções e departamentos da empresa. Esse sistema de gestão pode ser utilizado para fazer uma ligação entre as necessidades de atendimento da demanda e as necessidades tanto de recursos materiais quanto humanos, possibilitando reduções de custo e flexibilidade em relação aos processos produtivos, permitindo assim que se aumentem a eficácia e a eficiência na programação da produção. 
Segundo Stamford (apud SOUZA; SACCOL, 2003, p. 245), um Sistema de Informação possibilita um fluxo de informações único, contínuo e consistente por toda a empresa sob uma única base de dados. É um instrumento para a melhoria de processos de negócio, orientado por esses processos e não pelas funções e departamentos da empresa, com informações em tempo real. Ele permite visualizar por completo as transações efetuadas pela organização, desenhando amplo cenário de seus processos de negócios.

\subsubsection{Redes}

Segundo Tanenbaum (TANENBAUM, 1997), uma rede de computadores consistem em dois ou mais equipamentos interligados de modo a possibilitarem o compartilhamentos das informações ou serviços. Um grande exemplo desse conceito é a Internet, que é um amplo sistema de comunicação que interliga muitas redes de computadores.

Os primeiros experimentos de rede ocorreram em 1940, quando George Stibitz utilizou um computador model K da faculdade de Dartmouth (na Nova Hampshire) para enviar dados através de um teletipo à uma calculadora em Nova Iorque e receber os resultados posteriormente.

Em 1965, Lawrence Roberts e Thomas Merril realizaram experiências de conexão utilizando uma linha telefônica discada de baixa velocidade, fazendo a conexão entre os centros de pesquisa em Massachusetts e outro na Califórnia.

A Internet surgiu dos esforços de ARPA (Advanced Research Projects Agency), uma agência ligada ao departamento de defesa americano, que tinha como objetivo criar uma rede de comunicação militar. Em 1969 esta rede interligava quatro universidades: Universidade da Califórnia em Los Angeles (UCLA), Stanford, Santa Bárbara e Utah.

Este modelo de rede evoluiu e deu origem à Internet. A Internet é hoje a maior rede de ligação entre computadores, conectando uma estação a qualquer lugar do mundo, democratizando o conhecimento.

A Internet utiliza o modelo cliente-servidor. Um servidor é um sistema que fornece serviços a uma rede de computadores (Como por exemplo, transferência de arquivos, correios 
eletrônicos, bancos de dados, impressão, etc). Os computadores que acessam os serviços oferecidos por um servidor são chamados de Clientes.

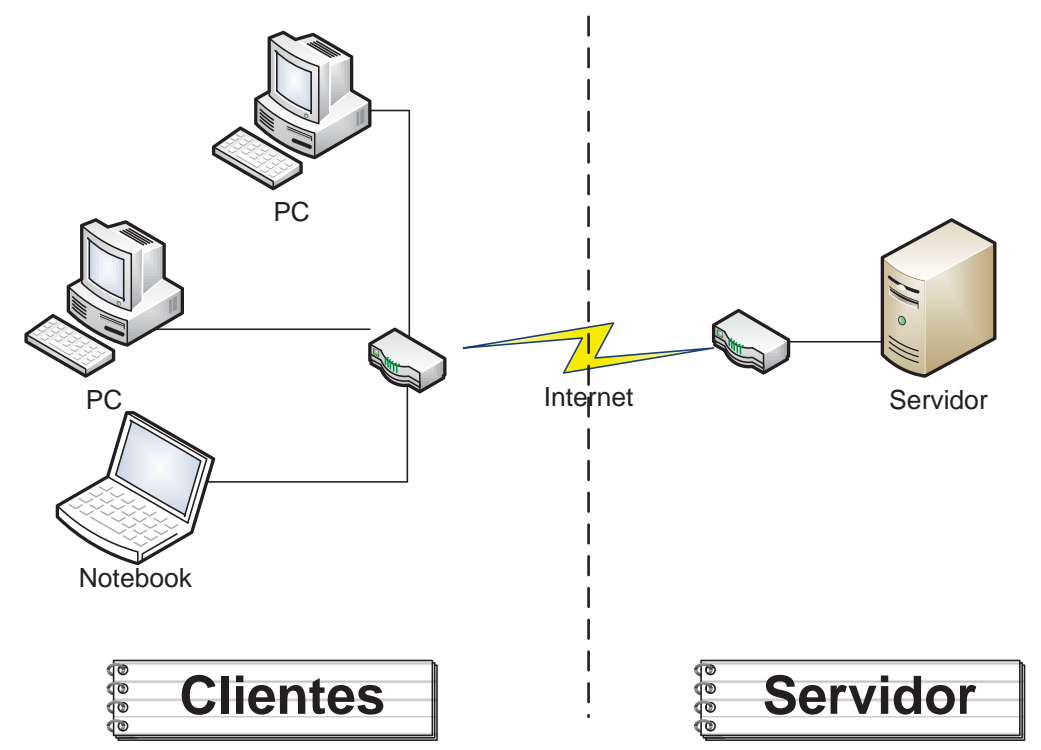

Figura 13: Arquitetura Cliente- Servidor

Existem vários tipos de servidores, mas para que haja a comunicação entre o cliente e o servidor é necessário estabelecer um protocolo de comunicação entre eles. No caso da Internet, este protocolo é conhecido como protocolo de transporte/Protocolo de endereçamento (TCP/IP).

Entre os vários serviços disponíveis na Internet, um deles vem se destacando: A utilização de web services para as transferências de dados.

\subsubsection{Web services}

Inicialmente, o uso da Internet limitava-se a troca de arquivos, mensagens e páginas web (DEITEL, 2005). Com a sua evolução, novos serviços surgiram e uma nova abordagem tem sido apregoada na web: A computação em Nuvem. A ideia central desta abordagem é que 
as empresas irão comprar suas tecnologias de informação como serviços providos através da Internet.

Diferente de um site comum, feito para que o usuário possa interagir com a informação, os web services conectam diretamente as aplicações. Assim, uma aplicação pode interagir diretamente com outra, mesmo sendo desenvolvido em outra linguagem, pois o web service é padronizado em uma plataforma aberta.

Eles permitem que duas aplicações se comuniquem através do envio de informações em formato XML (protocolo de transmissão de dados aberto). Assim, uma aplicação pode chamar outra para executar alguma tarefa para ela, mesmo que este serviço esteja a milhares de quilômetros de distância.

Um web service pode ser um grande aliado para as corporações, pois um serviço pode ser disponibilizado remotamente para uma infinidade de clientes.

\subsection{Ferramentas de desenvolvimento}

Desde os primórdios, o homem tem a necessidade de usar números, elaborar cálculos, e obter soluções para que sua existência se torne mais simples. Dito isso, há muito tempo atrás criaram a primeira máquina de fazer cálculos: o ábaco.

No meio do século passado, criaram-se os primeiros computadores, capazes de realizar cálculos básicos (TANENBAUM, 2003). Uma característica marcante era que o software (programa responsável por "dizer" o que a máquina deve fazer) vinha junto com hardware e não poderiam ser desmembrados, tendo o computador uma função fixa e pré-definida.

Com a evolução dos computadores e a ampliação da capacidade de processamento, logo o software passou a ser independente do hardware, possibilitando que o computador executasse mais de uma função e que a mesma poderia ser programada. Surgiram, então, as primeiras linguagens de programação.

Para facilitar a vida dos programadores, o software foi dividido em duas partes: um software básico (responsável por controlar e gerenciar o hardware, apresentando uma camada mais simples aos programas, conhecido como Sistema Operacional) e um software aplicativo 
(que desempenha alguma função específica, como por exemplo, o Microsoft Word). Na figura 14 têm-se as divisões de um sistema computacional.

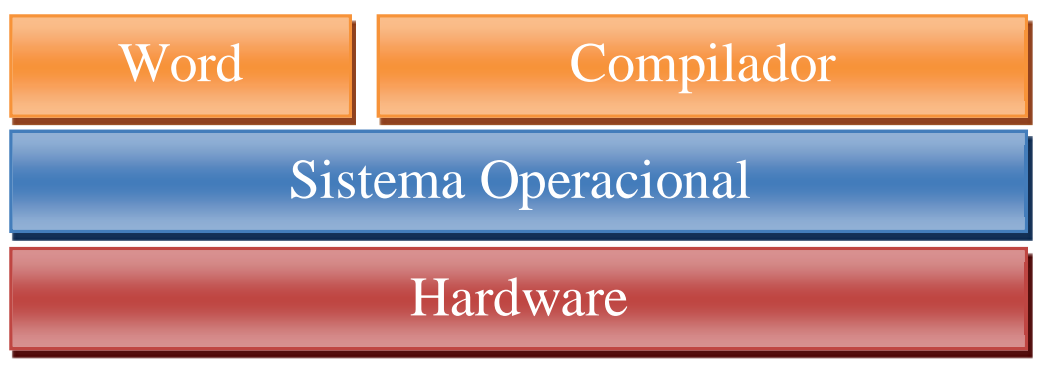

Figura 14: Arquitetura do sistema operacional

Assim, com uma maior liberdade e a redução de custos do hardware, popularizou-se as linguagens de programação e os compiladores, que eram softwares que geravam outros programas, dependendo da sequência previamente programada.

As primeiras linguagens de programação eram bastante complicadas e dependiam do hardware e do sistema operacional que estava instalado (TANENBAUM, 2003). Assim, linguagens como o Assembler e o Ada surgiram. Com a evolução, surgiram as linguagens de alto nível, onde a interação com o hardware era bem menor e as instruções eram bem mais intuitivas, facilitando a programação. Algumas destas linguagens foram o Cobol, o Fortran, o Pascal e a linguagem C.

Posteriormente, surgiu uma nova geração de linguagens, que era declarativa (especificase para o computador "o que será feito" e não "como será feito"), composta por códigos que poderiam ser reutilizados, aumentando o desempenho na confecção dos programas. Assim surgiram linguagens como o Visual Basic e o Delphi.

\subsubsection{UML}

A Unifield Modeling Language (UML) é uma linguagem de modelagem não proprietária. A UML não diz o que fazer e como projetar o sistema, mas ajuda o desenvolvedor a visualizar o sistema que será construído através de um conjunto de diagramas 
padronizados. O objetivo principal da UML é documentar a especificação de um sistema, de maneira a facilitar a visualização lógica do sistema.

A UML surgiu em 1996 na Rational (UML, 2010). Basicamente possui os seguintes diagramas:

- Diagrama de Caso de Uso: mostra os atores (pessoas ou outros usuários do sistema), casos de uso (os cenários onde eles usam o sistema), e seus relacionamentos;

- Diagrama de Classe: mostra as classes e os relacionamentos entre elas;

- Diagrama de Sequência: mostra os objetos e uma sequência das chamadas do método feitas para outros objetos;

- Diagrama de Colaboração: mostra os objetos e seus relacionamentos, colocando ênfase nos objetos que participam na troca de mensagens;

- Diagrama de Estado: mostra os estados, mudanças de estado e eventos num objeto ou uma parte do sistema;

- Diagrama de Atividade: mostra as atividades e as mudanças de uma atividade para outra com os eventos ocorridos em alguma parte do sistema;

- Diagrama de Componente: mostra os componentes de programação de alto nível;

- Diagrama de Distribuição: mostra as instâncias dos componentes e seus relacionamentos;

- Os Diagramas de Entidade-Associação: mostram os dados e as relações e as restrições entre os dados.

Apesar da enorme variedade de diagramas, dependendo da aplicação a ser desenvolvida, nem todos são usados no projeto. Para este projeto, foi utilizado o diagrama de classes.

\subsubsection{Delphi}

É um ambiente de desenvolvimento de aplicações orientado a objetos, que permite a criação de aplicações para sistemas operacionais, que podem ser utilizada tanto para o 
desenvolvimento de aplicações cliente/servidor, quanto para aplicações de uso genéricas, como editores de textos, planilhas eletrônicas, etc.

Além disso, ele utiliza um dialeto da linguagem Object Pascal, tem os seus componentes definidos como objetos permitindo heranças, permite a criação de novos componentes na própria linguagem, o acesso a banco de dados é fácil e possui um ambiente de depuração integrado facilitando a solução dos erros de programação que poderão surgir durante o desenvolvimento.

O Delphi pode ser visto como uma ferramenta moderna, de alta produtividade e que permite construir aplicações rápidas e otimizadas.

\subsubsection{Georreferenciamento}

Georreferenciar uma imagem ou mapa é tornar suas coordenadas conhecidas em um sistema de referências global. Georreferenciar um imóvel significa descrever um imóvel em suas características, limites, confrontações, levantando as coordenadas de cada extremidade da propriedade.

Atualmente, a lei 10.267 tornou obrigatória a georreferenciação dos imóveis (CASA CIVIL, 2010) em casos de alteração de matrícula da escritura (como mudança de titularidade, remembramento, desmembramento, parcelamento, modificação de área, etc...), utilização da propriedade para fins de financiamento ou hipoteca. É necessário um memorial técnico assinado por um profissional habilitado, contendo as coordenadas dos vértices definidores dos limites da propriedade, georeferenciadas nas coordenadas no Sistema geodésico Brasileiro. A pena para o descumprimento é uma multa de R\$1.000,00 (Um mil reais) por dia.

Esta mesma lei foi regulamentada pelo decreto 4.449 de 30 de outubro de 2002 que foi alterado pelo decreto 5.570 de 31 de outubro de 2005, criou o Cadastro Nacional de Imóveis Rurais (CNIR), que é uma base de dados gerenciadas pelo Instituto Nacional de Colonização e Reforma Agrária (INCRA) e pela Receita Federal a respeito das propriedades rurais e suas características.

Assim, toda a propriedade rural deverá possuir suas coordenadas registradas em uma base nacional, para futuras consultas públicas. 


\subsubsection{TatukGis}

O TatukGIS é um SDK (Software Development Kit) para o desenvolvimento de aplicações GIS (Geografical Information System) utilizando linguagens orientadas a objeto, como a linguagem object pascal (utilizada pelo Delphi). Oferece funcionalidades de análise de dados para gerar mapas temáticos com base nos valores de dados GIS das tabelas de atributos, além de fornecer ferramentas de medição de distância, área e perímetro. 


\section{MATERIAL E MÉTODOS}

Para o cálculo do balanço energético no meio rural foi montado um sistema de Informação, desenvolvido em Delphi. O software abrange o agronegócio especializado no plantio de culturas. Neste software não foram consideradas outras atividades, como a criação de animais.

Os dados necessários sobre o funcionamento de um estabelecimento rural foram colhidos em duas propriedades (uma em Lins-SP e outra em Oscar Bressane-SP).

A primeira propriedade foi a fazenda Santa Terezinha, fundada em 1980 por Eduardo Leonildo Michelete. Está localizada na estrada Vicinal Lins-Molevade e atua na plantação e comercialização de laranja tipo pera. Na referida fazenda encontram-se 25 mil pés de laranja, sendo 20 mil em produção e 5 mil plantados recentemente.

O solo da fazenda para plantação de laranja é siltoso, profundo e bem drenado, pois o solo raso é sujeito a encharcamento. As operações de preparo de solo passam por desmatamento, destoca, queima, controle de formigas e cupins, aplicação de corretivo, aração e gradagens.

Com o solo preparado, ele fica pronto para a plantação das mudas. O tempo necessário entre o plantio da muda até a primeira colheita é de aproximadamente 4 anos. Durante este período, são necessários alguns tratos culturais, como eliminação de brotações, poda de ramos secos e doentes, limpeza do tronco e ramos, capinação do mato, etc. A maioria destes processos são feitos manualmente por trabalhadores da fazenda.

A colheita é feita artesanalmente, requisitando grande quantidade de mão de obra e tempo. O controle de pragas é realizado através de pulverização de agrotóxicos. 
A segunda propriedade é o sítio Yanai em Oscar Bressane- SP, região de Marília - SP, no sentido de Assis - SP. Foi fundada em 1942 pela família Yanai, imigrantes japoneses, que plantam e comercializam vários tipos de hortaliças e frutas, principalmente pimentão, tomate, vagem e mamão. A principal fonte de renda é o tomate, com cerca de 15.000 mudas em uma área de um hectare, que levam de dois e três meses para começar a produzir. O solo é siltoso, profundo, bem drenado e pouco ácido e o clima é bem ameno, favorável a produção de tomate.

As operações de manejo desta cultura são controle de insetos, aplicação de corretivos e adubação, aração e gradagem, capinação, controle de pragas e colheita. Além disso, é realizada a irrigação duas vezes por semana, que poder feita com o trator (tanque) ou por girador. Toda a colheita é realizada manualmente para não danificar os frutos.

\subsection{Materiais}

Para realização dos cálculos, as entradas energéticas foram divididas em direta (biológica do trabalho humano e dos animais, energia dos fertilizantes, corretivos e agrotóxicos, energia elétrica e energia dos combustíveis) e indiretas (oriundas da depreciação energética das máquinas, implementos e edificações).

Os tratores, caminhões e maquinários foram considerados produtos manufaturados, portanto considerados fontes indiretas. Como estes produtos industrializados eram compostos por uma carcaça de metal (industrial), por partes plásticas e pneus (Fóssil), os mesmos foram criados como objetos compostos (Misto) e para calcular a energia utilizada é necessário desmembrar os diversos tipos de entradas, para calcular a energia utilizada. Assim, um objeto pode ser um agrupamento composto por um ou mais objetos.

As atividades agrícolas foram agrupadas inicialmente em preparo de solo, plantio, manejo e colheita o detalhamento das operações e apresentado abaixo:

a) Preparo do solo: Operação normalmente realizada com o auxilio de um trator com pneus, e a utilização de um implemento agrícola (carretas, arado, grade, roçadeira) a fim de prepara o solo para o plantio. Nesta fase procura-se realizar a descompactação do solo e a correções. Em alguns casos podem ser realizadas operações de controle de pragas. 
b) Plantio: Operação que pode ser realizada tanto manualmente como com auxilio de maquinário tocado por um trator.

c) Manejo: Operações como a capinação, pulverização, adubação e desbrota. Pode ser tarefas mecanizadas ou realizadas manualmente.

d) Colheita: Operação mecanizada ou manual para colheita dos produtos, transporte e armazenagem.

\subsection{Métodos}

Nesta análise, as entradas energéticas foram classificadas e quantificadas conforme a fonte. O diagrama (Figura 15) mostra a relação entre os diversos tipos de energia.

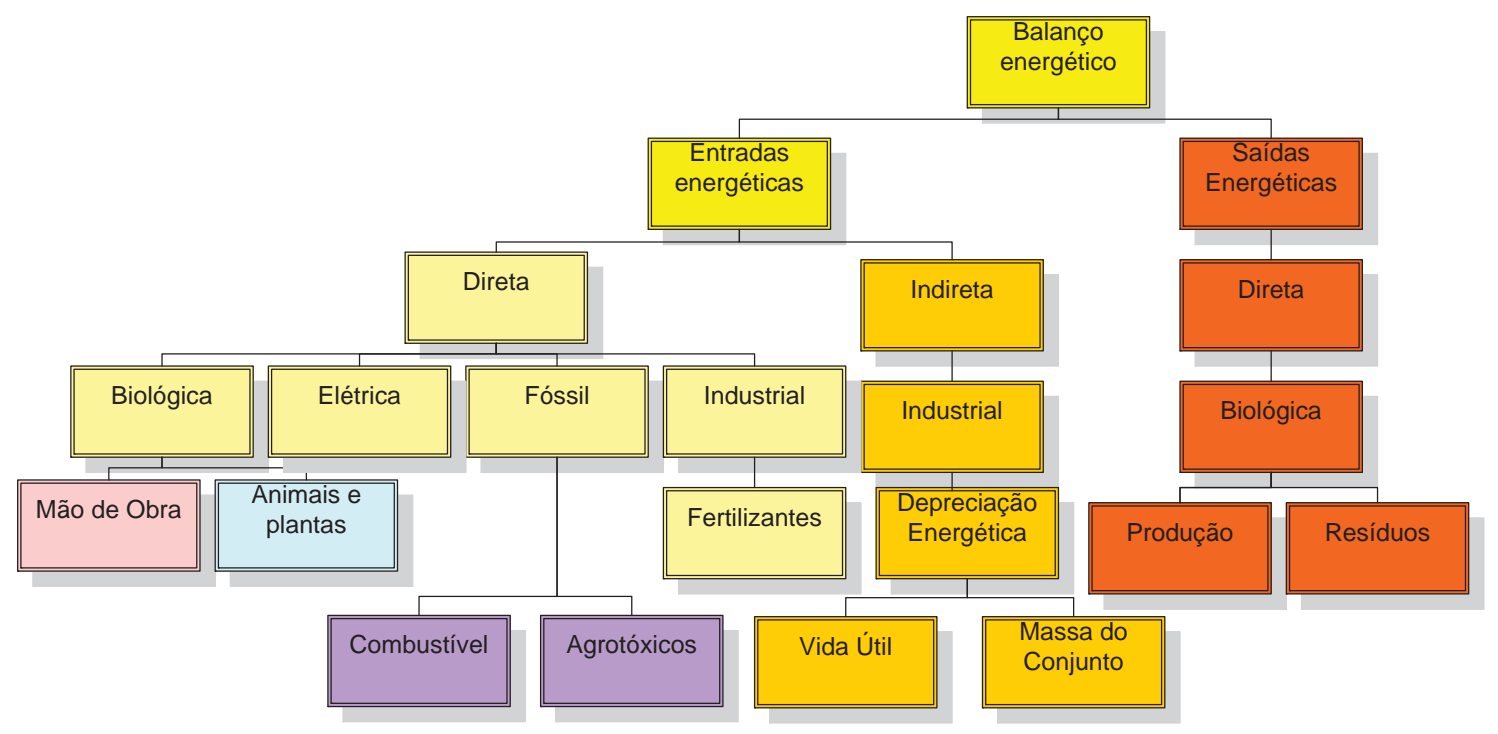

Figura 15: Classificação das fontes energéticas

Fonte: elaborado pelo autor

Para realização dos cálculos, o fluxo das entradas energéticas externas foi dividido em energia direta e indireta. A energia gasta com a mão de obra do manejo da produção foi 
considerada energia biológica. Também foram consideradas as energias gastas com o transporte interno dos insumos e produtos.

A energia direta foi dividida em:

- Biológica: Oriunda dos animais, plantas e adubação orgânica, etc.

- Elétrica: Energia elétrica utilizada durante a produção, como por exemplo, para movimentar as bombas de irrigação.

- Fóssil: Energia vinda do petróleo e seus derivados, como os agrotóxicos, pneus, etc.

- Industrial: Energia vinda de um produto industrializado que tem o seu valor energético utilizado diretamente na cultura, como por exemplo, os fertilizantes e o calcário.

A energia indireta é aquela que o valor energético não é utilizado diretamente na produção, mas sim calculado através da depreciação energética, como por exemplo, os tratores e equipamentos.

No cálculo das saídas energéticas foram consideradas as energias obtidas no resultado produtivo da cultura (colheita) e os resíduos produtivos que poderiam ser utilizados (bagaço, esterco, etc...). Não foi considerado nos cálculos a energia retirada do solo e a fertilidade do mesmo, que varia de região para região. Portanto, a degradação ou a recuperação do solo pelo uso de corretivos e fertilizantes não foram consideradas no cálculo. Somente será considerada a energia total dos fertilizantes utilizados. Se parte deste ficou no solo, não será computado pelo sistema.

\subsubsection{Conversão energética}

As conversões energéticas foram realizadas utilizando o método analítico de cálculo e as suas equações são apresentadas nos tópicos a seguir. 


\subsubsection{Trabalho humano}

Segundo Fluck (1985), itens como moradia, transporte, educação e vestuários não devem ser quantificados nos cálculos.

Para o cálculo do dispêndio energético humano foi considerado inicialmente o Gasto Energético no Repouso (GER) e como o mesmo variava de acordo com o peso, altura e idade da pessoa ${ }^{2 *}$, adotou-se (11):

$$
\operatorname{GER}=66,5+(13,75 * \mathrm{M})+(5 * \mathrm{~A})-(6,78 * \mathrm{I})
$$

Onde:

$$
\begin{aligned}
& \text { GER = Gasto Energético no Repouso (Kcal) } \\
& \text { M = Massa(Kg) } \\
& \text { A = Altura (cm) } \\
& \text { I = Idade (anos) }
\end{aligned}
$$

Assim, uma pessoa de massa corporal de $90 \mathrm{Kg}$, com 1,90m de altura e 31 anos de idade teria o GER igual à 2.043,82 kcal.

Também foi adotado que um indivíduo teria gastos diferenciados de energia de acordo com o tipo de trabalho realizado. Para um individuo dormindo, utilizou-se a divisão do GER pelo período de tempo (24 horas). Logo, a necessidade energética de uma pessoa em repouso (NEr) é de (12) :

$$
\mathrm{NEr}=\frac{\text { GER }}{\text { período }}
$$

\footnotetext{
* 2 Notas de aula do professor Dr. Osmar (BUENO, O. C. Notas de aula da disciplina análise energéticoeconômica de sistemas agroindustriais. Botucatu: Unesp, 2006. Não publicado)
} 
Onde:

$\mathrm{NEr}=$ Necessidade Energética em Repouso $(\mathrm{Kcal} / \mathrm{h})$

GER = Gasto Energético no Repouso (Kcal)

Período = tempo executando a atividade (h)

Quando este indivíduo exerce alguma forma de atividade física leve (NEl), o aumento no consumo energético em relação ao repouso é de 50\% (fórmula 13). Um exemplo disso são as atividades diárias, e trabalho leve.

$$
\mathrm{NEl}=\frac{\mathrm{GER}}{\text { período }} * 1,5
$$

Onde:

$\mathrm{NEl}=$ Necessidade energética em atividade física leve $($ Kcal /h)

GER = Gasto Energético no Repouso (Kcal)

Período = tempo executando a atividade (h)

Agora, se o mesmo indivíduo executar um serviço pesado (NEp), o fator é de 100\% de necessidade energética em relação ao GER. Assim, temos (14):

$$
\mathrm{NEp}=\frac{\mathrm{GER}}{\text { período }} * 2,0
$$

Onde:

NEp = Necessidade energética em um serviço pesado (Kcal /h)

GER = Gasto Energético no Repouso (Kcal)

Período = tempo executando a atividade (h) 
Sendo assim, a necessidade energética (NEi) de um indivíduo é dado pela formula 15:

$$
\mathrm{NEi}=\frac{\mathrm{GER}}{\text { período }} * \mathrm{FT}
$$

Onde:

GER = Gasto Energético de uma pessoa em Repouso (Kcal)

Período $=$ Tempo que o indivíduo executou a atividade $(\mathrm{h})$

FT = Correção de acordo com o tipo de trabalho a ser realizado.

A Tabela 8 mostra esta relação. Estes fatores foram calculados através da adaptação do trabalho de Seixas(1991):

\section{Tabela 8: Fator de Trabalho}

\begin{tabular}{|l|r|}
\hline \multicolumn{1}{|c|}{ Fator trabalho } & \multicolumn{1}{c|}{ valor } \\
\hline Repouso & 1 \\
\hline Trabalho leve & 1,5 \\
\hline Atividades seculares & 1,5 \\
\hline Trabalho pesado & 2 \\
\hline Trabalho Extra Pesado & 2,5 \\
\hline
\end{tabular}

Fonte: Seixas, 1991

Para um indivíduo apresentado no inicio deste tópico, que exerce 8 horas de atividade profissional leve, tem-se:

Tabela 9: Exemplo de calculo de gasto energético

\begin{tabular}{|l|c|r|r|}
\hline \multicolumn{1}{|c|}{ Calculo do trabalho } & $\begin{array}{c}\text { Energia } \\
\text { (cal)(h-1) }^{-1}\end{array}$ & $\begin{array}{c}\text { Horas } \\
\text { Ocupadas (h) }\end{array}$ & \multicolumn{1}{c|}{ Total(Kcal) } \\
\hline Sono (8h) & 84,31 & 8 & 674,49 \\
\hline Ocupação Profissional (8h) & 126,47 & 8 & 1011,74 \\
\hline Não Profissional (8h) & 126,47 & 8 & 1011,74 \\
\hline \multirow{2}{*}{ Total } & $\mathbf{2 4}$ & $\mathbf{2 6 9 7 , 9 7}$ \\
\cline { 2 - 4 }
\end{tabular}

Fonte: Elaborado pelo autor. 
Assim, em 24 horas (um dia), foram considerados que uma pessoa terá 8 horas de sono, 8 horas exercendo alguma atividade profissional e terá 8 horas para realização das tarefas cotidianas, totalizando 2.697,97 Kcal.

\subsubsection{Máquinas e equipamentos.}

Para os cálculos energéticos dos maquinários (energia indireta, como por exemplo, o trator) foi realizada a depreciação energética proposta por Comitre (1993).

$$
\mathrm{CE}=\frac{\mathrm{ME}+\mathrm{PR}+\mathrm{CP}+\mathrm{PM}}{\mathrm{VU}}
$$

Onde:

$$
\begin{aligned}
& \mathrm{CE}=\text { Depreciação }((\mathrm{MJ} * \mathrm{Kg}) / \mathrm{h}) \\
& \mathrm{ME}=\text { Massa das máquinas e equipamentos(Kg) * Coeficiente Energético (MJ) } \\
& \mathrm{CP}=\text { Número de pneus*Massa(Kg)*Coeficiente Energético de Referencia(MJ) } \\
& \mathrm{PR}=\text { Representa o percentual de reparos }(5 \% \text { de } \mathrm{ME}) \\
& \mathrm{PM}=\text { Representa o percentual de manutenção }(12 \% \text { de }(\mathrm{ME}+\mathrm{PR}+\mathrm{CP})) \\
& \mathrm{VU}=\text { representa a vida útil do equipamento em horas }(\mathrm{h}) .
\end{aligned}
$$

Para fins de cálculo, assumiu-se que o Coeficiente Energético para os implementos era a quantidade total de energia dividido pela massa do objeto. Tem-se com isto os seguintes valores de CE: 
Tabela 10: Tabela de CE médio.

\begin{tabular}{|l|r|}
\hline \multicolumn{1}{|c|}{ Equipamento } & CE $\left(\mathbf{M c a l}^{*} \mathbf{t}^{\mathbf{1}} \mathbf{)}\right.$ \\
\hline Pneus & $20.500,00$ \\
\hline Implementos Primários (até plantio) & $2.061,00$ \\
\hline Implementos Secundários (após plantio) & $1.995,00$ \\
\hline
\end{tabular}

Fonte: Doering (1980).

\subsubsection{Combustíveis.}

Para os cálculos que envolve o uso de maquinários, utilizou-se por padrão que a participação energética seria o Coeficiente Energético (CE) multiplicado pelo consumo de combustível (ou derivados).

Tabela 11: Coeficiente Energético dos derivados de petróleo

\begin{tabular}{|c|c|}
\hline CE médio & Energia( Mcal* $\mathrm{I}^{-1}$ ) \\
\hline Combustível (Diesel) & 10,4424 \\
\hline
\end{tabular}

Sendo assim, a equação (17) ficaria:

$$
\mathrm{Ecomb}=\mathrm{CE} * \mathrm{Co}
$$

Onde:

Ecomb = Energia dos combustíveis (Mcal)

$\mathrm{CE}=$ Coeficiente energético do Combustível (Mcal/L)

Co = Quantidade de combustível utilizado durante a realização de uma tarefa (L). 


\section{RESULTADOS E DISCUSSÕES}

Para a realização deste trabalho, modelou-se um sistema de informação utilizando a tecnologia de orientação a objetos do Delphi. O sistema foi dividido em duas partes: Um software aplicativo Cliente, responsável pelo controle econômico e energético nas máquinas dos produtores rurais e um Servidor, responsável pelo mapeamento energético Brasileiro.

A Figura 16 apresenta a estrutura básica do sistema de informação construído:

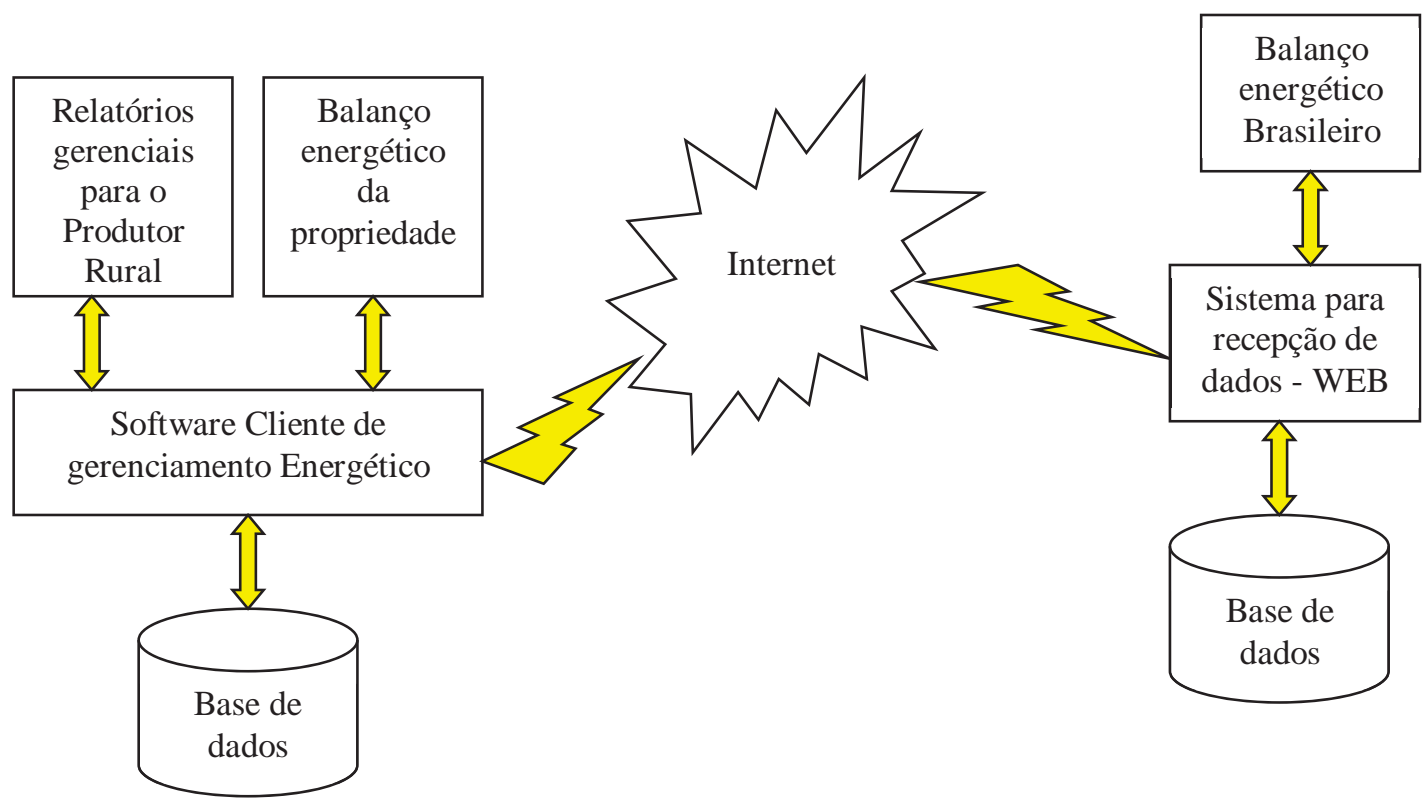

Figura 16: Modelo computacional implementado.

Como se pode observar, os dados oriundos dos clientes são enviados ao servidor pela conexão web. Os dados enviados já se encontram previamente processados na máquina local (economizando recursos do servidor) e serão armazenados em uma base única, contendo os dados de diversas localidades, permitindo gerar gráficos gerencias sobre a demanda energética 
por região e o levantamento da composição energética de entradas e saídas (matriz energética), podendo-se estimar a eficiência energética nas diversas regiões.

O sistema de informação é modular. A estrutura pode ser vista na Figura 17:

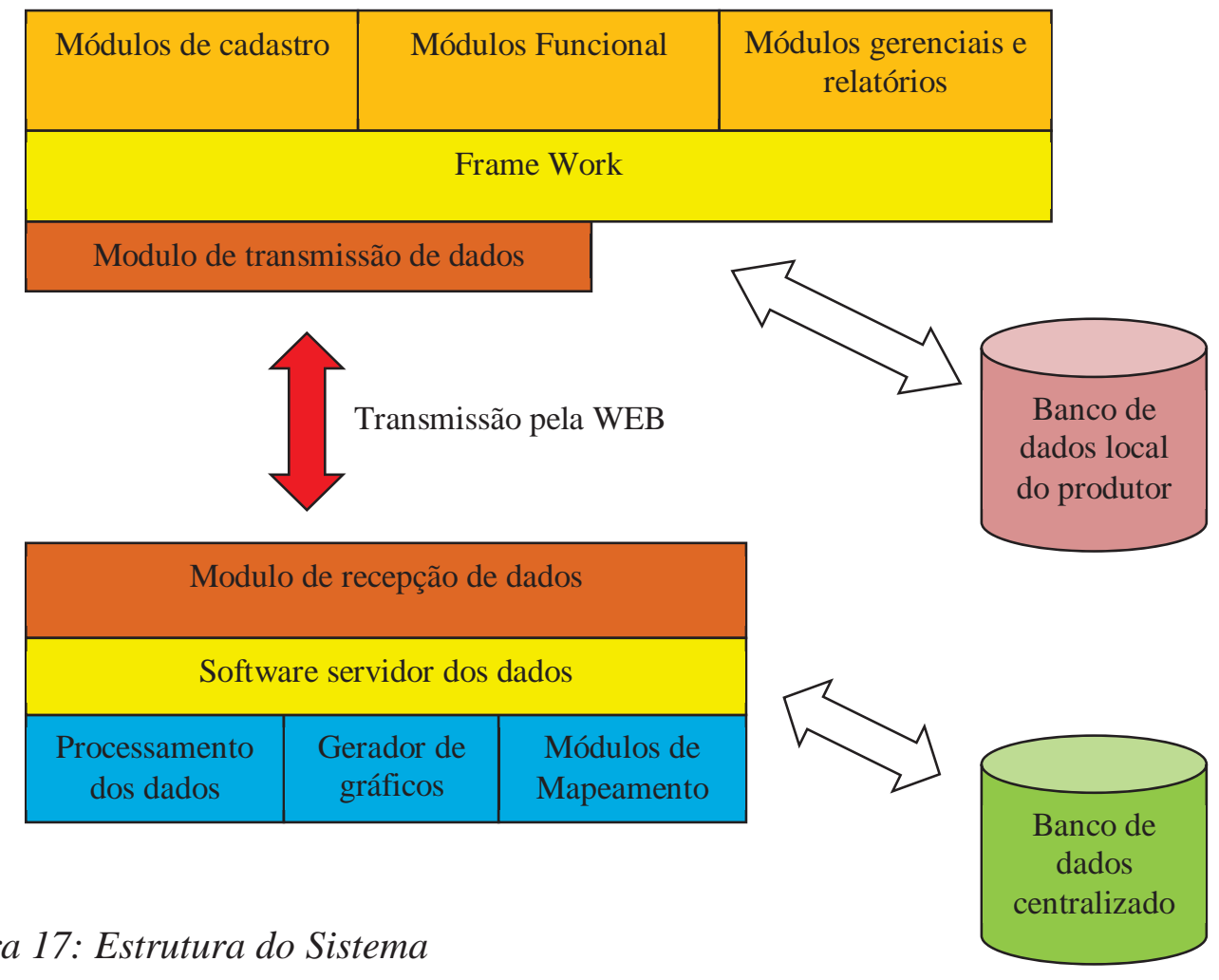

Figura 17: Estrutura do Sistema

Os dados colhidos nas estações são, basicamente, um resumo da utilização energética/financeira nas diversas culturas. Ao fechar um ciclo produtivo, os dados são enviados para o servidor, aguardando o processamento. Quando os dados chegam ao servidor, é identificado a sua origem (região) e os dados são enviando para serem plotados em um gráfico de demanda energética, segundo uma classificação inicial em energia de origem biológica, industrial e fóssil. Com base nesta classificação, será construída a avaliação da matriz energética.

Para realizar a transmissão dos dados, foi utilizado a Internet (via protocolo TCP/IP), enviando dados para um webservice, responsável pela recepção dos dados.

A vantagem de implementar um servidor central é que os dados seriam centralizados e as analises podem ser feitas sobre diversas culturas e regiões, possibilitando uma análise mais 
clara sobre a demanda energética e o balanço energético das diversas culturas encontradas no Brasil.

Com base nestas analises, pode-se definir novos rumos para a matriz energética brasileira, de tal forma a aumentar a sustentabilidade dos negócios agrícolas.

\subsection{Modelo computacional}

Utilizando a abordagem de modelagem UML, construiu-se um modelo em Delphi. O software possui as seguintes características:

- Trabalha com diversos tipos de culturas;

- Possibilita o controle financeiro do empreendimento rural;

- Realiza a análise energética do agronegócio;

- Possibilita um controle claro dos recursos utilizados nas diversas culturas realizadas no empreendimento rural.

No próximo tópico será apresentada a modelagem do sistema em UML.

\subsection{Modelagem UML}

Na Figura 19 é apresentado o diagrama de classes do sistema desenvolvido (módulo cliente). Como se pode observar, o sistema compreende aos cálculos energéticos de uma propriedade rural, podendo realizar diversas atividades de cultivo e controlar cada uma delas. Não foi compreendido neste sistema o controle das atividades ligadas à criação de animais (pecuária).

No Servidor, optou-se por uma estrutura de banco de dados mais simples, pois muitos dados não eram relevantes quando observados em modo macro (global) e o volume de dados seria muito grande, inviabilizando o processamento em tempo real. Dados como consumo de um determinado produto não serão exportados, mas sim a quantidade total de um determinado tipo de energia. Sendo assim, na Figura 18 é apresentado o diagrama de classes do servidor. 
Não é armazenado no servidor dados referentes às propriedades (proprietários, localização, etc), dados financeiros e consumos individuais de produtos (por exemplo, quantidade de um determinado adubo utilizado), mas serão processados dados como a quantidade total de energia fóssil utilizada em uma fase de uma cultura ou quantidade total de energia gasta por uma cultura.

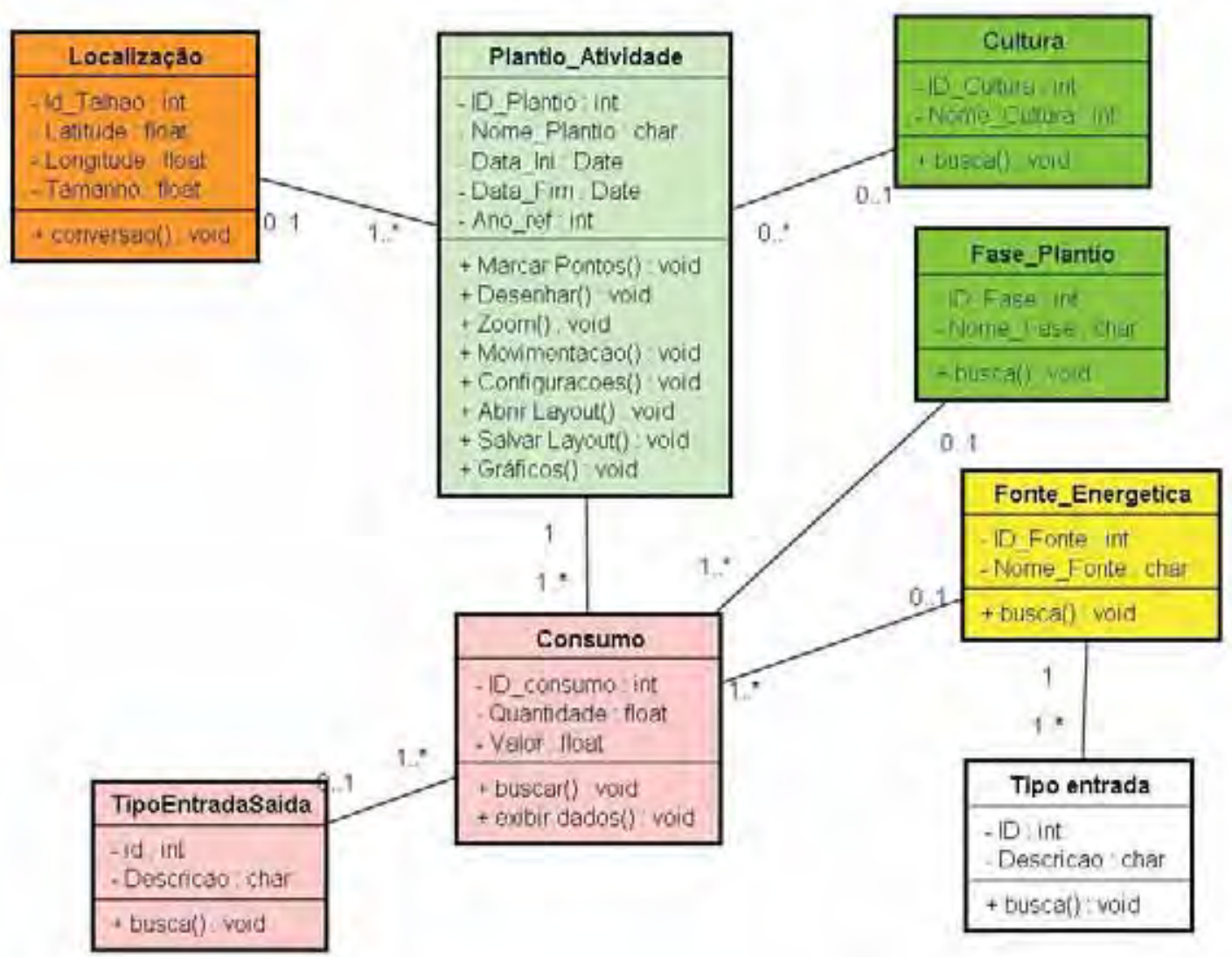

Figura 18: Diagrama de Classes do Servidor 


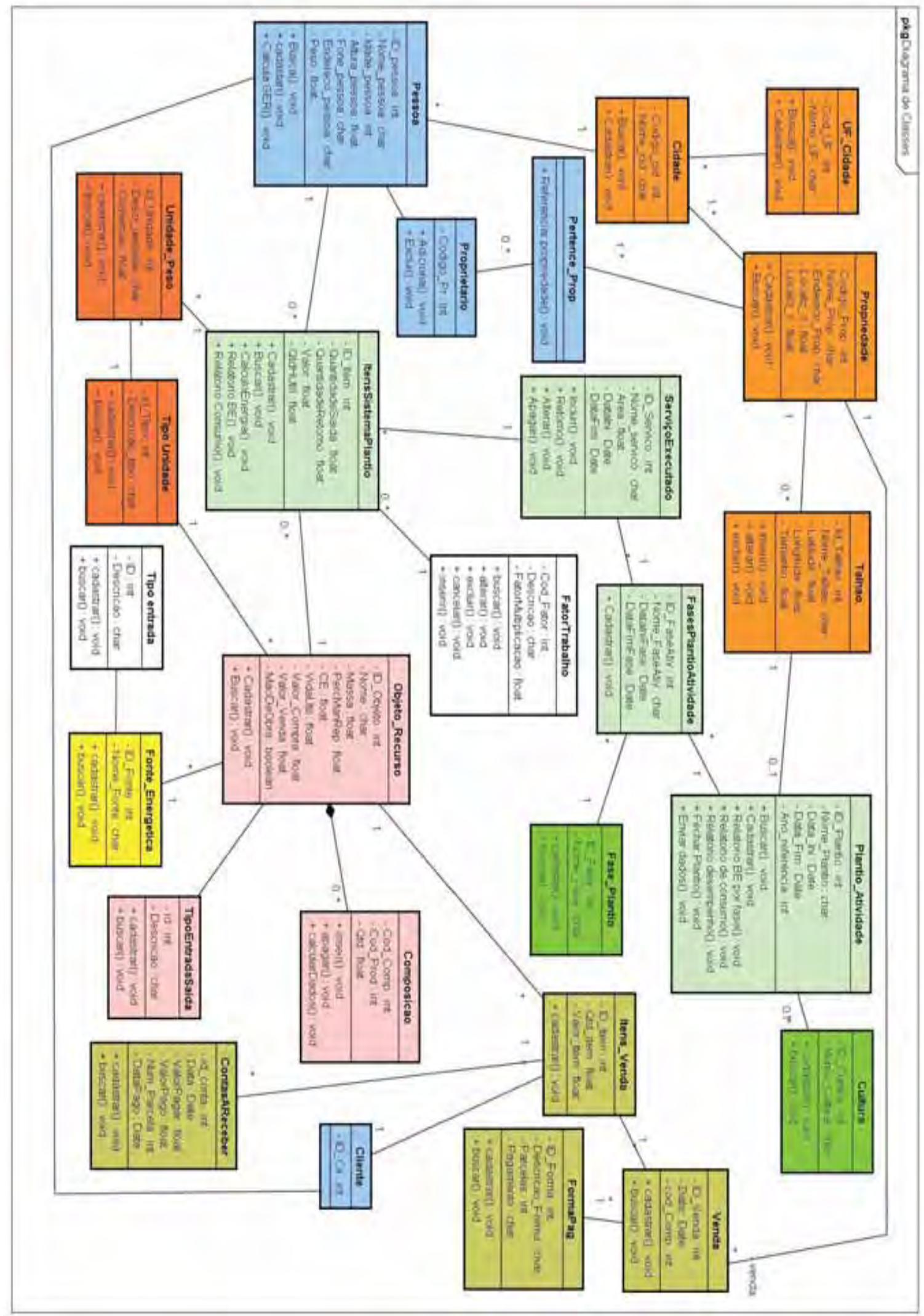

Figura 19: Diagrama de Classes do software cliente 


\subsection{DISCUSSÃO}

O Sistema desenvolvido possui funções que contemplam as necessidades básicas de uma propriedade rural.

O Sistema foi testado em uma das propriedades rurais, tendo em vista que os proprietários deveriam adquirir um equipamento computacional para terem acesso ao software. Os requisitos de Hardware mostraram-se baixos, e com uma configuração bem modesta já é possível executar o sistema.

Todas as telas de cadastro seguem um modelo básico, composto por uma tela inicial com a possibilidade de executar buscas por diversos campos (Figura 20) e Filtros (Figura 21).

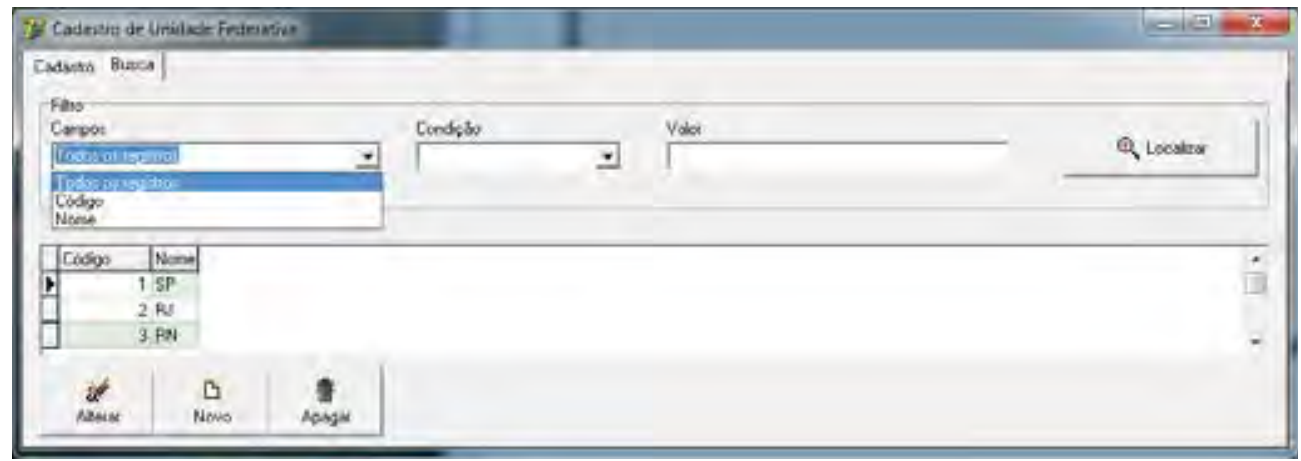

Figura 20: Cadastro padrão - Campo que será executado a busca 


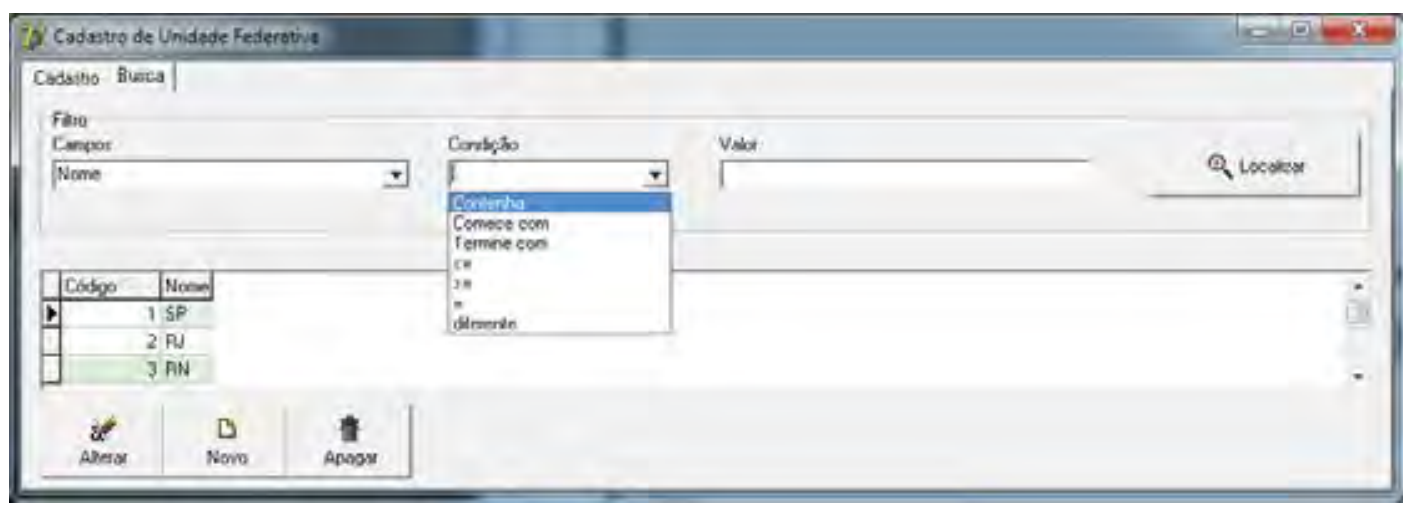

Figura 21: Cadastro padrão - Critérios de busca

Quando um registro for encontrado, o mesmo poderá ser editado. Se não for localizado o registro, o usuário poderá incluir um novo (Figura 22).

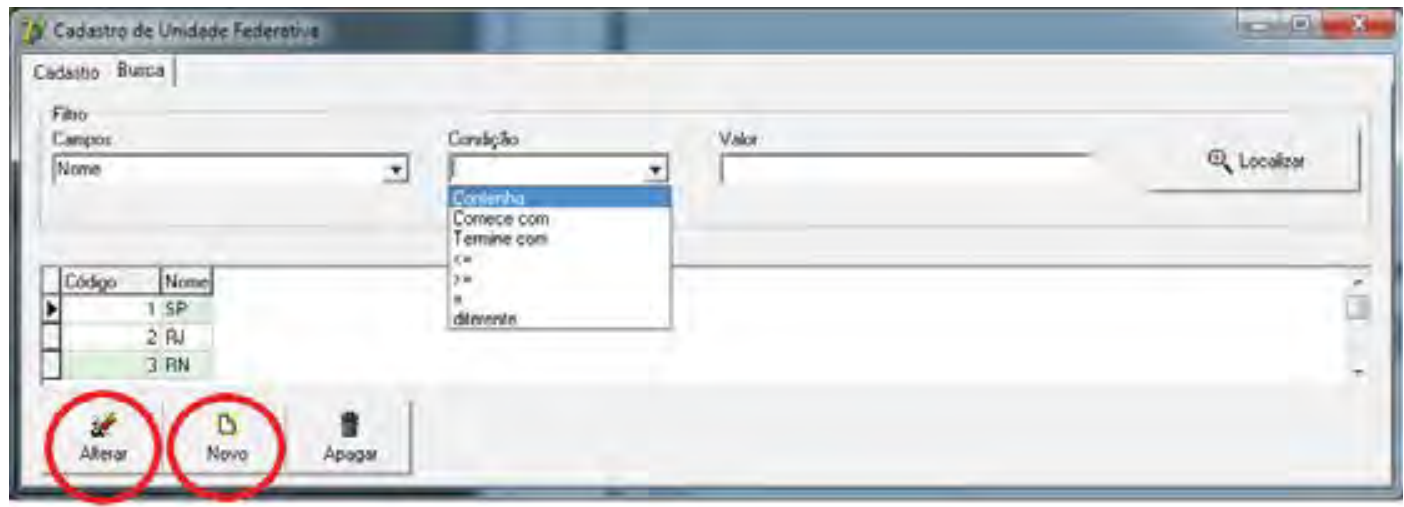

Figura 22: Inserir ou alterar um registro

O processo de uso do sistema é descrito a seguir:

Ao executar o sistema, é apresentado o menu principal do sistema, com as principais funcionalidades (Figura 23). 


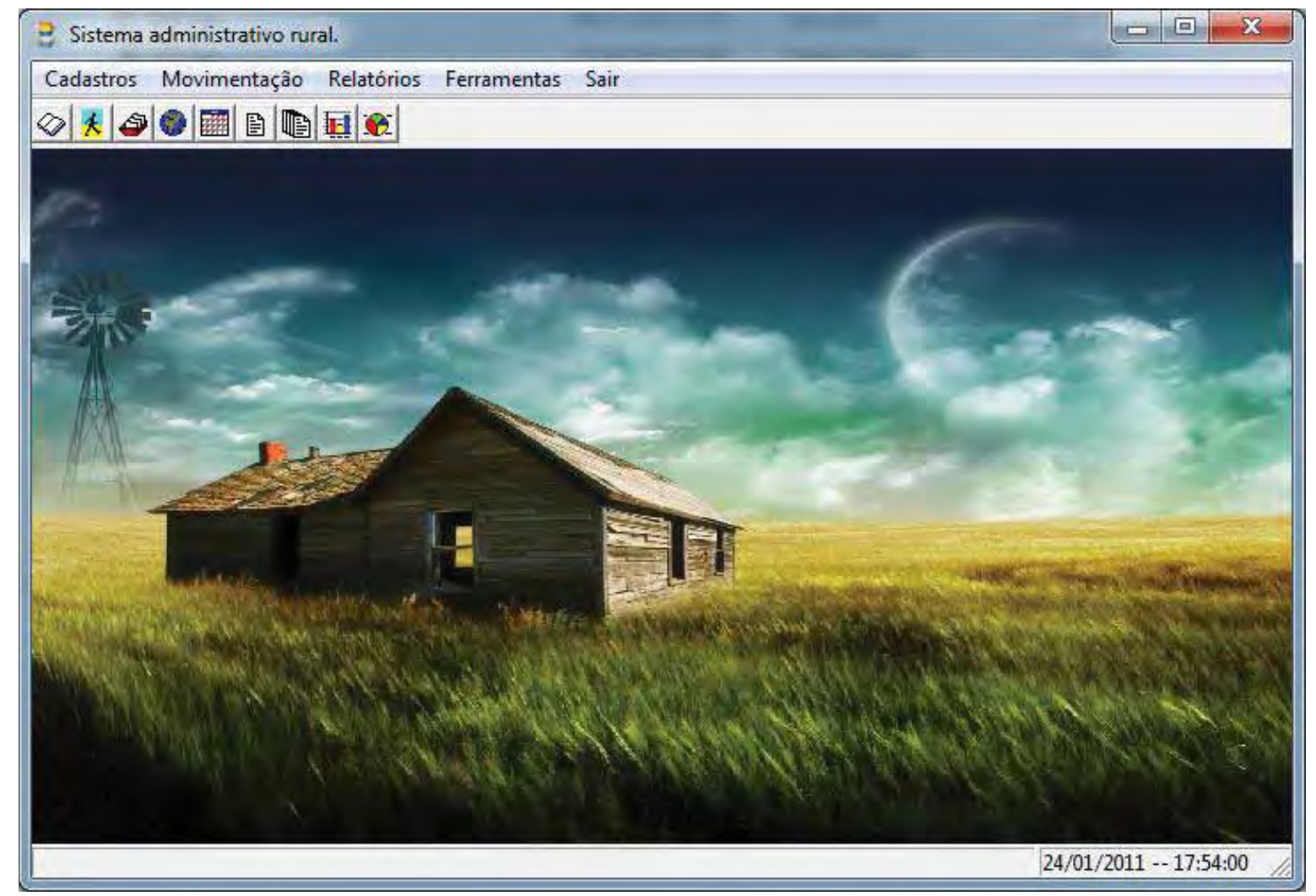

Figura 23: Menu principal do Sistema

No menu de Cadastro, estão disponibilizados os cadastros básicos para o funcionamento dos sistema. Um cadastro muito importante é o cadastro de propriedade (Figura 24), no qual o usuário deverá cadastrar a localização (GIS) (Figura 25) e cadastrar os talhões culturais, isto é, uma propriedade poderá ser dividida em uma ou mais áreas de cultura, com características diferenciadas. Por exemplo, uma propriedade rural poderá ser dividida em dois talhões, um com o plantio de cana de açúcar e outro com uma cultura e café (Figura 26). 


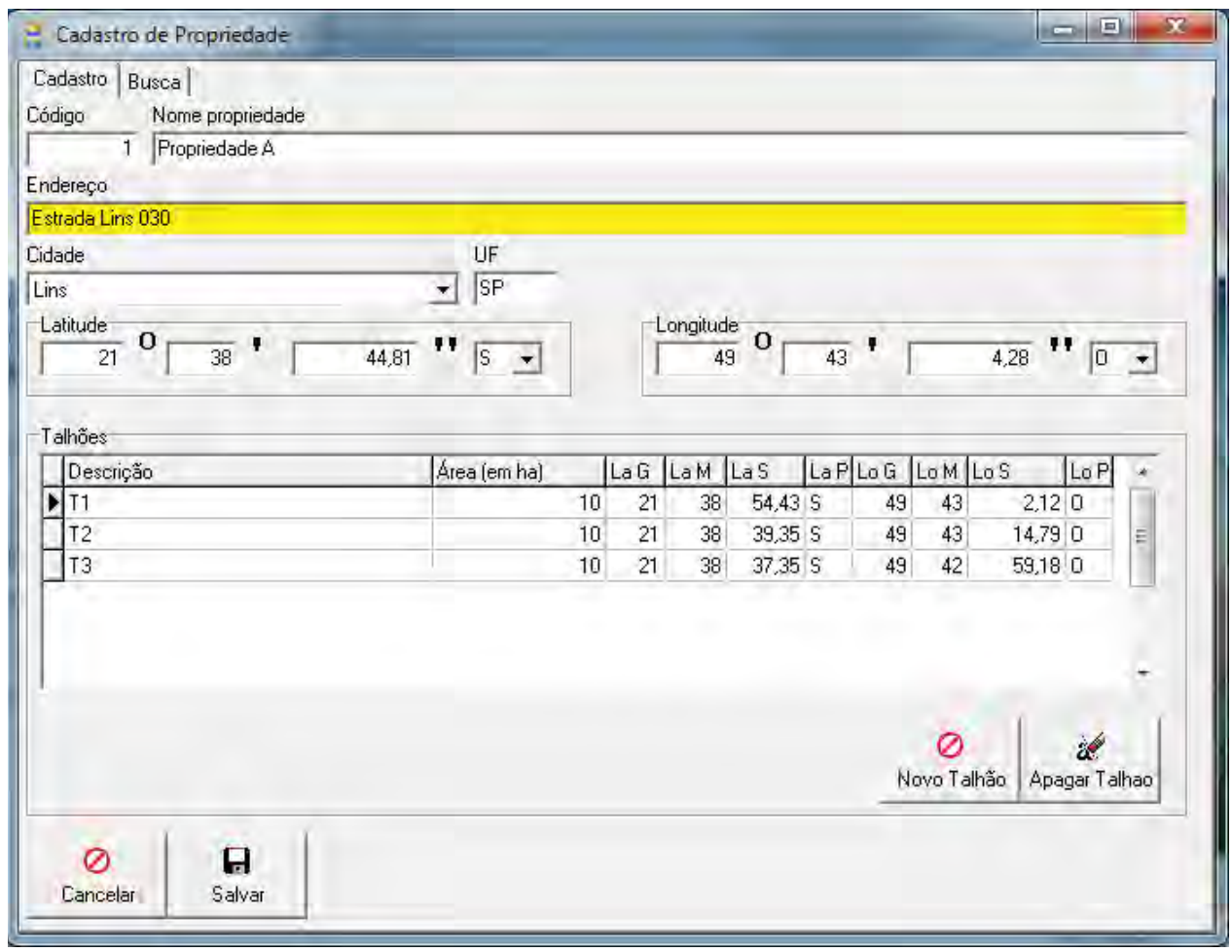

Figura 24: Cadastro de Propriedades

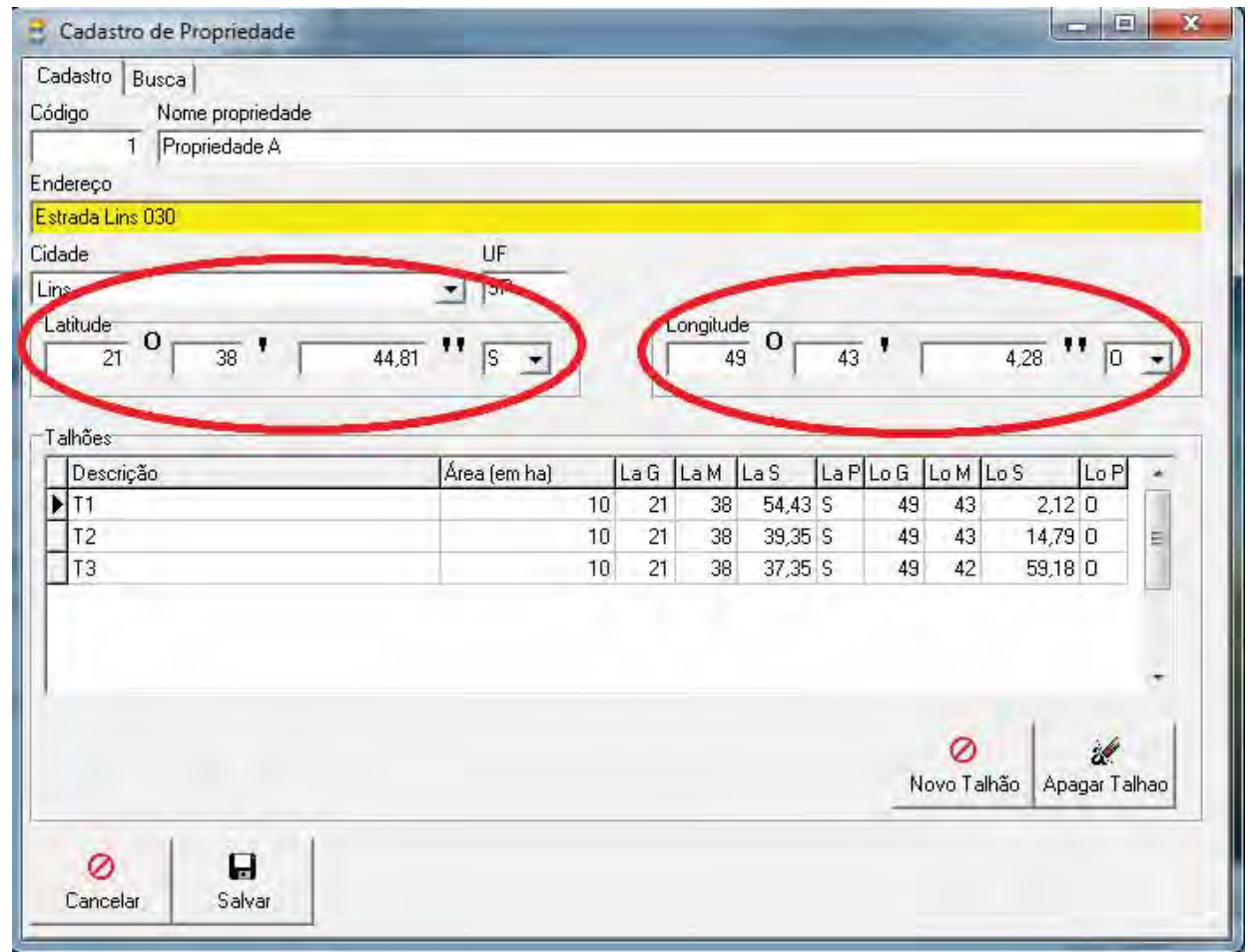

Figura 25: Coordenadas GIS 
No caso específico do talhão (Figura 26), é necessário informar a latitude e a longitude do mesmo (coordenadas que podem ser obtidas com o auxilio de um GPS). Assim, com estes dados, os gráficos podem ser desenhados com mais exatidão ao gerar o mapa do consumo energético brasileiro.

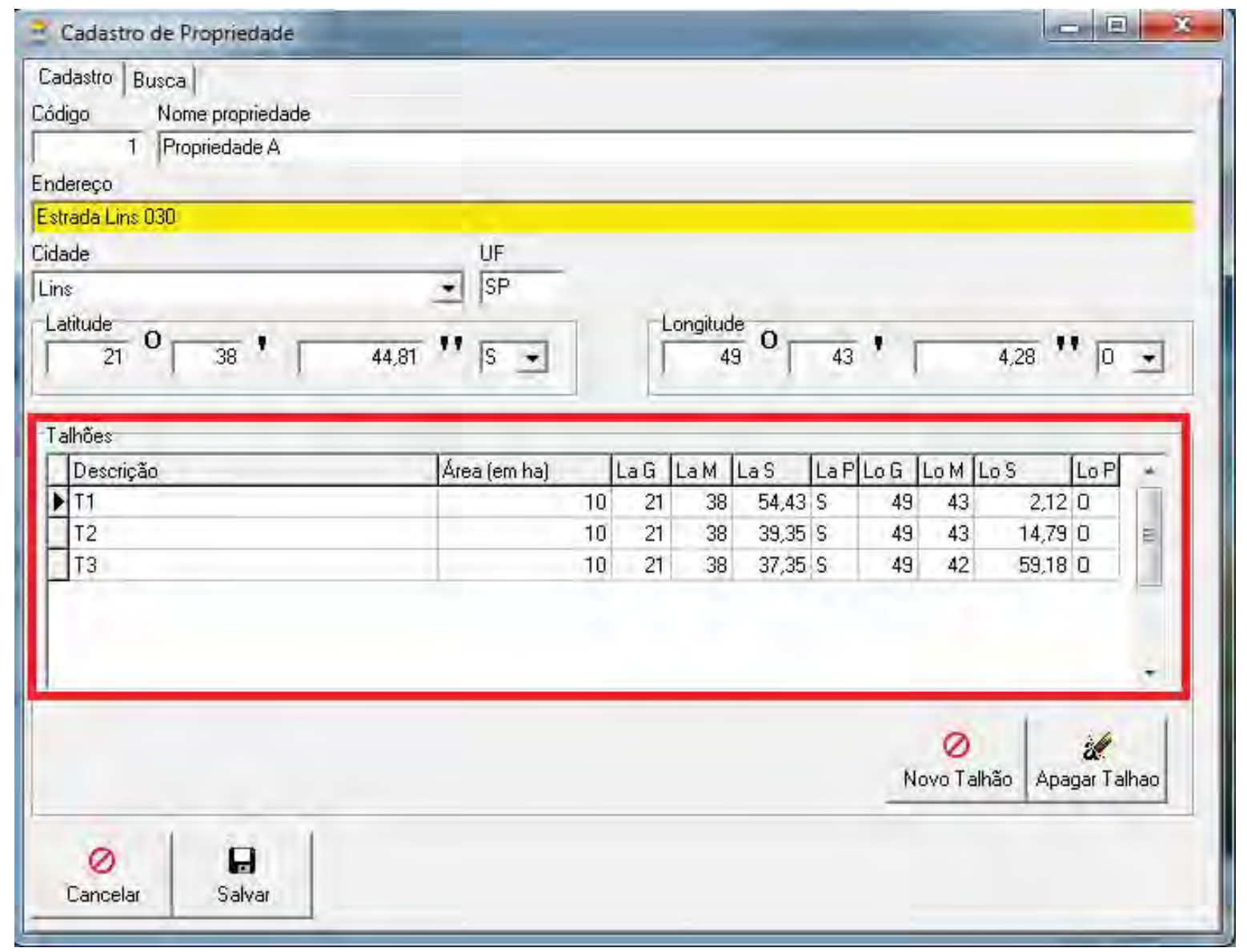

Figura 26: Cadastro de Talhões

No caso do inicio de uma nova cultura (Figura 27), como por exemplo, o plantio de tomate de verão, é necessário definir o local de plantio (talhão) e qual a cultura será iniciada no local. 


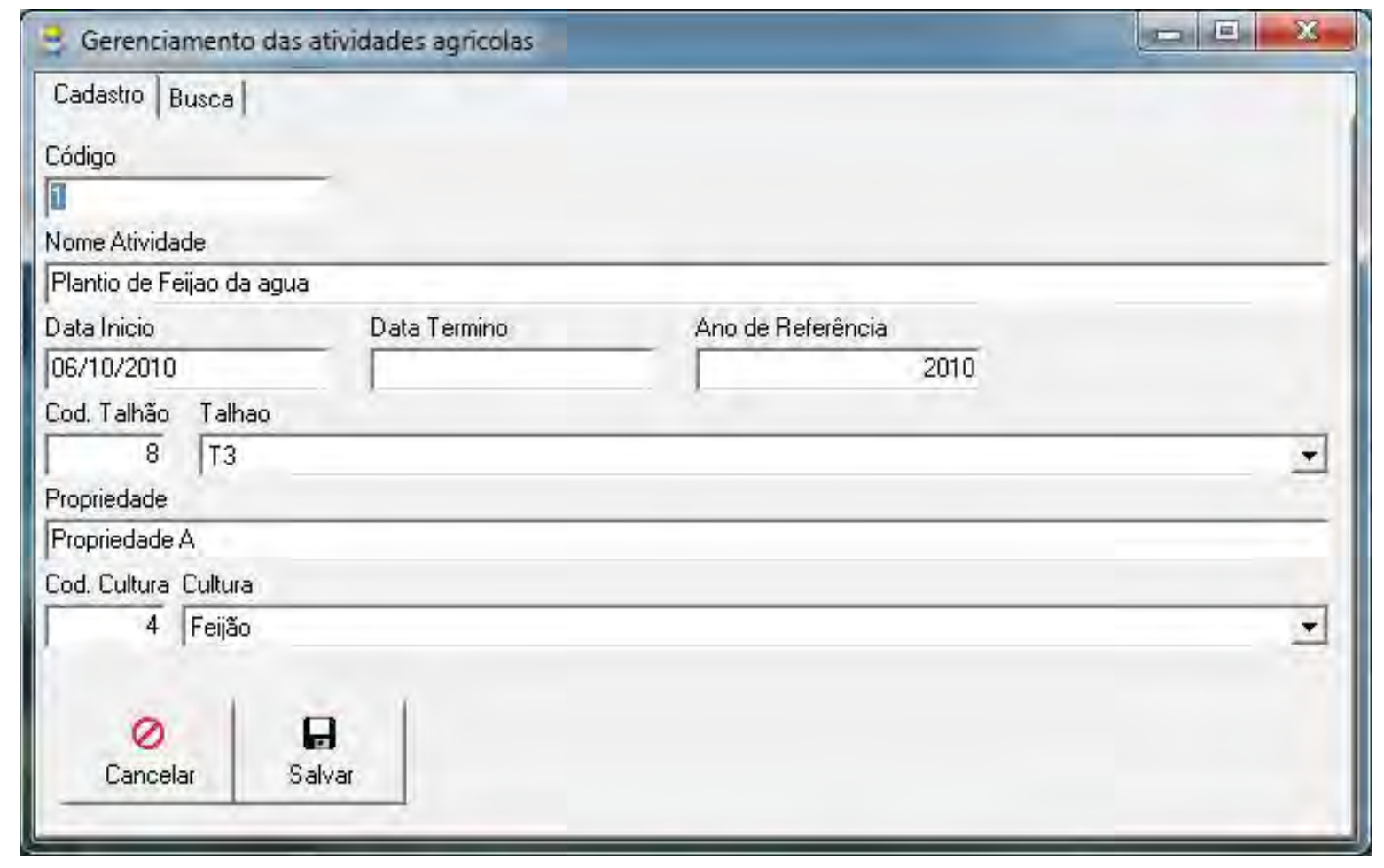

Figura 27: Gerenciamento das atividades agrícolas

Outro cadastro muito importante é o de recursos (Figura 28). Basicamente, um recurso é um objeto utilizado no cultivo de uma cultura. Um recurso pode ser de entrada, saída ou ambos. Todas as atividades executadas em uma cultura necessitam de um recurso, como por exemplo, um trator, insumos, sementes, horas de mão de obra, etc. A grande maioria dos objetos são objetos compostos por uma única fonte energética (por exemplo, o óleo diesel, de origem fóssil) (Figura 29). 


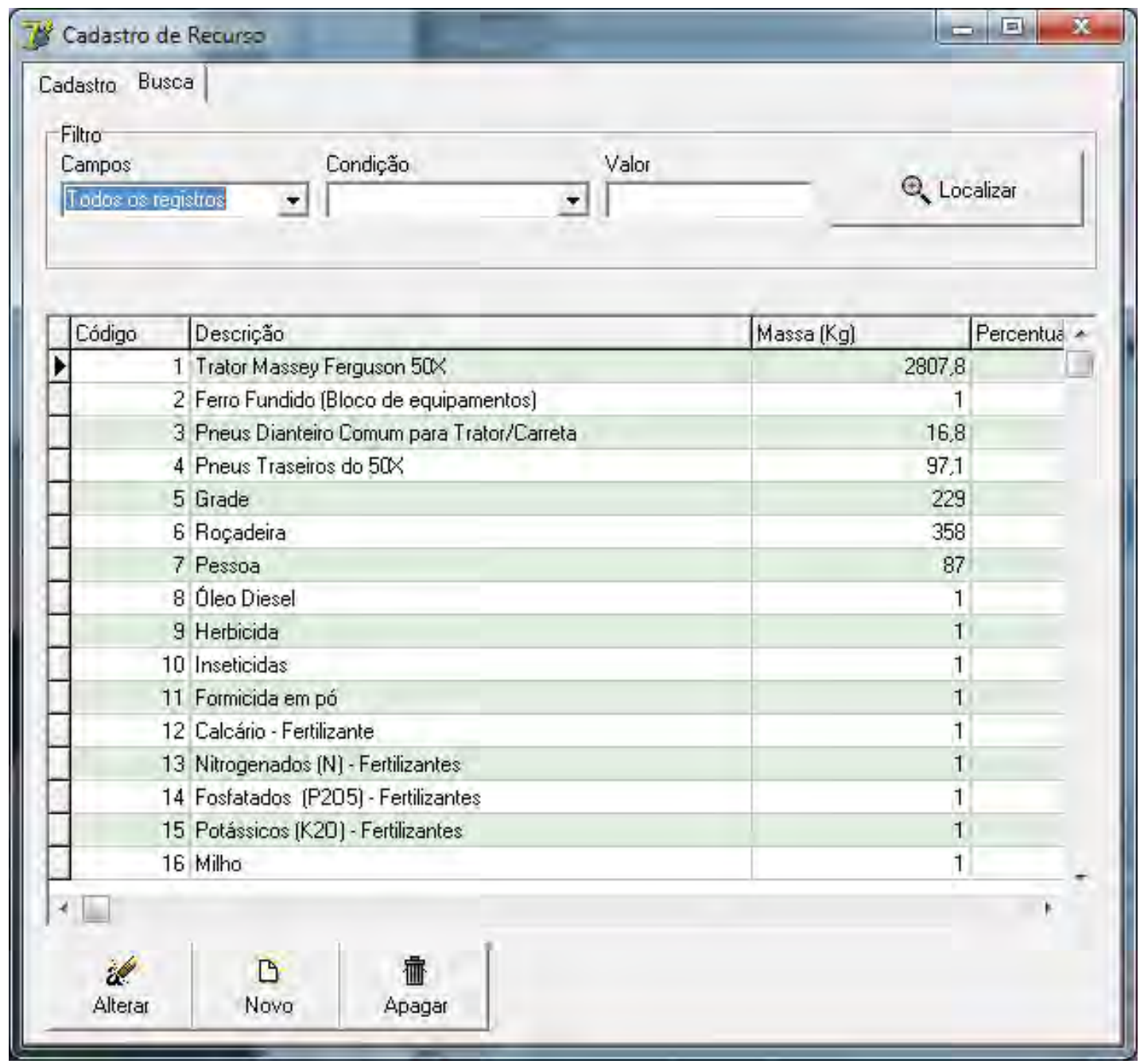

Figura 28: Cadastro de Recurso 


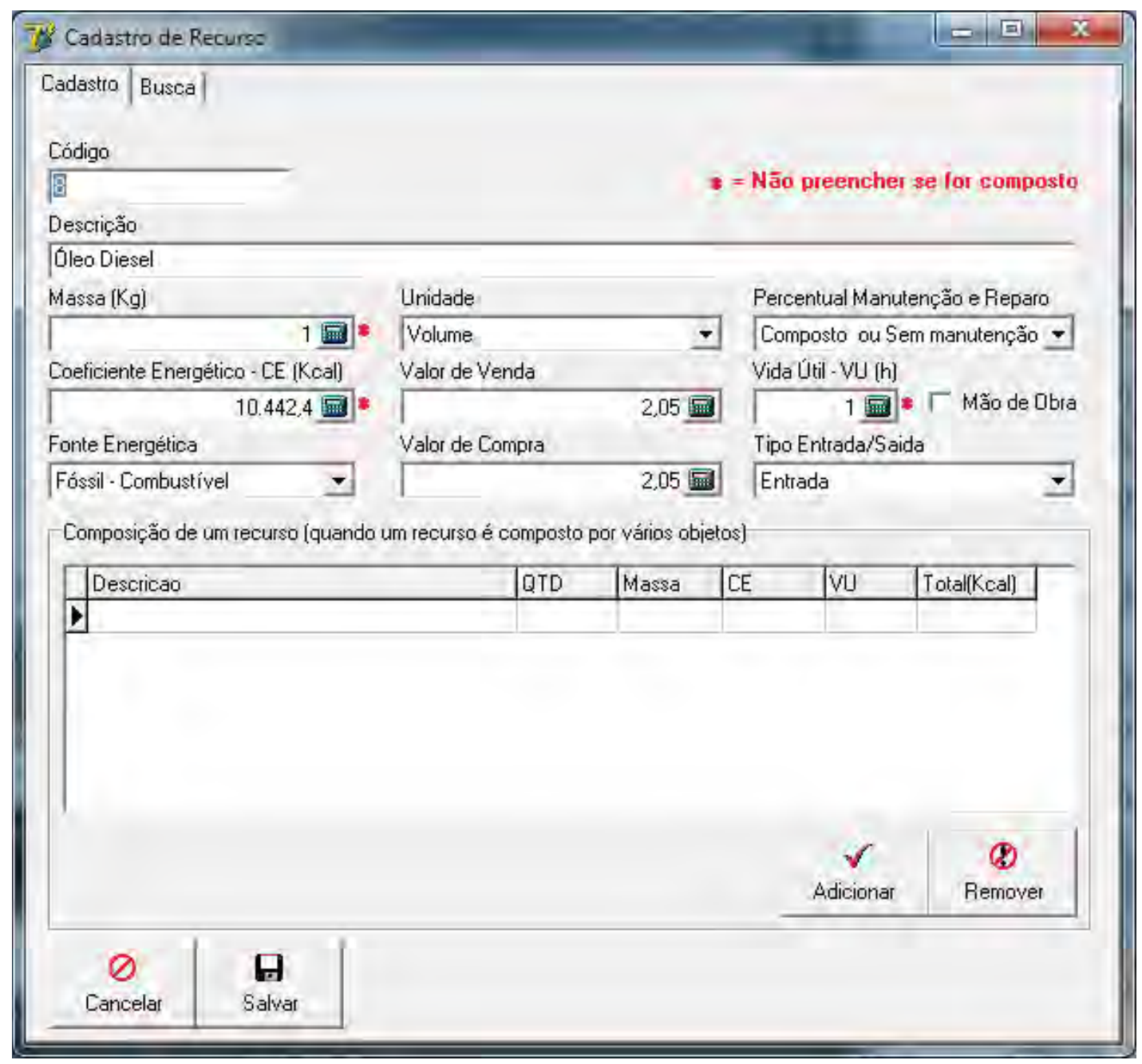

Figura 29: Cadastro de recursos - Objeto padrão

Alguns recursos não seguem este padrão, por serem formados por mais de um tipo de fonte energética. Assim, este recurso é composto por dois ou mais recursos, que podem ter diferentes fontes energéticas (Figura 30). Neste caso, o sistema calcula os dados de massa total e coeficiente energético automaticamente, de acordo com os recursos que foram adicionados. A vida útil será o maior valor apresentado entre os objetos da composição. Um exemplo deste caso é o trator, pois o mesmo possui uma estrutura em ferro industrializado e um conjunto de pneus de origem fóssil. 


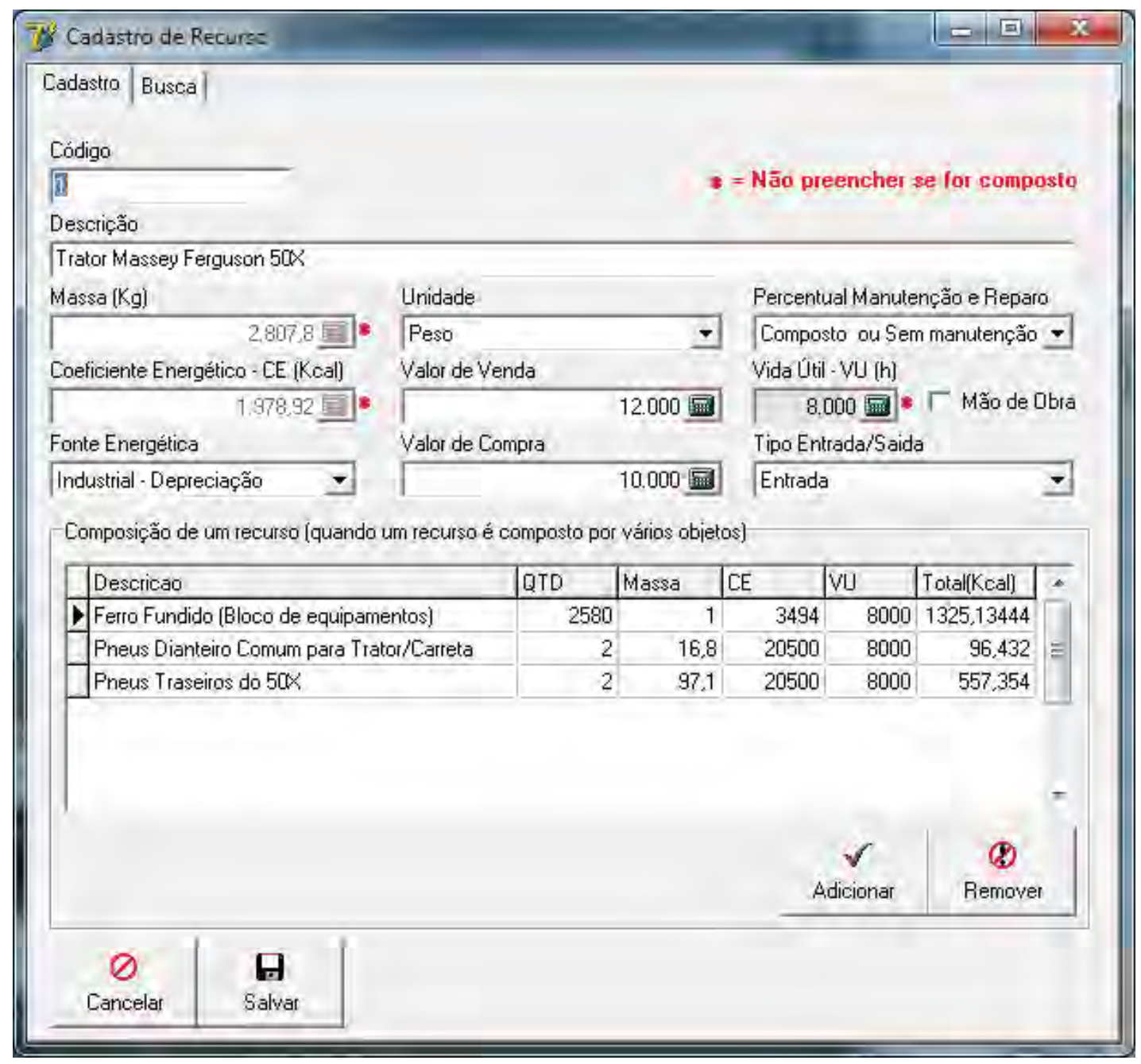

Figura 30: Recurso composto.

Após esta etapa, inicia-se a etapa de movimentação de recursos dentro de um sistema de plantio. A principal atividade é gerenciar o uso dos recursos energéticos utilizados em uma cultura (Figura 31). Se uma atividade de plantio já foi finalizada, não será possível alterar os lançamentos já realizados e tão pouco inserir novos. 


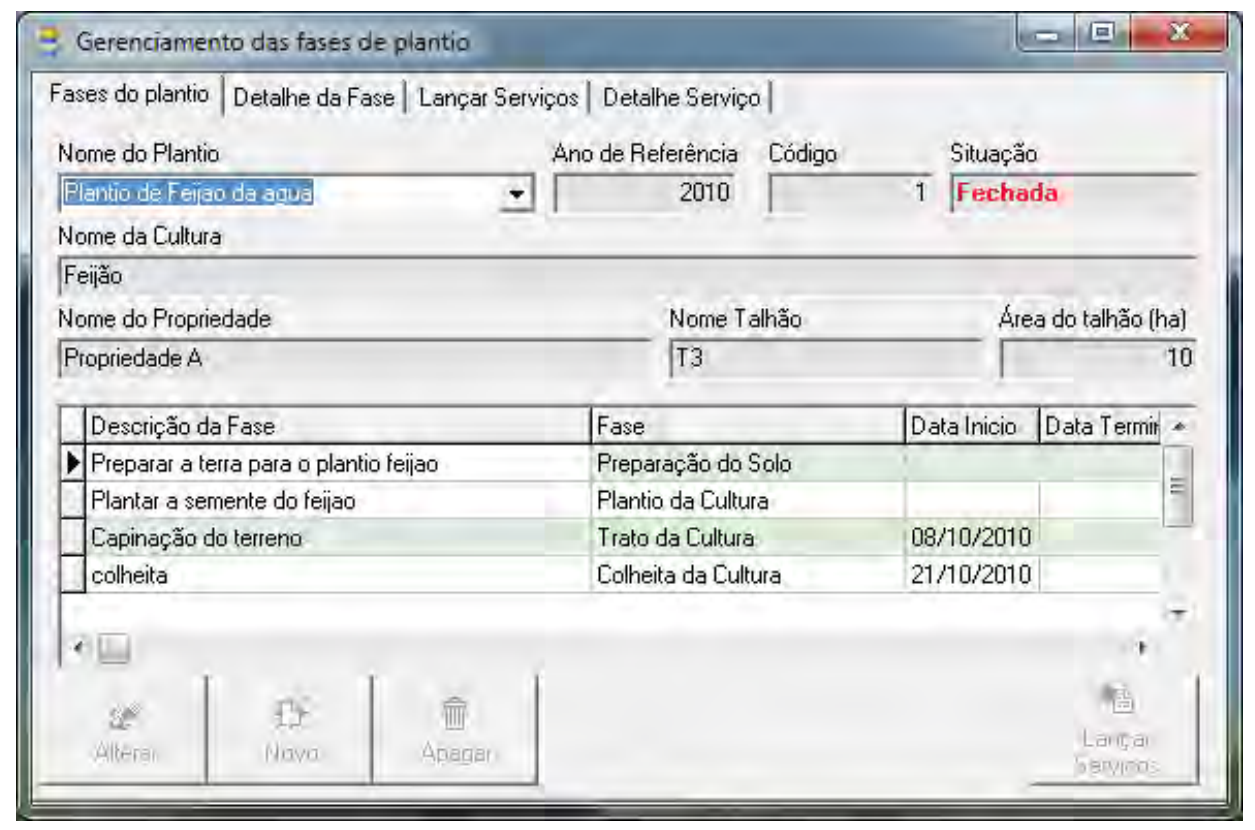

Figura 31: Gerenciar as fases do plantio - Fechada

Quando o usuário escolhe uma cultura que ainda não teve as suas atividades finalizadas, é possível lançar novos eventos (Figura 32 ).

Basicamente, um evento é uma atividade cultura a ser realizada em uma determinado talhão.

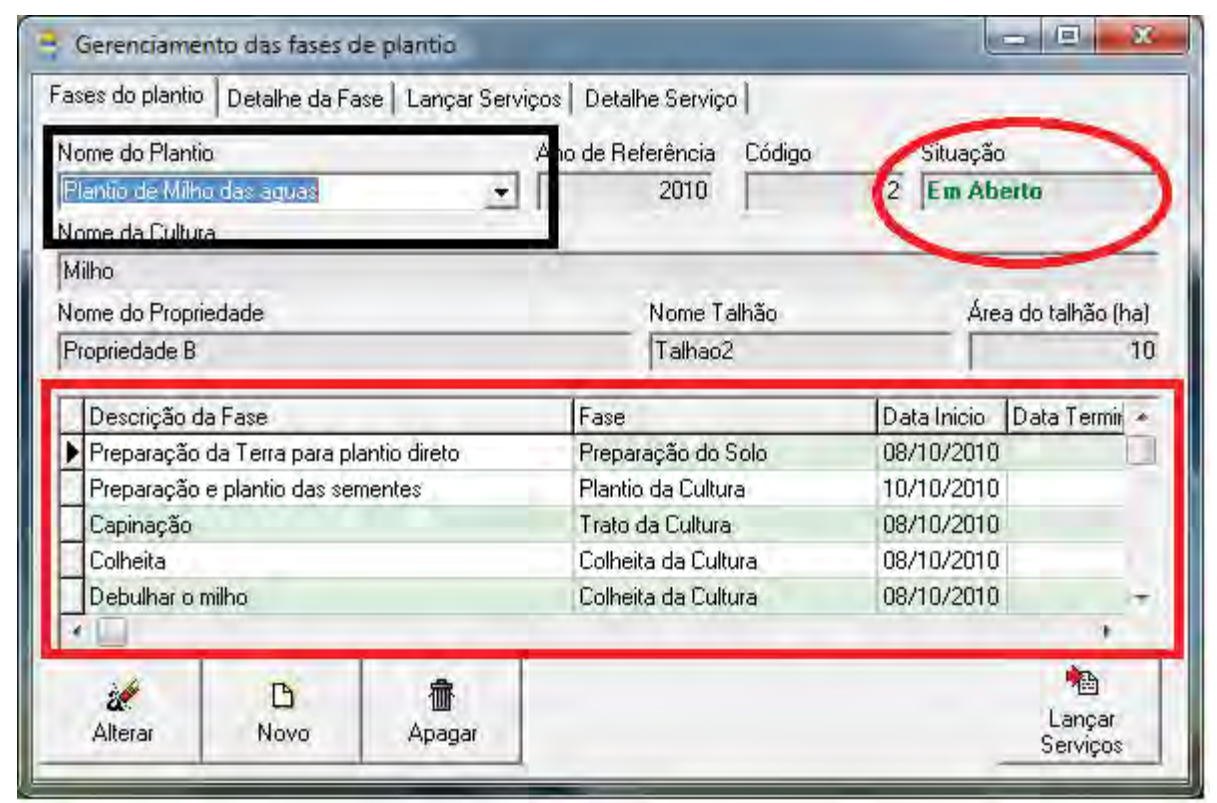

Figura 32: Fase do plantio aberta 


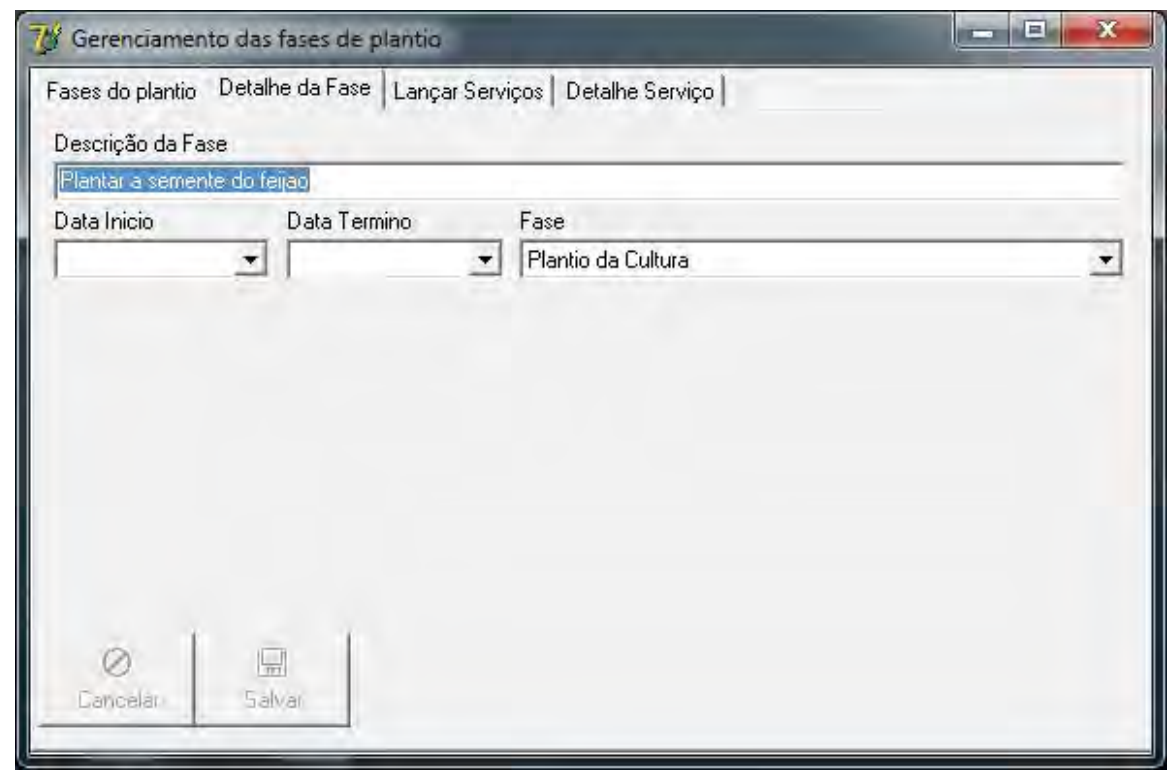

Figura 33: Detalhamento da fase de plantio

Com as fases da cultura lançada, é necessário definir os serviços que serão executados em cada fase e os recursos necessários (Figura 34).

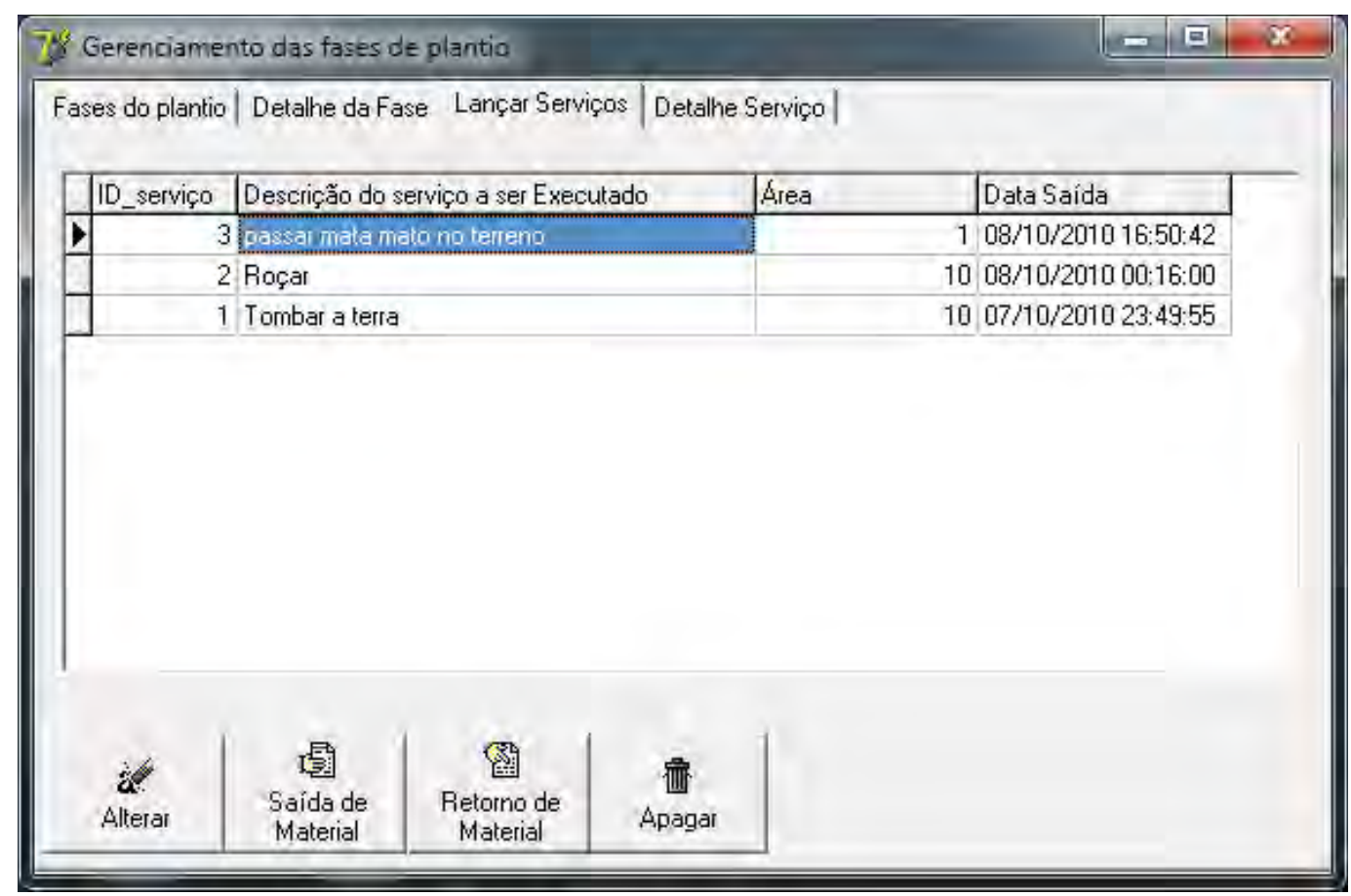

Figura 34: Lançamento de Serviços 
Neste caso, existem quatro possibilidades:

- Alterar um serviço já cadastrado

- Cadastrar um novo serviço e os objetos necessários (saída de materiais)

- Lançar o retorno de materiais não utilizados durante um serviço - sobras (Retorno de material).

- Remover um serviço que não será executado.

Quando a opção escolhida for lançar uma saída de material, o usuário poderá cadastrar os recursos que irá necessitar para executar o serviço (Figura 35).

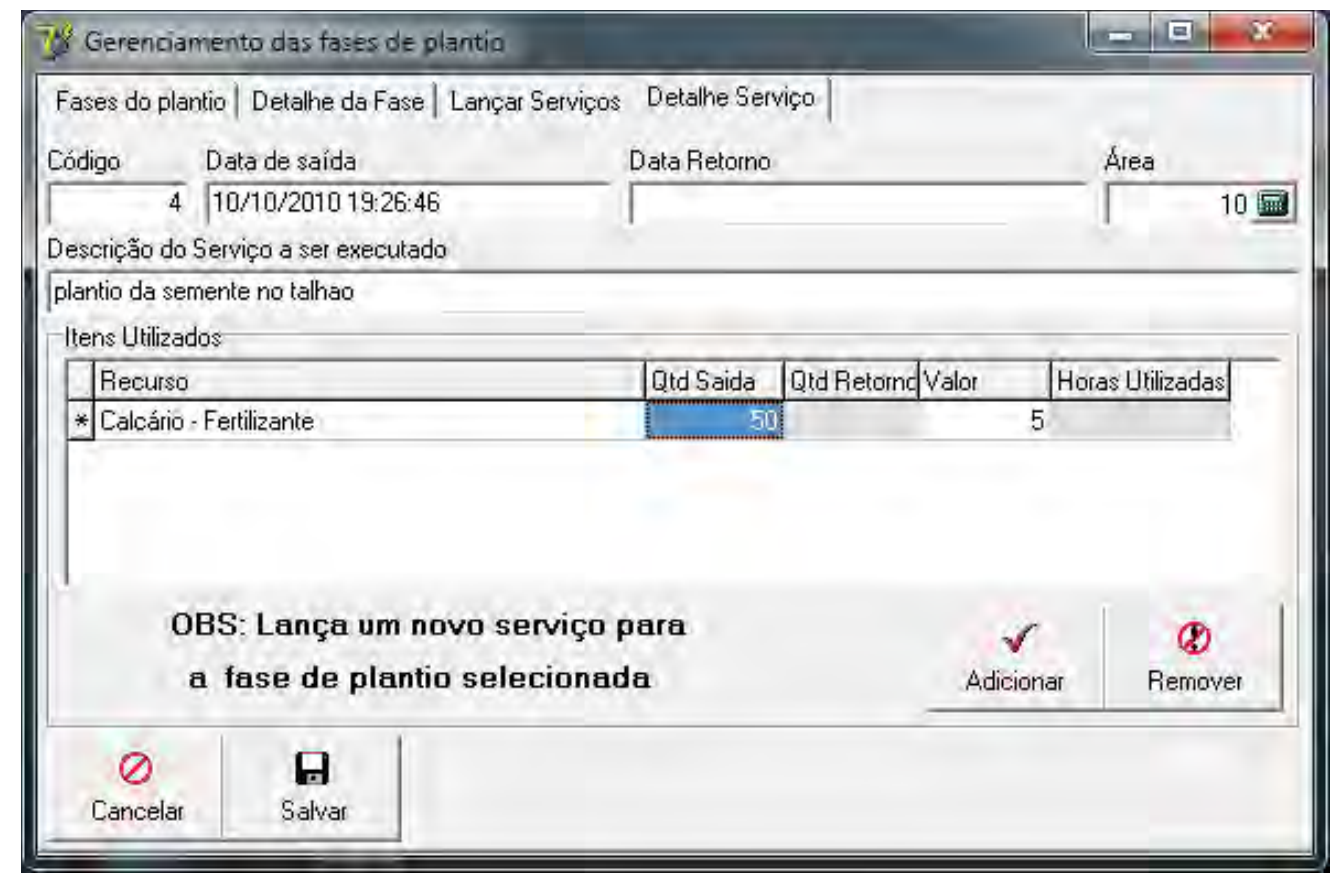

Figura 35: Lançar recursos para um serviço

No caso específico de mão de obra, é necessário calcular o GER. Neste caso, é necessário as informações de peso, altura e idade do individuo. O Sistema então irá requisitar as informações a respeito do usuário e do tipo de trabalho que será realizado (Figura 36). 


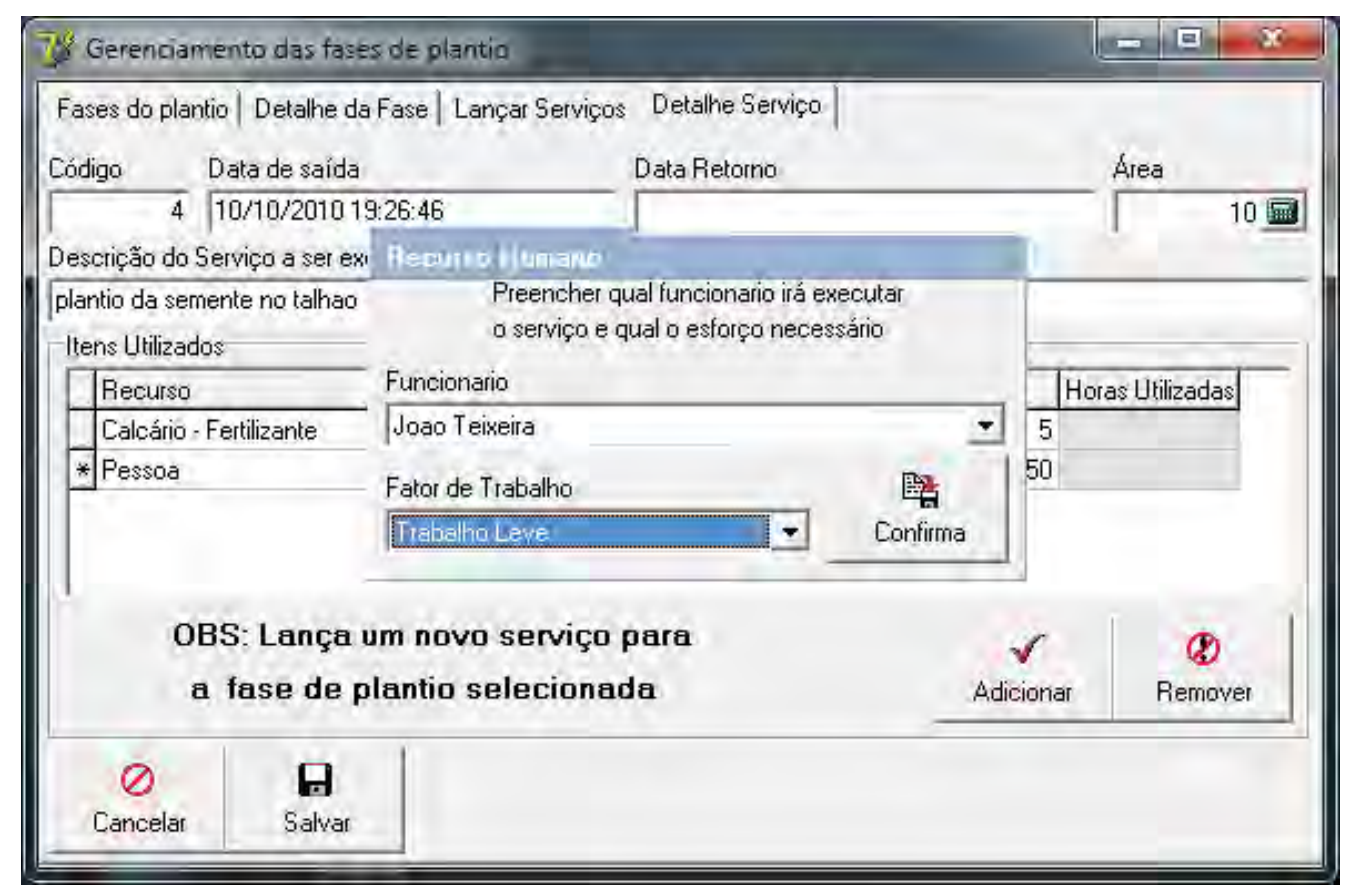

Figura 36: Recurso Biológico - Pessoa

O fator de trabalho é previamente cadastrado no sistema (Figura 37). Este fator é utilizado nos cálculos de gasto energético humano. A escala é uma adaptação do trabalho de Seixas(1991) (Figura 37).

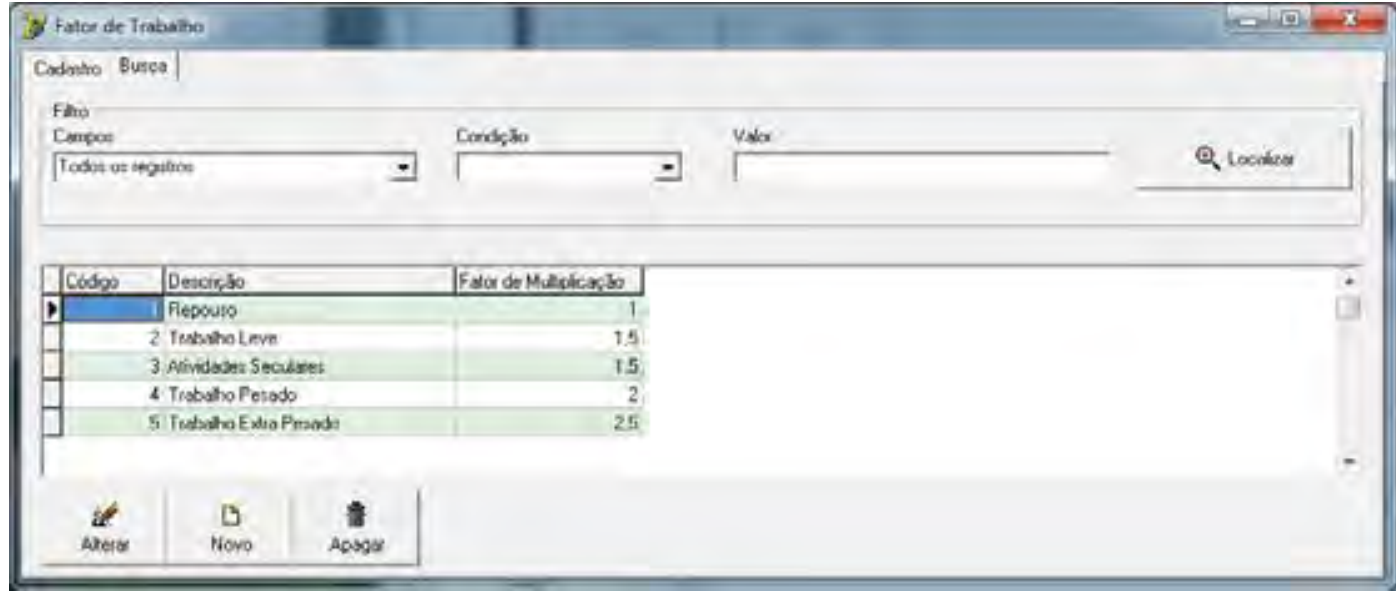

Figura 37: Fator de trabalho 
Cada recurso tem, obrigatoriamente, uma fonte energética (Fóssil, industrial, biológica, etc)(Figura 38).

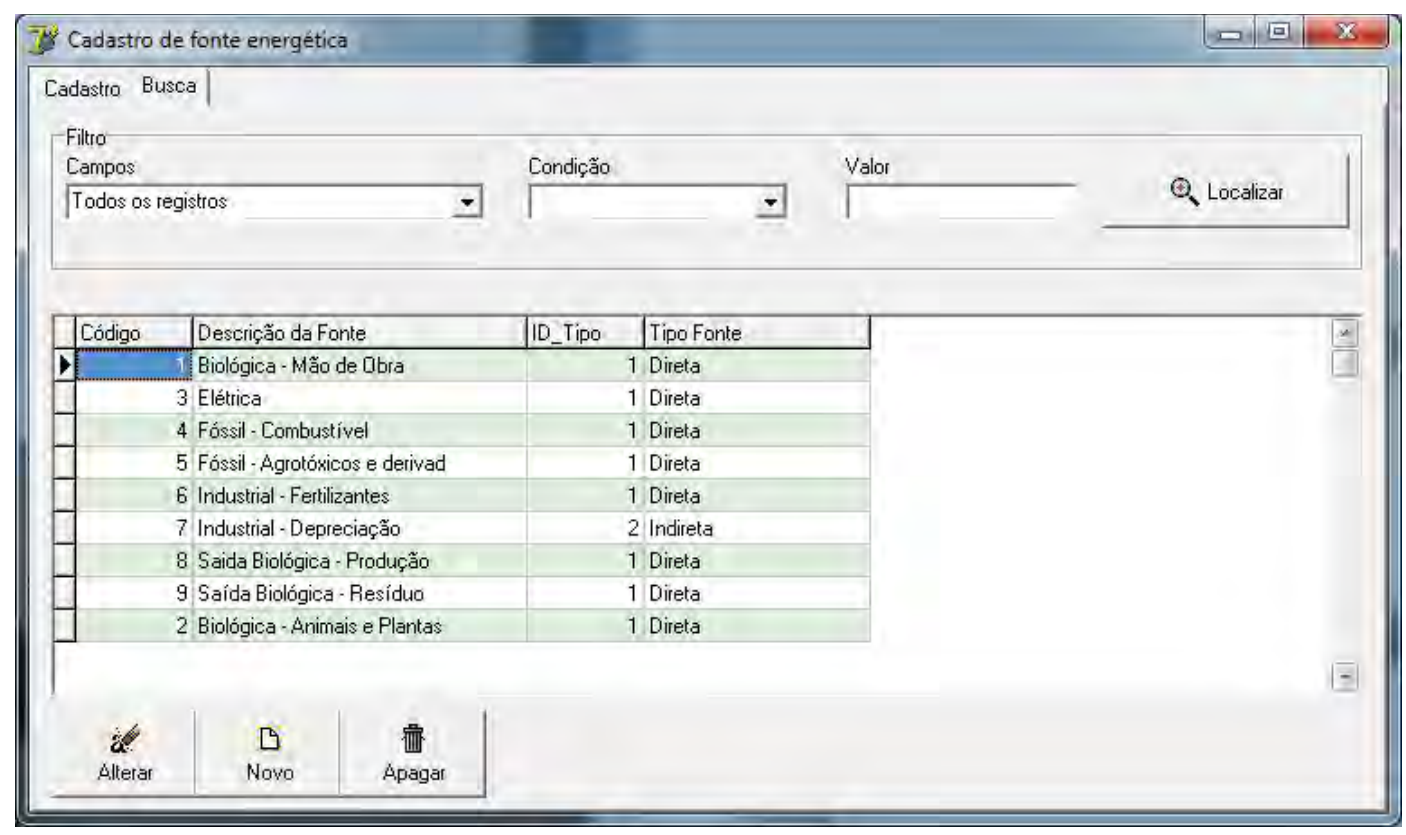

Figura 38: Cadastro de fonte energética

Durante os cálculos, é necessário informar quem irá executar uma operação (pessoa que irá executar a tarefa). Como os cálculos dependem de alguns dados (como por exemplo a altura e o peso), é necessário cadastrar as pessoas que irão interagir com a cultura: Proprietário (Figura 39) e Trabalhadores (Figura 40). 


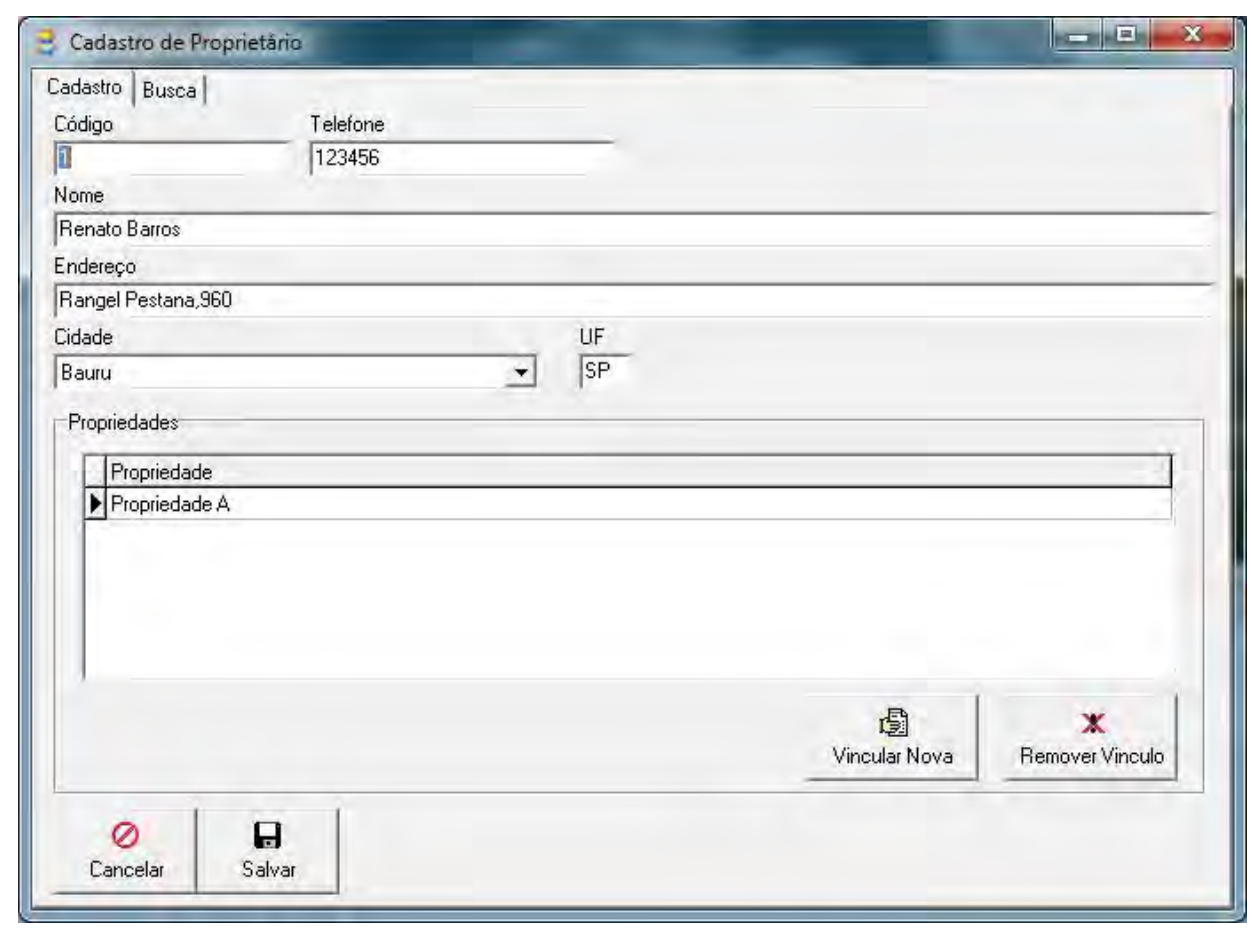

Figura 39: Cadastro de proprietários

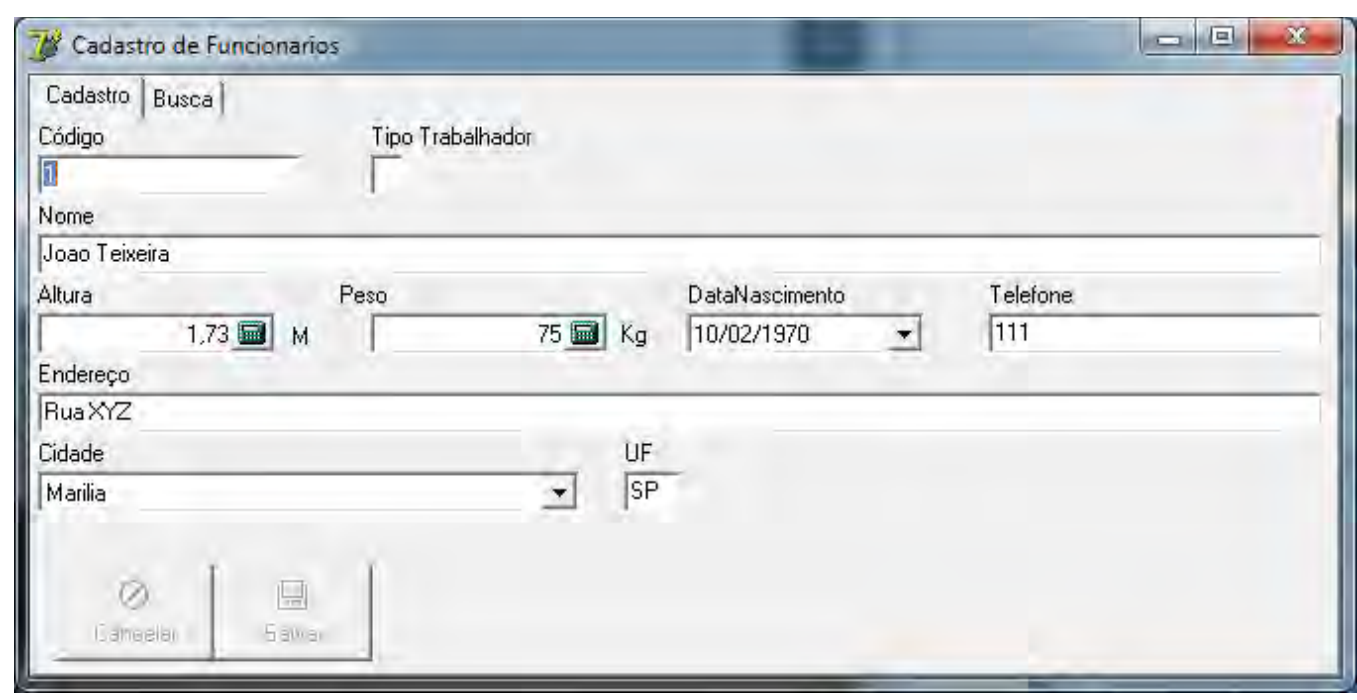

Figura 40: Cadastro de Pessoas

No caso do retorno de materiais, o sistema calcula automaticamente o tempo total utilizado. Caso o valor não corresponda à realidade, o usuário deverá entrar com os valores corretos (Figura 41). 


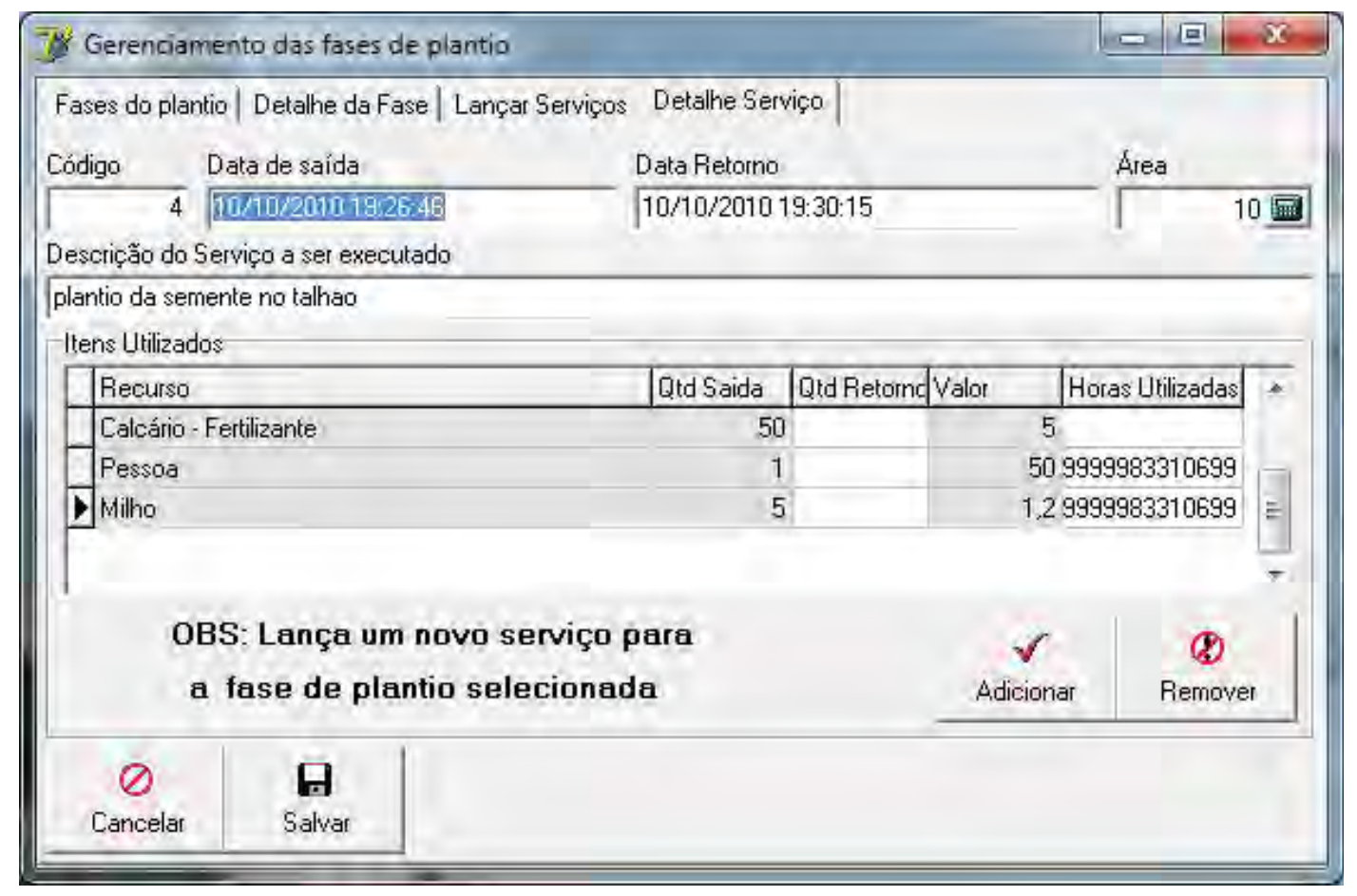

Figura 41: Retorno de materiais do campo

Após o fechamento de uma safra, o produtor poderá gerar os relatórios gerencias e energéticos (Figura 42 a 47): 


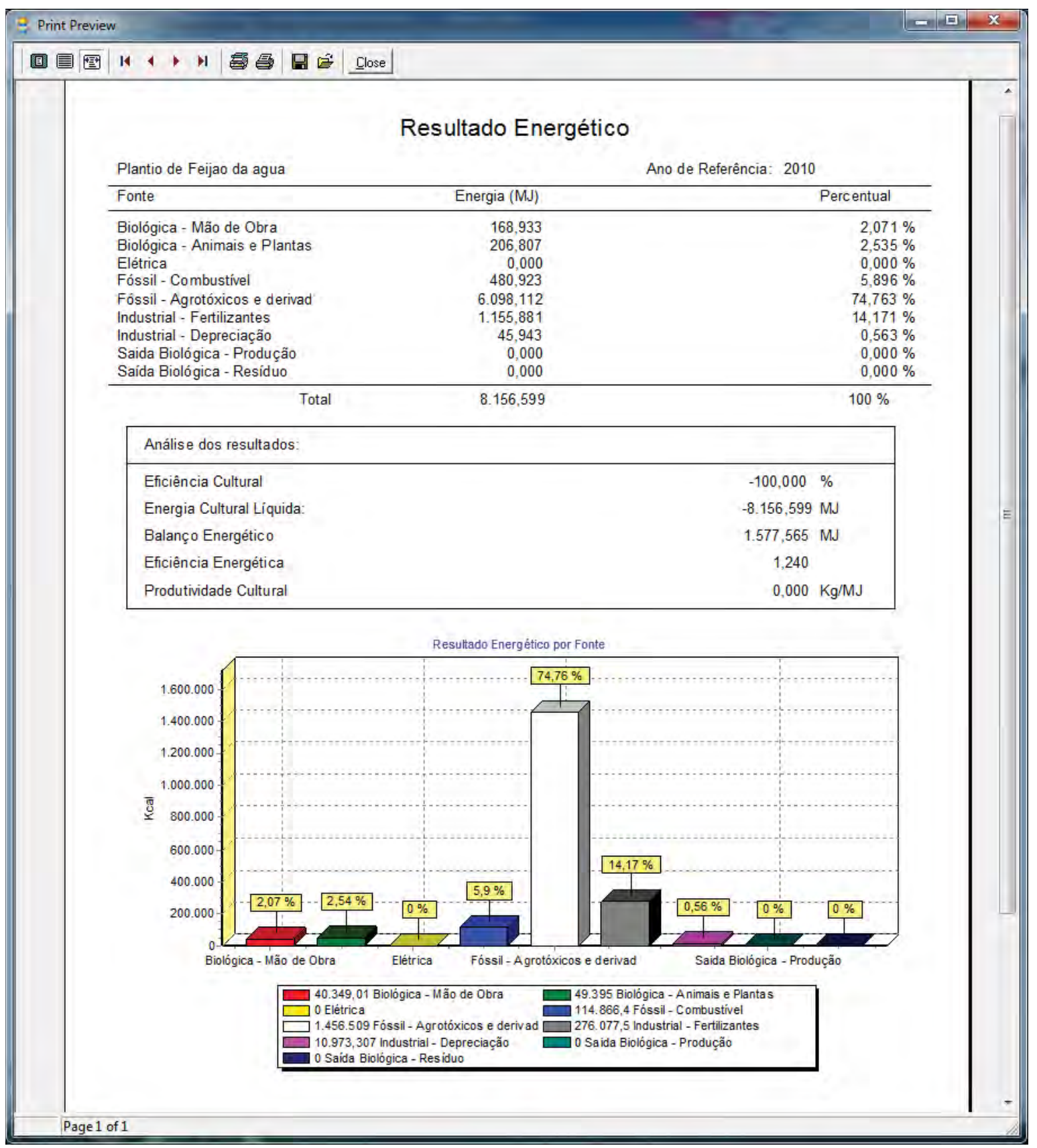

Figura 42: Balanço energético 


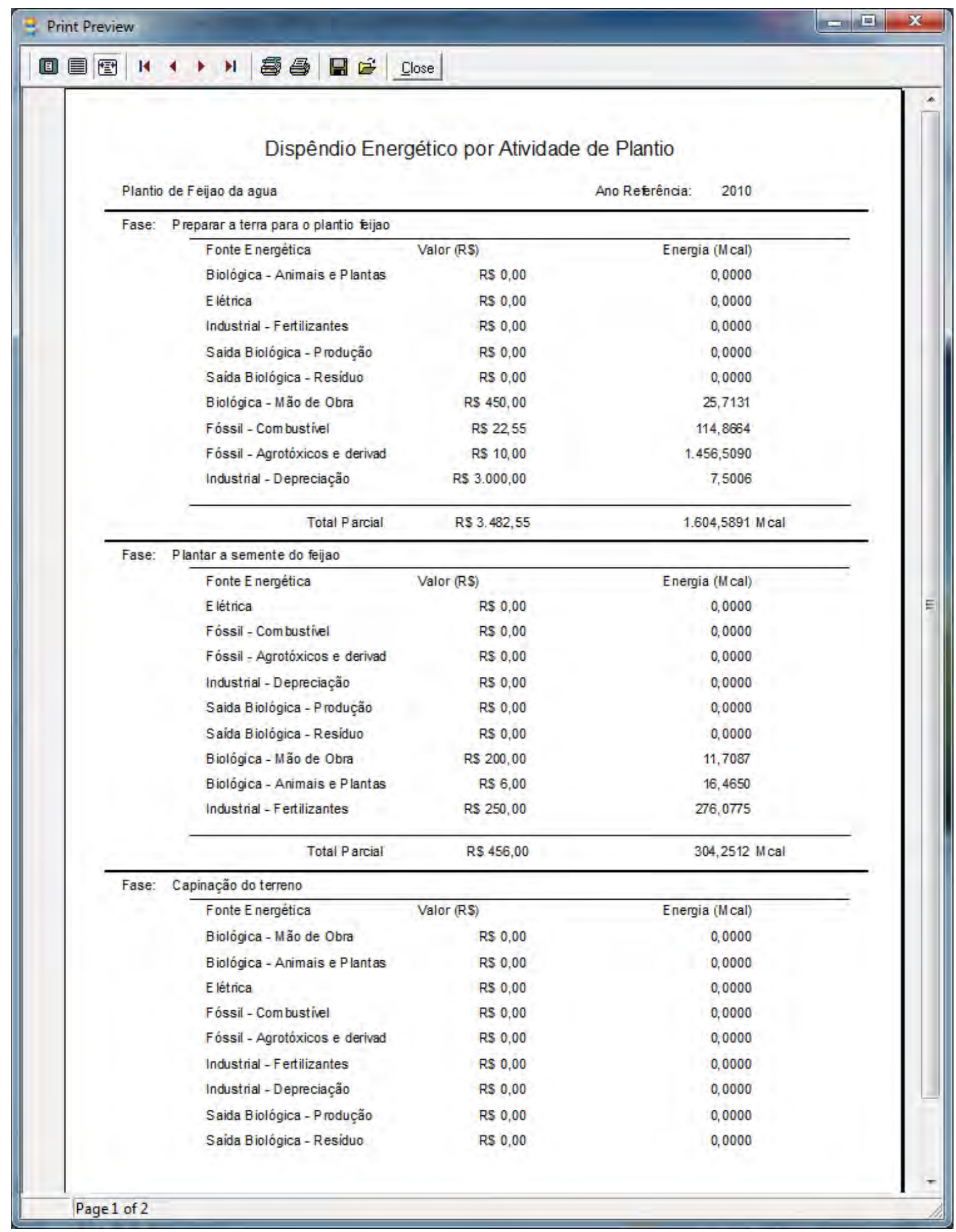

Figura 43: Dispêndio energético por atividade de plantio. 


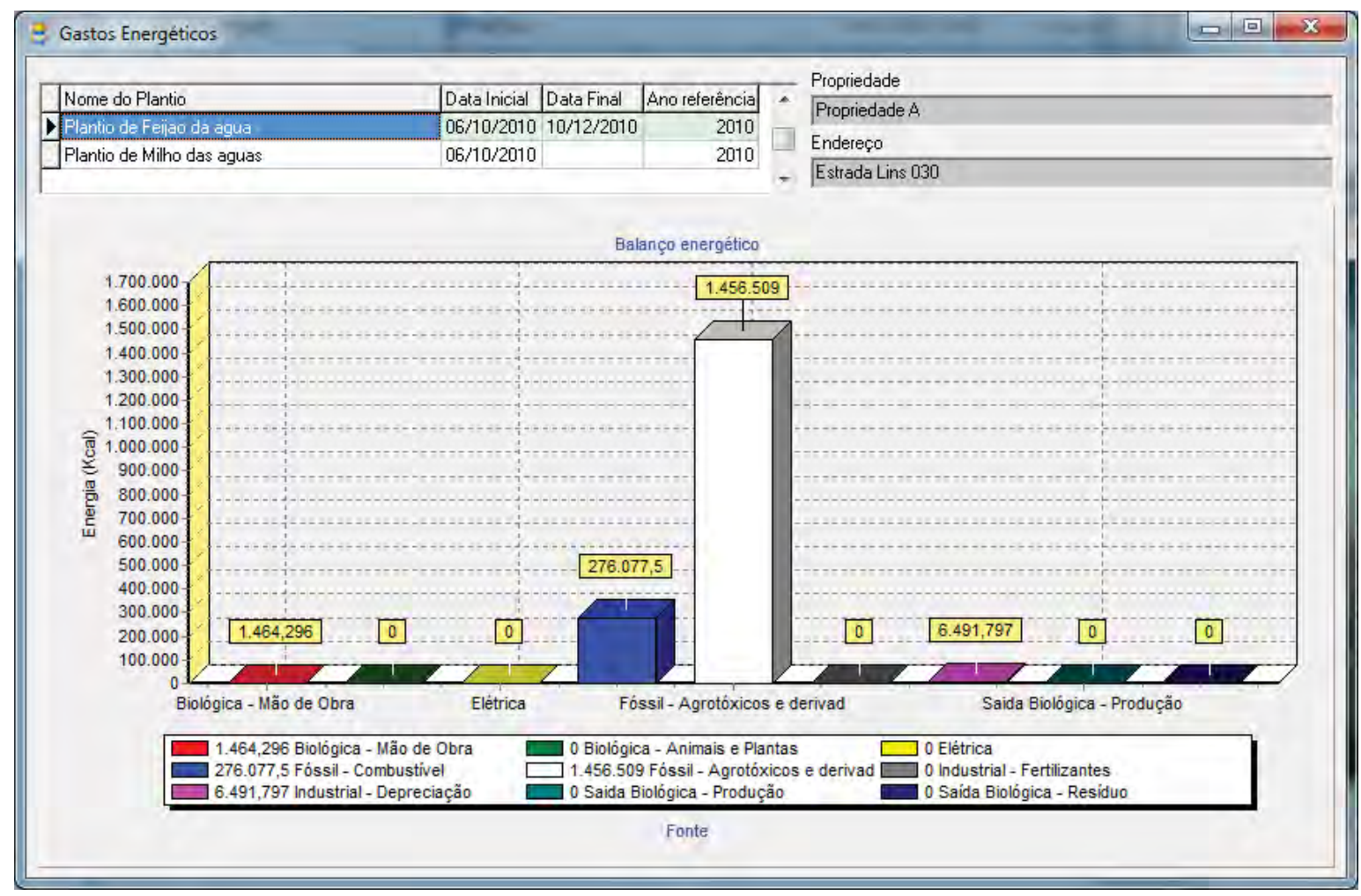

Figura 44: Analise de gastos energéticos por cultura

Ficará a cargo do produtor o envio dos dados para uma base centralizada. Estes dados poderão ser enviados via Internet ou através de copia em disco para ser entregue em um posto de coleta conveniado.

Os dados enviados para o servidor irão compor uma base de dados consolidada, permitindo levantar o perfil energético de uma região. O servidor roda em formato desktop (acesso local dos dados armazenados), mas nada impediria do mesmo ser desenvolvido para a plataforma web, liberando assim o sistema para consultas externas.

A tela principal do servidor é composta por um software de georreferenciamento, capaz de mostrar as coordenadas informadas pelos produtores rurais e seus respectivos valores (Figura 45). 


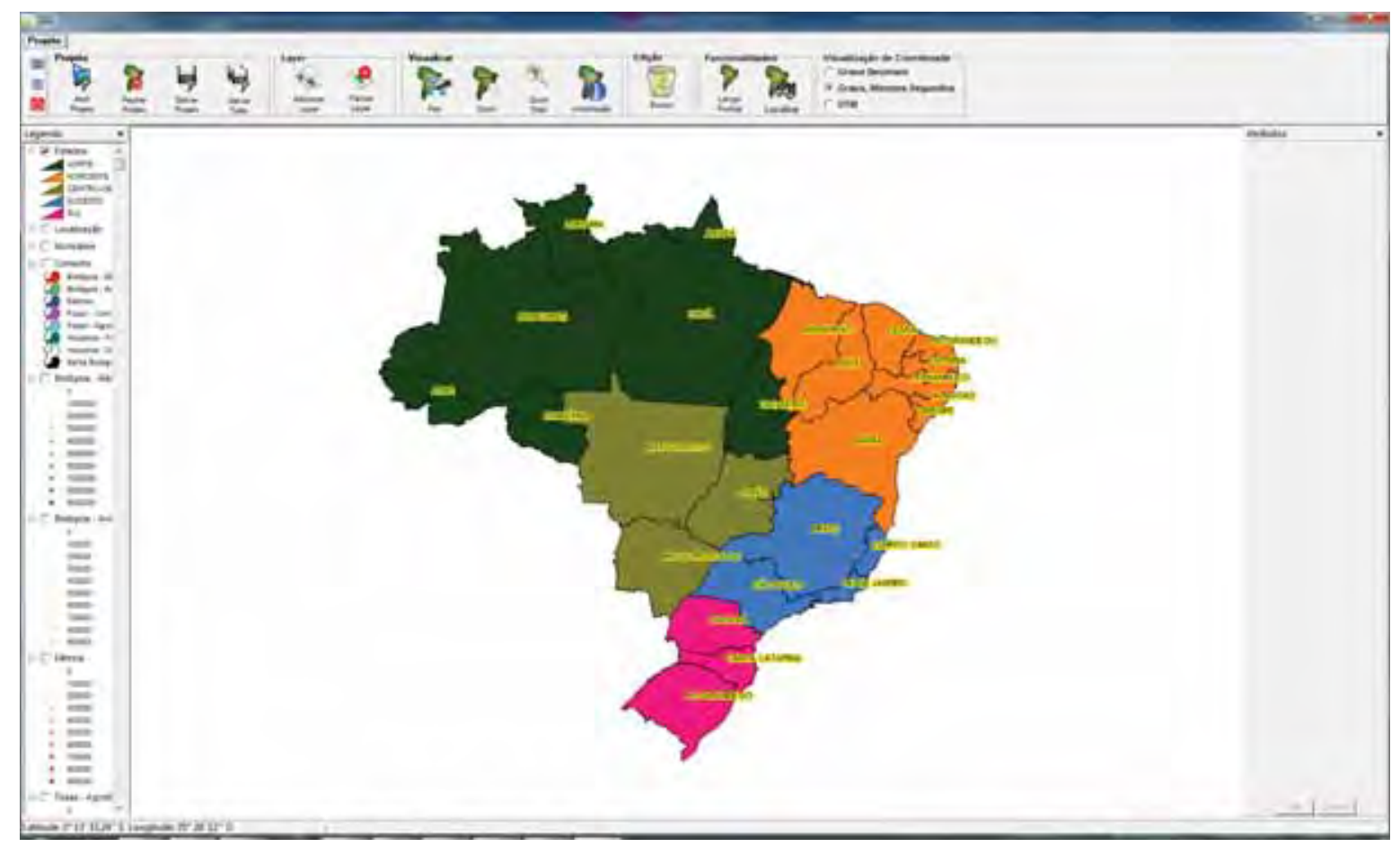

Figura 45: Tela principal do servidor

Nela é possível visualizar os dados em uma mapa nacional, com divisões por regiões (Figura 46) e municípios (Figura 47).

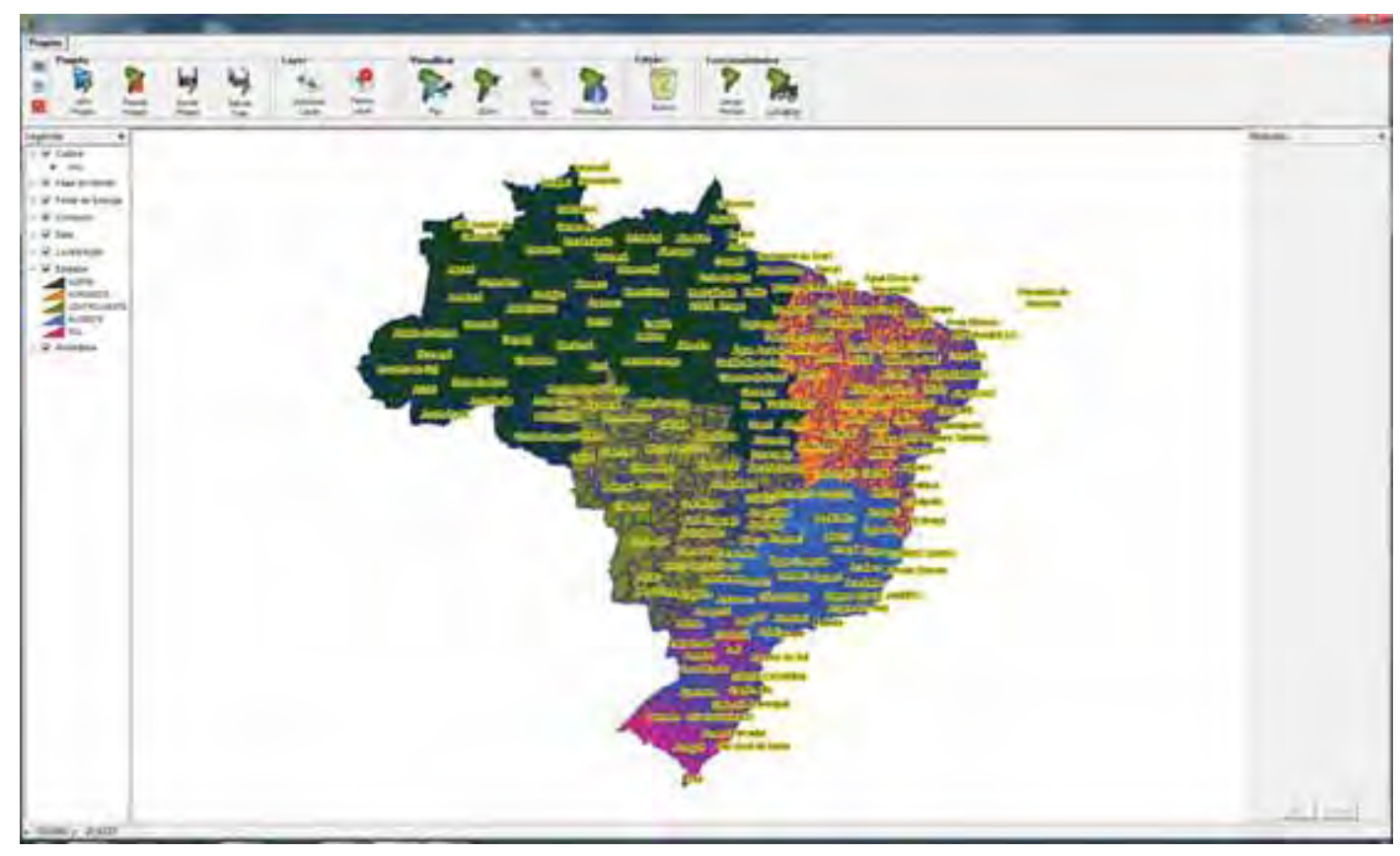

Figura 46: divisão por regiões 


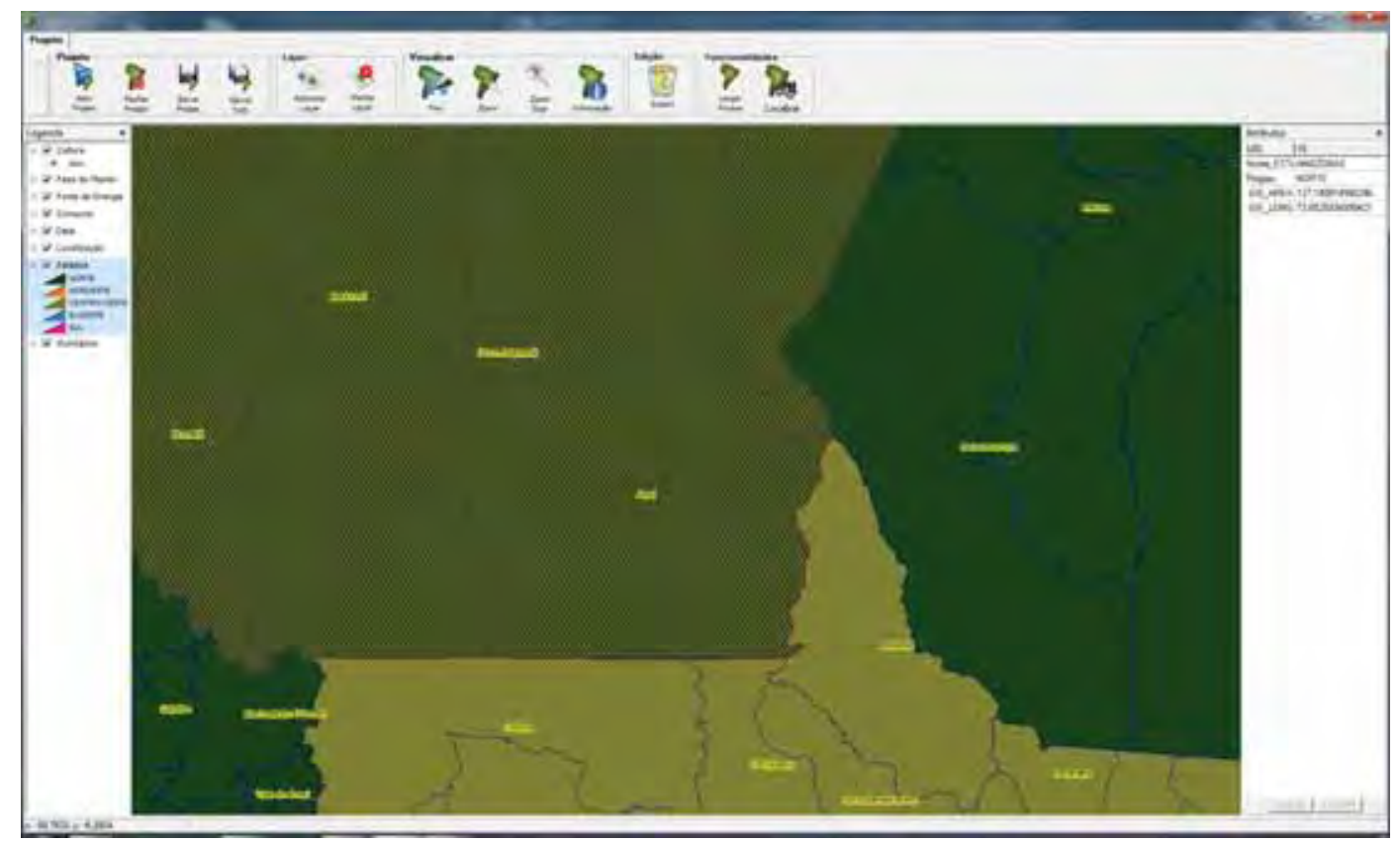

Figura 47: Informações por município.

A qualquer momento é possível consultar informações detalhadas sobre uma região ou realizar a busca no mapa por um município ou região (Figura 51). 


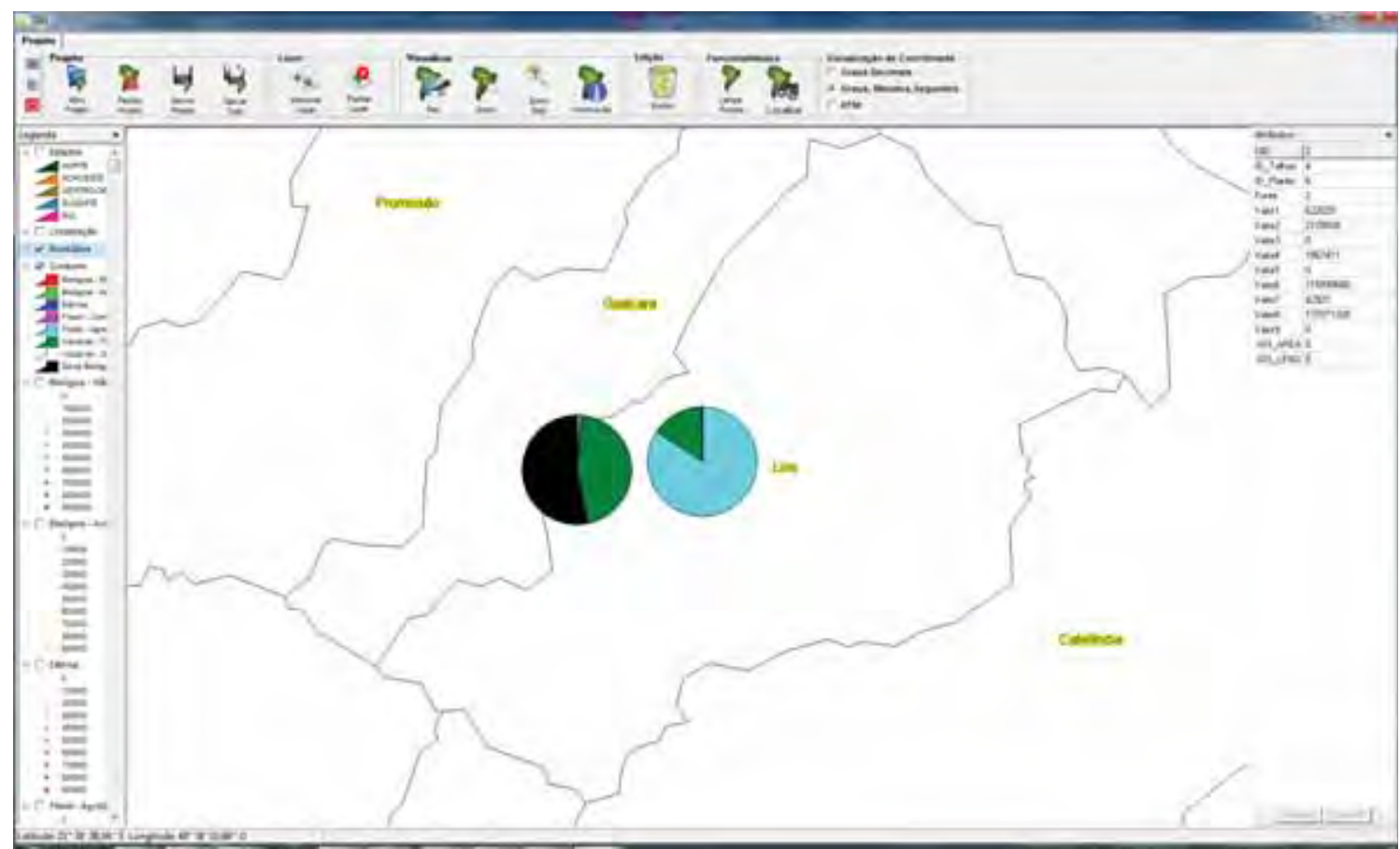

Figura 48: Informações detalhadas sobre uma localidade

O sistema servidor permite ainda uma série de customizações, como definir cores por região (Figura 49), gráficos (Figura 50) e escalas (Figura 51).

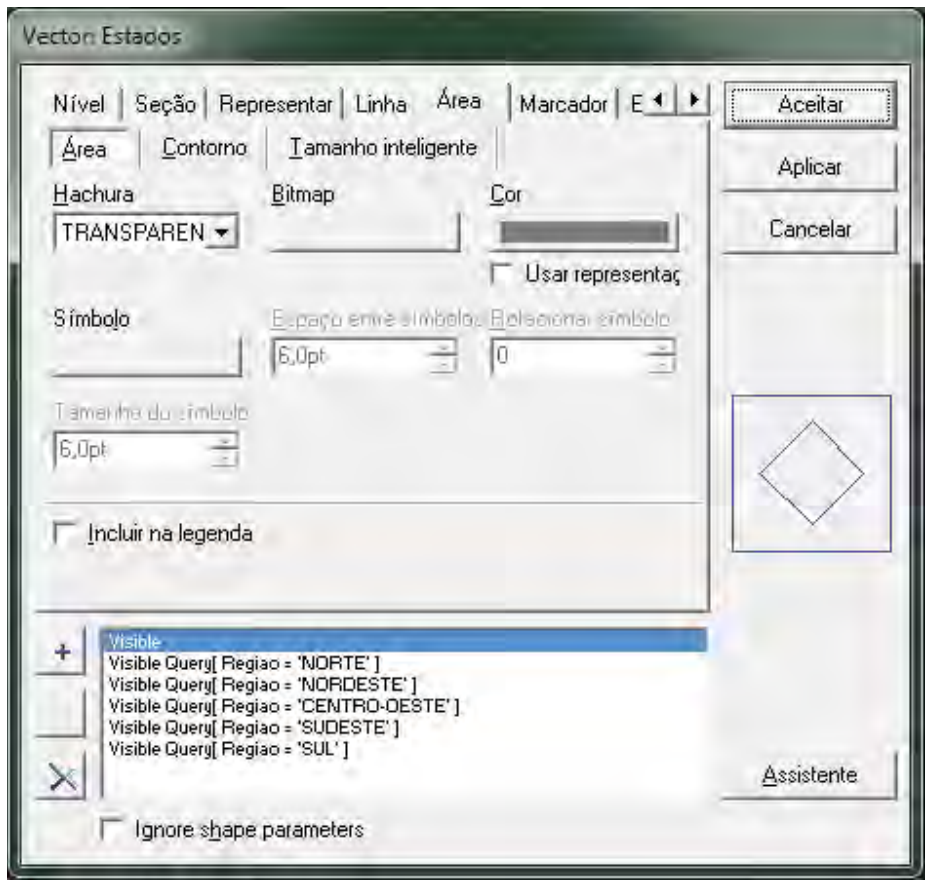

Figura 49: Cores por região 


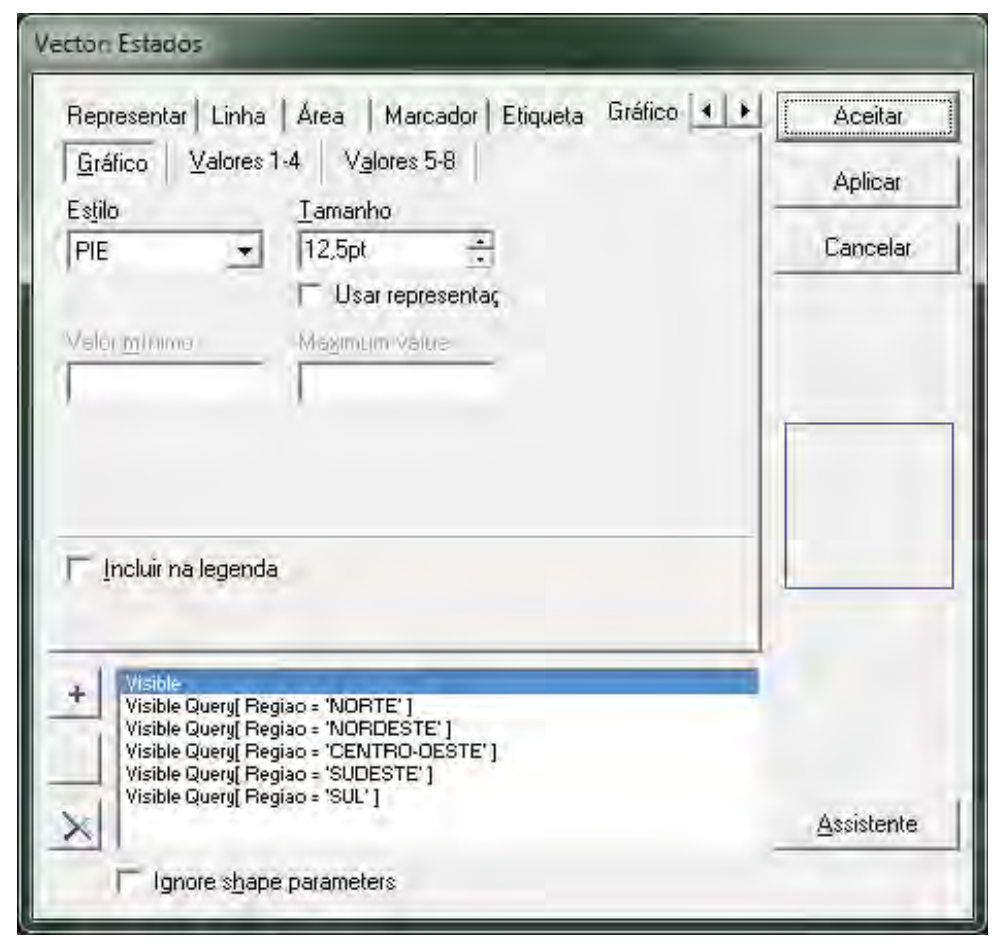

Figura 50: Definições de gráficos

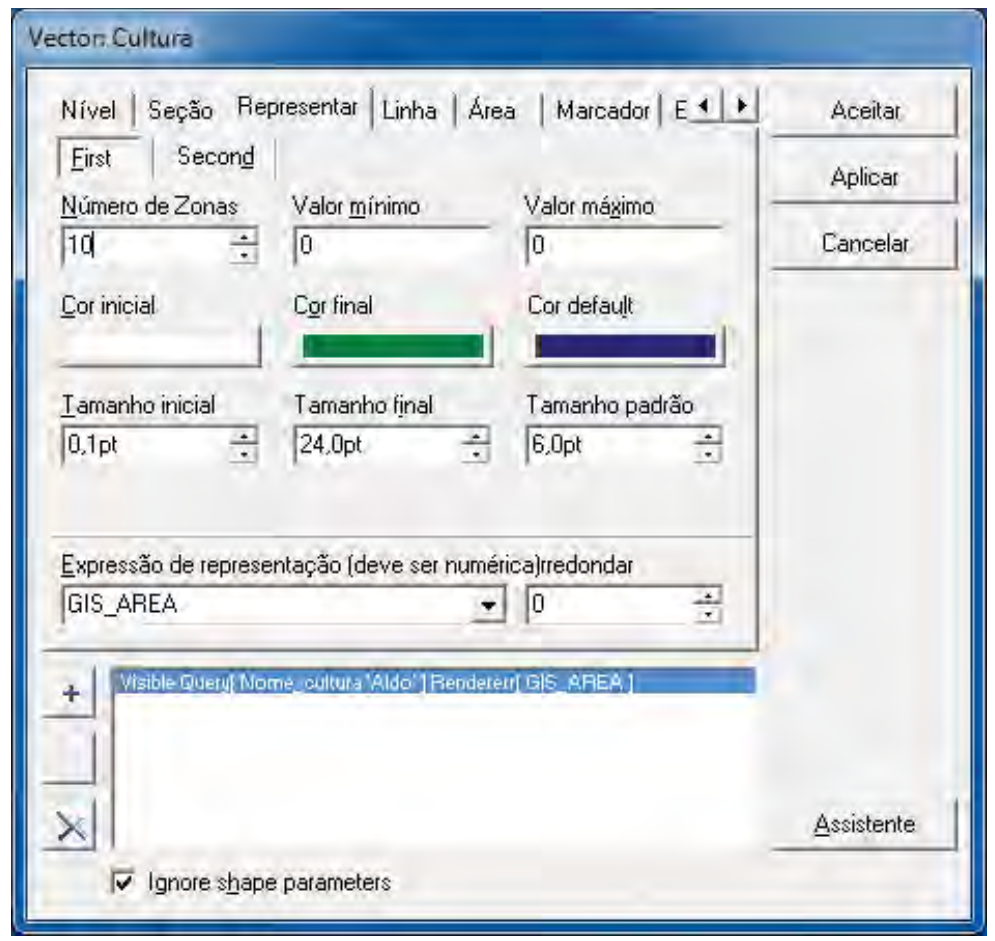

Figura 51: Definição de escalas 
Além de todas as customizações, ele permite exibir ou ocultar atributos, gerar novas consultas (através da linguagem SQL) e salvar as consultas realizadas (Figura 52).

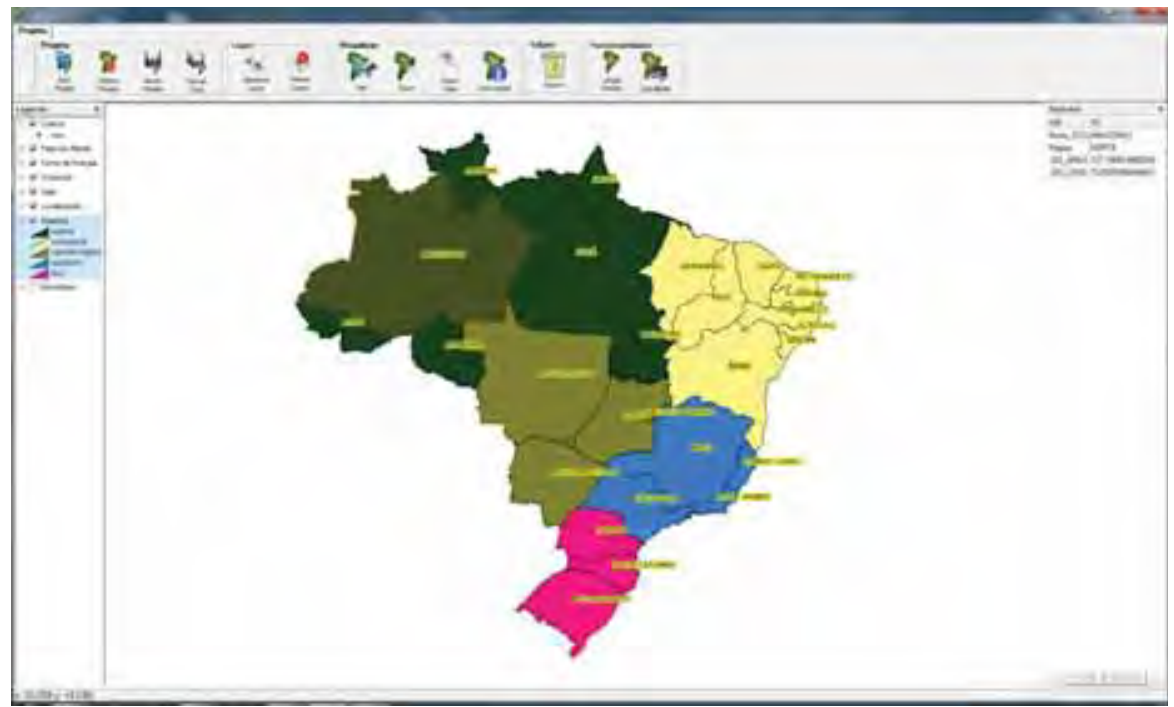

Figura 52: Customização de um mapa 


\section{CONCLUSÕES}

O sistema mostrou-se uma ferramenta muita importante para o auxilio dos pequenos produtores rurais, possuindo vários relatórios gerenciais. Com base nos novos dados, o produtor rural poderá conhecer o desempenho energético do sistema de plantio empregado, podendo, na medida do possível, maximizar os resultados energéticos, melhorando assim a eficiência de todo o sistema de produção.

Com os dados energéticos consolidados, será possível construir um mapeamento energético do Brasil, não apenas de uma região ou cultura, mas de todo o país. Além disso, com o armazenamento dos dados ao longo dos anos, será possível executar uma análise histórica comparativa do desempenho energético de cada propriedade rural ou de uma região, podendo assim mensurar a real eficiência de cada método produtivo.

Como contribuição, este trabalho criou um sistema de análise energética para pequenos empreendimentos rurais, com até 30 hectares, considerando resultados por cultura e disponibilizando dados sobre o consumo energético ao produtor rural, de modo que o mesmo possa compreender e mensurar os gastos energéticos com o sistema de plantio empregado e permita comparar os resultados com outros modelos. Com os dados dos produtores rurais inseridos anualmente, será possível manter um histórico do consumo energético e a sua evolução ao longo dos anos, podendo comparar os resultados e descobrir se uma política pública influenciou ou não os resultados energéticos.

Outra contribuição será a construção do mapa energético rural brasileiro, que até então é desconhecido, e levantar a demanda energética por região e quais culturas demandam maior consumo. 
O modelo implementado considerou várias fontes energéticas (como por exemplo, energia elétrica, humana, fóssil, industrial, etc.), diferente da maioria dos trabalhos realizados, que consideravam, normalmente, a divisão em três grupos (Fóssil, Biológica e Industrial), desconsiderando, em sua grande maioria, o consumo de energia elétrica em um processo produtivo e que, em alguns casos, pode influenciar de maneira significativa os resultados. 


\section{REFERÊNCIAS}

ABC DA ENERGIA. Combustíveis fósseis: petróleo, carvão e gás natural. Disponível em: <http://www.abcdaenergia.com/enervivas/cap05.htm>. Acesso em: 10 jun. 2010.

AGRIBUSINESS. Portal do Agronegócio. Viçosa: 2009. Disponível em: <http://www.portaldoagronegocio.com.br>. Acesso em: 10 dez. 2009.

ASSENHEIMER, A.; CAMPOS, A. T.; GONÇALVES, A. C. Análise energética de produção de soja convencional e orgânica. Ambiência - Revista do setor de Ciências Agrárias e Ambientais, Garapuava, v. 5, n. 3, p. 443-455, set/dez 2009

ASPE. Agência de Serviços Públicos de Energia do Estado do Espírito Santo. Vitória: 2009. Disponível em:<http://www.aspe.es.gov.br/crea-es/index.htm>. Acesso em: 02 mai. 2010.

BEESP. Secretaria de energia, recursos hídricos e saneamento. Balanço energético do Estado de São Paulo 2003: ano base 2002. São Paulo: CESP, 2003. 206 p.

BEN 2009. Balanço Energético Nacional - 2009. Brasília, DF, 2009. Disponível em: <https://ben.epe.gov.br/BENSeriesCompletas.aspx>. Acesso em: 02 mai. 2010.

BEN 2010. Balanço Energético Nacional - 2010. Brasília, DF, 2010. Disponível em: <https://ben.epe.gov.br/BENFornecedores.aspx>. Acesso em 02 mai. 2010. 
BEN 2030. Matriz energética nacional em 2030. Brasília, 2010. Disponível em:

<http://www.mme.gov.br/spe/galerias/arquivos/Publicacoes/matriz_energetica_nacional_2030 /MatrizEnergeticaNacional2030.pdf>. Acesso em: 02 mai. 2010.

BOOCH, G.; RUMBAUGH, J.; JACOBSON, I. UML - Guia do usuário. Rio de Janeiro: Campus, 2005. 472 p.

BRASIL. Ministério de Minas e Energia. Balanço energético nacional. Brasília, DF, 2005. Disponível em:

$<$ http://www.mme.gov.br/site/menu/select_main_menu_item.do?channelId=1432\&pageId=40 60>. Acesso em: 10 ago. 2006.

BRASIL ESCOLA. Energia potencial - Brasil Escola. Goiânia, 2009a. Disponível em: <http://www.brasilescola.com/fisica/energia-potencial.htm>. Acesso em: 13 jul. 2010.

BRASIL ESCOLA. Energia hidrelétrica - Brasil Escola. Goiânia, 2009b. Disponível em: <http://www.brasilescola.com/geografia/energia-hidreletrica.htm>. Acesso em: 13 jul. 2010.

BROWN, D. W.; DUCHANE, D. V. Scientific progress on the Fenton Hill HDR project since 1983. Geothermics, Sicilia, v. 28, n. 4-5, p. 591-601, 1999.

BUENO, O. C.; CAMPOS, A. T.; CAMPOS, A. T. Balanço de energia e contabilização da radiação global: simulação e comparativo. In: Buenos Aires : Facultad de Agronomia, 2000. p. 477-482.

CAMPOS, A. T. et al. Balanço econômico e energético na produção de silagem de milho em sistema intensivo de produção de leite. Engenharia Rural, Piracicaba, v.9, n. 1, p.1-70, jul. 1998.

CASA CIVIL. Lei 10.267 de 28 de agosto de 2001. Brasília, DF: 2001. Disponível em: <http://www.planalto.gov.br/CCIVIL/Leis/LEIS_2001/L10267.htm>. Acesso em: 07 mai. 2010.

CASTANHO FILHO, E. P.; CHABARIBERY, D. Perfil econômico da agricultura paulista. Agricultura em São Paulo, São Paulo, v. 30, n. 2, p. 63-115, 1983. 
COMITRE, V. Avaliação energética e aspectos econômicos da soja na região de Ribeirão Preto, SP. 1993. 152 f. Dissertação (Mestrado em Engenharia Agrícola /Planejamento Agropecuário)-Faculdade de Engenharia Agrícola, Universidade Estadual de Campinas, Campinas, 1993.

DEITEL, HARVEY M.; ,DEITEL, PAUL J. Java: como programar. 6. ed. São Paulo: Prentice-Hall, 2005, 1152 p.

DOERING, O. C. Accounting for energy in farm machinery and buildings. In: PIMENTEL, D. (Ed.). Handbook of energy utilization in agriculture. Boca Raton: CRC Press, 1980. 475 p.

EDUCAR. Conservação da energia mecânica. São Carlos: 2009. Disponível em <http://educar.sc.usp.br/fisica/energiateo.html\#potencial>. Acesso em: 13 jun. 2010.

ENERGIA. Fontes alternativas de energia. Disponível em:

$<$ http://www.portalsaofrancisco.com.br/alfa/meio-ambiente-fontes-alternativas-deenergia/index.php>. Acesso em: 02 mai. 2010

ENERGIA TÉRMICA. Formas de energia. Bom Retiro: 2008. Disponível em:

<http://equipe-estroncio.blogspot.com/2008_11_01_archive.html>. Acesso em: 02 out. 2010.

EÓLICA. A energia eólica. Disponível em: <http://www.abcdaenergia.com/enervivas/ cap10.htm>. Acesso em: 15 jul. 2010.

FLUCK, R. C. Energy sequestered in repairs and maintenance of agricultural machinery. Transactions of the ASAE, Michigan, v. 28, n.3, p.738-744, may/june, 1985.

GEOTERMICA. Energia geotérmica. Disponível em:

<http://www.abcdaenergia.com/enervivas/cap04.htm>. Acesso em: 10 ago.2010.

HART, R. D. Una metodología para analizar sistemas agrícolas en términos energéticos. In: HART, R. D.; JIMÉNEZ, T.; SERPA R. Análisis energético de sistemas agrícolas.

Turrialba: UCR/CATIE, 1980. p. 3-14. 
HESLES, J. B. S. Objetivos e princípios da análise energética, análise de processos

industriais: métodos e convenções. Rio de Janeiro: Preprint AIECOPPE/UFRJ, 1981. 137 p.

HETZ, E. J. Energy utilization in chilean agriculture. Agricultural mechanization in Asia, Africa and Latin America, Tokyo, v. 23, n. 2, p. 52-56, 1992.

INMETRO - INSTITUTO NACIONAL DE METROLOGIA. Sistema internacional de medidas - SI. 8. ed. Rio de Janeiro: INMETRO, 2003. 116 p.

LAUDON, K. C.; LAUDON, J. P. Sistemas de informações gerenciais. São Paulo: Pearson Prentice Hall, 2004. 198 p.

LAUREANO, M. A. P. Informação. Disponível em: $<$ http://www.ppgia.pucpr.br/ laureano/puc_2004/gst/importancia_informacao. html>. Acesso em: 18 fev. 2005.

MELLO, R. Rumo à sustentabilidade da produção de cana-de-açúcar em São Paulo: as contas ambientais. Revista de Administração de Empresas, São Paulo, v. 40, n. 3, p. 74-82, jul/set 2000.

MENDES, J. T. G.; PADILHA JÚNIOR, J. B. Agronegócio: uma abordagem econômica. São Paulo: Pearson Prentice Hall, 2007. 384 p.

OLIVEIRA JR, EZER DIAS. Análise energética de dois sistemas de colheita mecanizada de eucalipto. 2005. $91 \mathrm{f}$. Tese (Doutorado em Recursos Naturais)-Escola Superior de Agricultura Luiz de Queiroz, Universidade de São Paulo, Piracicaba, 2005.

PIMENTEL, D. (Ed.). Handbook of energy utilization in agriculture. Boca Raton: CRC Press, 1980a. 475 p.

PIMENTEL, D. Energy inputs for the production formulation, packaging, and transport of various pesticides. In: PIMENTEL, D. (Ed.) Handbook of energy utilization in agriculture. Boca Raton, Florida: CRC, Press Inc., 1980b. p. 45-48.

PRASS, A. R. Matéria e energia. Porto Alegre, 2009. Disponível em:

<http://www.fisica.net/mecanicaclassica/materia_e_energia.php>. Acesso em: 10 jan. 2010. 
QUESADA, G. M.; BEBER, J. A. C.; SOUZA, S. P. Balanços energéticos uma proposta metodológica para o Rio Grande do Sul. Ciência e Cultura, São Paulo, v. 39, n.1, p. 20-28, 1987.

RISOUD, B. Développement durable et analyse énergétique d'exploitations agricoles. Économie Rurale, Paris, n. 252, p. 16-27, juil-out, 1999.

SIQUEIRA, R.; GAMERO, C. A.; BOLLER, W. Balanço de energia na implantação e manejo de plantas de cobertura do solo. Engenharia Agrícola, Jaboticabal, v. 19, n.1, p. 80-89, 1999.

SEIXAS, F. Avaliação do esforço físico em operadores de motosserra. Série Técnica do IPEF, Piracicaba, v.7, n. 22, p.1-16, jun. 1991.

SOLAR. Energia solar. Disponível em: <http://www.abcdaenergia.com/ enervivas/cap09.htm>. Acesso em: 12 jul. 2010.

SOUZA, C. A.; SACCOL, A. Z. Sistemas ERP no Brasil. São Paulo: Atlas, 2003. 368 p.

TANENBAUM, A. S. Redes de computadores. 3. ed. Rio de Janeiro: Campos, 1997. 927 p.

TANENBAUM, A. S. Sistemas operacionais modernos. 2. ed. São Paulo: Person Prentice Hall, 2003. 712 p.

UML. Fundamentos da UML. Berlin: 2009. Disponível em:

$<$ http://docs.kde.org/stable/pt_BR/kdesdk/umbrello/uml-basics.html>. Acesso em: 10 jun. 2010. 